\title{
California State Waters Map Series-Offshore of Coal Oil Point, California
}

By Samuel Y. Johnson, Peter Dartnell, Guy R. Cochrane, Nadine E. Golden, Eleyne L. Phillips, Andrew C. Ritchie, Rikk G. Kvitek, Bryan E. Dieter, James E. Conrad, Thomas D. Lorenson, Lisa M. Krigsman, H. Gary Greene, Charles A. Endris, Gordon G. Seitz, David P. Finlayson, Ray W. Sliter, Florence L. Wong, Mercedes D. Erdey, Carlos I. Gutierrez, Ira Leifer, Mary M. Yoklavich, Amy E. Draut, Patrick E. Hart, Frances D. Hostettler, Kenneth E. Peters, Keith A. Kvenvolden, Robert J. Rosenbauer, and Grace Fong

(Samuel Y. Johnson and Susan A. Cochran, editors)

Pamphlet to accompany

Scientific Investigations Map 3302 


\title{
U.S. Department of the Interior \\ SALLY JEWELL, Secretary
}

\section{U.S. Geological Survey \\ Suzette M. Kimball, Acting Director}

\author{
U.S. Geological Survey, Reston, Virginia: 2014
}

For more information on the USGS—-the Federal source for science about the Earth, its natural and living resources, natural hazards, and the environment-visit

http://www.usgs.gov or call 1-888-ASK-USGS

For an overview of USGS information products, including maps, imagery, and publications, visit $h$ ttp://www.usgs.gov/pubprod

To order this and other USGS information products, visit $h$ ttp://store.usgs.gov

Suggested citation:

Johnson, S.Y., Dartnell, P., Cochrane, G.R., Golden, N.E., Phillips, E.L., Ritchie, A.C., Kvitek, R.G., Dieter, B.E., Conrad, J.E., Lorenson, T.D., Krigsman, L.M., Greene, H.G., Endris, C.A., Seitz, G.G., Finlayson, D.P., Sliter, R.W. Wong, F.L., Erdey, M.D., Gutierrez, C.I., Leifer, I., Yoklavich, M.M., Draut, A.E., Hart, P.E., Hostettler, F.D., Peters, K.E., Kvenvolden, K.A., Rosenbauer, R.J., and Fong, G. (S.Y. Johnson and S.A. Cochran, eds.), 2014, California State Waters Map Series-Offshore of Coal Oil Point, California: U.S. Geological Survey Scientific Investigations Map 3302, 57 p., 12 sheets, scale 1:24,000, http://dx.doi.org/10.3133/sim3302.

ISSN 2329-132X (online)

Any use of trade, product, or firm names is for descriptive purposes only and does not imply endorsement by the U.S. Government.

Although this report is in the public domain, permission must be secured from the individual copyright owners to reproduce any copyrighted material contained within this report. 


\section{Contents}

Preface

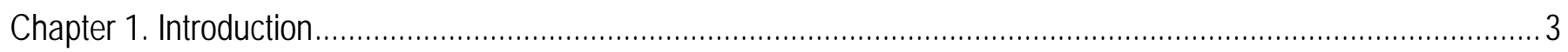

By Samuel Y. Johnson

Publication Summary...

Chapter 2. Bathymetry and Backscatter-Intensity Maps of the Offshore of Coal Oil Point Map Area (Sheets 1, 2, and

3).

By Peter Dartnell and Rikk G. Kvitek

Chapter 3. Data Integration and Visualization for the Offshore of Coal Oil Point Map Area (Sheet 4) .........................12

By Peter Dartnell

Chapter 4. Seafloor-Character Map of the Offshore of Coal Oil Point Map Area (Sheet 5).

By Eleyne L. Phillips, Mercedes D. Erdey, and Guy R. Cochrane

Chapter 5. Ground-Truth Studies for the Offshore of Coal Oil Point Map Area (Sheet 6)

By Nadine E. Golden and Guy R. Cochrane

Chapter 6. Potential Marine Benthic Habitat Map of the Offshore of Coal Oil Point Map Area (Sheet 7)

By H. Gary Greene and Charles A. Endris

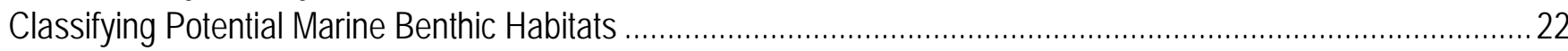

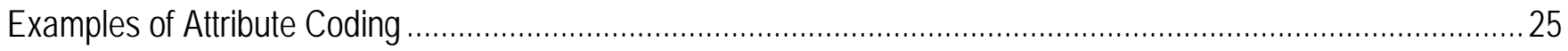

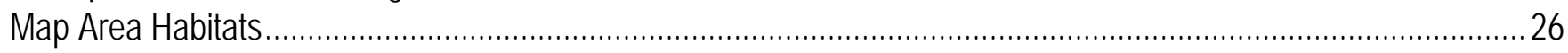

Chapter 7. Subsurface Geology and Structure of the Offshore of Coal Oil Point Map Area and the Santa Barbara

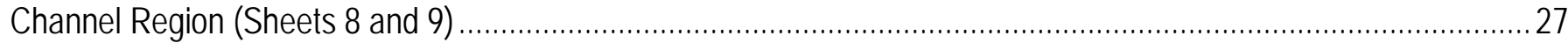

By Samuel Y. Johnson, James E. Conrad, Eleyne L. Phillips, Andrew C. Ritchie, Florence L. Wong,

Ray W. Sliter, Amy E. Draut, and Patrick E. Hart

Data Acquisition

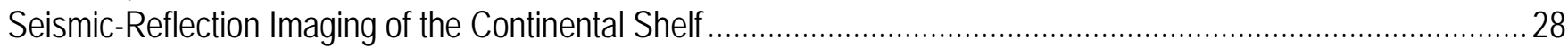

Seismic-Reflection Imaging of the Upper Slope and the Submarine Goleta Landslide Complex .............................29

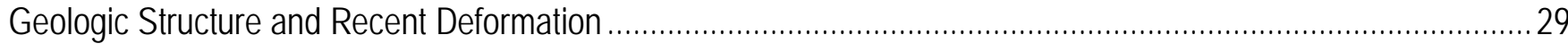

Thickness and Depth to Base of Uppermost Pleistocene and Holocene Deposits ............................................... 30

Chapter 8. Geologic and Geomorphic Map of the Offshore of Coal Oil Point Map Area (Sheet 10)........................... 33

By James E. Conrad, Samuel Y. Johnson, Andrew C. Ritchie, H. Gary Greene, Gordon G. Seitz, and

Carlos I. Gutierrez

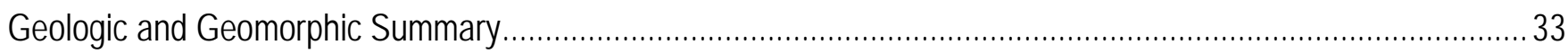

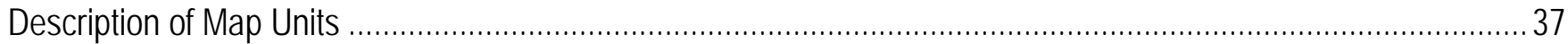

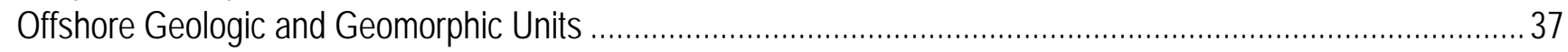

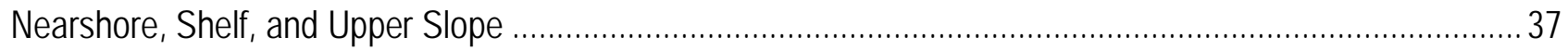

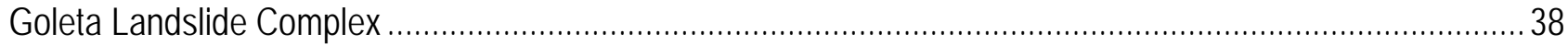

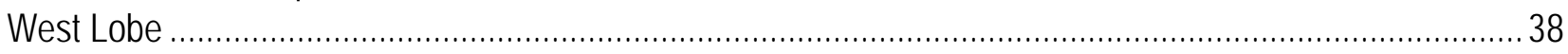

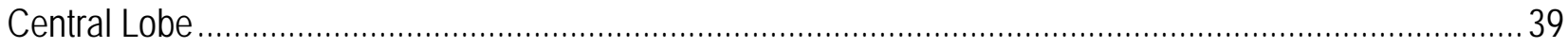

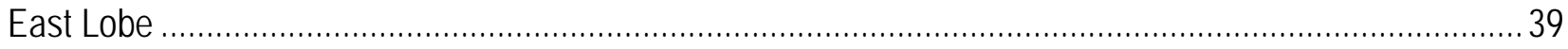

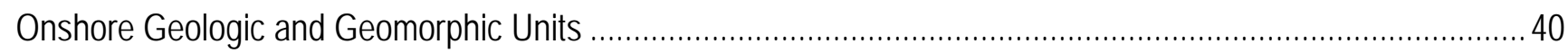

Chapter 9. Natural Offshore Hydrocarbon Seepage and Related Tarball Accumulation in the Offshore of Coal Oil Point Map Area (Sheet 11).

By Thomas D. Lorenson, Florence L. Wong, Ira Leifer, Frances D. Hostettler, Kenneth E. Peters, Keith A. Kvenvolden, Robert J. Rosenbauer, and Grace Fong 
Chapter 10. Predictive Distribution of Benthic Macro-Invertebrates for the Offshore of Coal Oil Point Map Area and the Santa Barbara Channel Region (Sheet 12)...

Acknowledgments

By Lisa M. Krigsman, Mary M. Yoklavich, Nadine E. Golden, and Guy R. Cochrane

References Cited

\section{Figures}

Figure 1-1. Physiography of Santa Barbara Channel region.

Figure 1-2. Coastal geography of Offshore of Coal Oil Point map area ................................................................. 8

Figure 4-1. Detailed view of ground-truth data, showing accuracy-assessment methodology ................................ 16

Figure 5-1. Photograph of camera sled used in USGS 2007 ground-truth survey...

Figure 5-2. Graph showing distribution of primary and secondary substrate determined from video observations in Offshore of Coal Oil Point map area.

Figure 9-1. Chromatograms of selected tarball samples. 46

\section{Tables}

Table 4-1. Conversion table showing how video observations of primary substrate, secondary substrate, and abiotic seafloor complexity are grouped into seafloor-character-map Classes I, II, and III for use in supervised classification and accuracy assessment.....

Table 4-2. Accuracy-assessment statistics for seafloor-character-map classifications.

Table 7-1. Area, sediment-thickness, and sediment-volume data for California's State Waters in Santa Barbara Channel region, as well as in Offshore of Coal Oil Point map area.

Table 8-1. Areas and relative proportions of offshore geologic map units in Offshore of Coal Oil Point map area.... 35

\section{Map Sheets}

Sheet 1. Colored Shaded-Relief Bathymetry, Offshore of Coal Oil Point Map Area, California

By Peter Dartnell, Eleyne L. Phillips, David P. Finlayson, James E. Conrad, and Rikk G. Kvitek

Sheet 2. Shaded-Relief Bathymetry, Offshore of Coal Oil Point Map Area, California

By Peter Dartnell, Eleyne L. Phillips, David P. Finlayson, James E. Conrad, and Rikk G. Kvitek

Sheet 3. Acoustic Backscatter, Offshore of Coal Oil Point Map Area, California

By Peter Dartnell, Eleyne L. Phillips, David P. Finlayson, James E. Conrad, and Rikk G. Kvitek

Sheet 4. Data Integration and Visualization, Offshore of Coal Oil Point Map Area, California

By Peter Dartnell

Sheet 5. Seafloor Character, Offshore of Coal Oil Point Map Area, California

By Eleyne L. Phillips, Mercedes D. Erdey, and Guy R. Cochrane

Sheet 6. Ground-Truth Studies, Offshore of Coal Oil Point Map Area, California

By Nadine E. Golden, Guy R. Cochrane, and Lisa M. Krigsman

Sheet 7. Potential Marine Benthic Habitats, Offshore of Coal Oil Point Map Area, California

By Bryan E. Dieter, H. Gary Greene, Charles A. Endris, Mercedes D. Erdey, and Nadine E. Golden

Sheet 8. Seismic-Reflection Profiles, Offshore of Coal Oil Point Map Area, California

By James E. Conrad, Patrick E. Hart, Ray W. Sliter, Samuel Y. Johnson, Andrew C. Ritchie, Amy E.

Draut, and Eleyne L. Phillips

Sheet 9. Local (Offshore of Coal Oil Point Map Area) and Regional (Offshore from Refugio Beach to Hueneme Canyon) Shallow-Subsurface Geology and Structure, Santa Barbara Channel, California 
By Samuel Y. Johnson, James E. Conrad, Eleyne L. Phillips, Andrew C. Ritchie, Florence L. Wong, Ray W. Sliter, Amy E. Draut, and Patrick E. Hart

Sheet 10. Offshore and Onshore Geology and Geomorphology, Offshore of Coal Oil Point Map Area, California By James E. Conrad, Andrew C. Ritchie, Samuel Y. Johnson, H. Gary Greene, Peter Dartnell, Gordon G. Seitz, and Carlos I. Gutierrez

Sheet 11. Natural Offshore Hydrocarbon Seepage and Related Tarball Accumulation, Offshore of Coal Oil Point Map Area, California

By Thomas D. Lorenson, Florence L. Wong, Ira Leifer, Frances D. Hostettler, Kenneth E. Peters, Keith A, Kvenvolden, Robert J. Rosenbauer, and Grace Fong

Sheet 12. Predicted Distribution of Benthic Macro-Invertebrates, Offshore of Coal Oil Point Map Area and Santa Barbara Channel Region, California

By Lisa M. Krigsman, Mary M. Yoklavich, Guy R. Cochrane, and Nadine E. Golden 


\title{
California State Waters Map Series-Offshore of Coal Oil Point, California
}

\author{
By Samuel Y. Johnson, ${ }^{1}$ Peter Dartnell, ${ }^{1}$ Guy R. Cochrane, ${ }^{1}$ Nadine E. Golden, ${ }^{1}$ Eleyne L. Phillips, ${ }^{1}$ Andrew C. \\ Ritchie, ${ }^{1}$ Rikk G. Kvitek, ${ }^{2}$ Bryan E. Dieter, ${ }^{3}$ James E. Conrad, ${ }^{1}$ Thomas D. Lorenson, ${ }^{1}$ Lisa M. Krigsman, ${ }^{4}$ H. Gary \\ Greene,${ }^{3}$ Charles A. Endris, ${ }^{3}$ Gordon G. Seitz, ${ }^{5}$ David P. Finlayson, ${ }^{1}$ Ray W. Sliter, ${ }^{1}$ Florence L. Wong, ${ }^{1}$ Mercedes \\ D. Erdey, ${ }^{1}$ Carlos I. Gutierrez, ${ }^{5}$ Ira Leifer, ${ }^{6}$ Mary M. Yoklavich, ${ }^{4}$ Amy E. Draut, ${ }^{1}$ Patrick E. Hart, ${ }^{1}$ Frances D. \\ Hostettler, ${ }^{1}$ Kenneth E. Peters, ${ }^{7}$ Keith A, Kvenvolden, ${ }^{1}$ Robert J. Rosenbauer, ${ }^{1}$ and Grace Fong ${ }^{8}$
}

(Samuel Y. Johnson ${ }^{1}$ and Susan A. Cochran, ${ }^{1}$ editors)

\section{Preface}

In 2007, the California Ocean Protection Council initiated the California Seafloor Mapping Program (CSMP), designed to create a comprehensive seafloor map of high-resolution bathymetry, marine benthic habitats, and geology within California's State Waters. The program supports a large number of coastal-zone- and ocean-management issues, including the California Marine Life Protection Act (MLPA) (California Department of Fish and Game, 2008), which requires information about the distribution of ecosystems as part of the design and proposal process for the establishment of Marine Protected Areas. A focus of CSMP is to map California’s State Waters with consistent methods at a consistent scale.

The CSMP approach is to create highly detailed seafloor maps through collection, integration, interpretation, and visualization of swath sonar bathymetric data (the undersea equivalent of satellite remote-sensing data in terrestrial mapping), acoustic backscatter, seafloor video, seafloor photography, high-resolution seismic-reflection profiles, and bottom-sediment sampling data. The map products display seafloor morphology and character, identify potential marine benthic habitats, and illustrate both the surficial seafloor geology and shallow (to about $100 \mathrm{~m}$ ) subsurface geology. It is emphasized that the more interpretive habitat and geology maps rely on the integration of multiple, new high-resolution datasets and that mapping at small scales would not be possible without such data.

This approach and CSMP planning is based in part on recommendations of the Marine Mapping Planning Workshop (Kvitek and others, 2006), attended by coastal and marine managers and scientists from around the state. That workshop established geographic priorities for a coastal mapping project and identified the need for coverage of "lands" from the shore strand line (defined as Mean Higher High Water; MHHW) out to the 3-nautical-mile (5.6-km) limit of California’s State Waters. Unfortunately, surveying the zone from MHHW out to 10-m water depth is not consistently possible using ship-based surveying methods, owing to sea state (for example, waves, wind, or currents), kelp coverage, and

\footnotetext{
${ }^{1}$ U.S. Geological Survey

${ }^{2}$ California State University, Monterey Bay, Seafloor Mapping Lab

${ }^{3}$ Moss Landing Marine Laboratories, Center for Habitat Studies

${ }^{4}$ National Oceanic and Atmospheric Administration, National Marine Fisheries Service

${ }^{5}$ California Geological Survey

${ }^{6}$ University of California, Santa Barbara, Marine Science Institute

${ }^{7}$ Stanford University

${ }^{8}$ CE2 Corporation
} 
shallow rock outcrops. Accordingly, some of the maps presented in this series commonly do not cover the zone from the shore out to 10-m depth; these "no data" zones appear pale gray on most maps.

This map is part of a series of online U.S. Geological Survey (USGS) publications, each of which includes several map sheets, some explanatory text, and a descriptive pamphlet. Each map sheet is published as a PDF file. Geographic information system (GIS) files that contain both ESRI ${ }^{9}$ ArcGIS raster grids (for example, bathymetry, seafloor character) and geotiffs (for example, shaded relief) are also included for each publication. For those who do not own the full suite of ESRI GIS and mapping software, the data can be read using ESRI ArcReader, a free viewer that is available at http://www.esri.com/software/arcgis/arcreader/index.html (last accessed March 15, 2013).

The California Seafloor Mapping Program (CSMP) is a collaborative venture between numerous different federal and state agencies, academia, and the private sector. CSMP partners include the California Coastal Conservancy, the California Ocean Protection Council, the California Department of Fish and Game, the California Geological Survey, California State University at Monterey Bay’s Seafloor Mapping Lab, Moss Landing Marine Laboratories Center for Habitat Studies, Fugro Pelagos, Pacific Gas and Electric Company, National Oceanic and Atmospheric Administration (NOAA, including National Ocean Service - Office of Coast Surveys, National Marine Sanctuaries, and National Marine Fisheries Service), U.S. Army Corps of Engineers, the Bureau of Ocean Energy Management, the National Park Service, and the U.S. Geological Survey.

\footnotetext{
${ }^{9}$ Environmental Systems Research Institute, Inc.
} 


\title{
Chapter 1. Introduction
}

\author{
By Samuel Y. Johnson
}

The map area offshore of Coal Oil Point, California, which is referred to herein as the "Offshore of Coal Oil Point" map area (figs. 1-1, 1-2), lies within the central Santa Barbara Channel region of the Southern California Bight (see, for example, Lee and Normark, 2009). This geologically complex region forms a major biogeographic marine transition zone, separating the cold-temperate Oregonian province north of Point Conception from the warm-temperate California province to the south (Briggs, 1974).

The city of Goleta (population, about 30,000) and the unincorporated community of Isla Vista (population, about 18,000) are the main coastal population centers in the Offshore of Coal Oil Point map area, which also includes the University of California, Santa Barbara (UCSB; enrollment, about 21,000) and the nearby Santa Barbara Municipal Airport (fig. 1-2). The map area forms the western part of a contiguous urban zone (total population, about 220,000) that extends eastward through Santa Barbara to Carpinteria (fig. 1-1). This urbanized coastal zone is situated on the south flank of the east-westtrending Santa Ynez Mountains, on coalescing alluvial fans (bajada) and uplifted marine terraces (elevations as high as about $130 \mathrm{~m}$ ) underlain by folded and faulted Miocene bedrock (Minor and others, 2009). In the Offshore of Coal Oil Point map area, the relatively low-relief, elevated coastal bajada narrows from about $2.5 \mathrm{~km}$ wide in the east to less than $500 \mathrm{~m}$ wide in the west; this westward narrowing coincides with a significant westward decrease in population and development.

Notable recreational beaches and reserves in the Offshore of Coal Oil Point map area include Isla Vista County Park beach, Coal Oil Point Reserve, and Goleta Beach County Park (fig. 1-2). Goleta Beach County Park, which includes the approximately 440-m-long recreational Goleta Pier, fronts the large estuary, tidal marsh, and wetlands of the Goleta Slough. The Coal Oil Point Reserve (managed by UCSB) protects a wide variety of coastal strand and estuarine habitats, including the seasonally flooded tidal lagoon of Devereux Lagoon.

The Offshore of Coal Oil Point map area lies in the central part of the Santa Barbara littoral cell (fig. 1-1), which is characterized by west-to-east transport of sediment from Point Arguello on the northwest to Hueneme and Mugu Canyons on the southeast (see, for example, Griggs and others, 2005; Hapke and others, 2006). On the basis of harbor dredging records, Griggs and others (2005) reported east-southeast longshore drift rates that range from about 160,000 to 800,000 tons/yr, averaging 400,000 tons/yr. At the east end of the littoral cell, eastward-moving sediment is trapped by Hueneme and Mugu Canyons (fig. 1-1) and then transported down these canyons into the deep-water Santa Monica Basin (Normark and others, 2009).

Sediment supply to the western and central part of the littoral cell is mainly from relatively small transverse coastal watersheds, which have an estimated cumulative annual sediment flux of 640,000 tons/yr between Point Arguello and the Ventura River (Warrick and Farnsworth, 2009). Within the Offshore of Coal Oil Point map area, these coastal watersheds include (from west to east) Las Llagas Canyon, Gato Canyon, Las Varas Canyon, Dos Pueblos Canyon, Eagle Canyon, Tecolote Canyon, Winchester Canyon, Ellwood Canyon, Glen Annie Canyon, and San Jose Creek (fig. 1-2). The much larger Santa Ynez River (which drains the north flank of the Santa Ynez Mountains) and the Santa Maria River, the mouths of which are about 100 to $140 \mathrm{~km}$ northwest of the map area (fig. 1-1), are not considered to be significant sediment sources because Point Conception and Point Arguello provide obstacles to downcoast sediment transport and also because, at present, much of their sediment load is trapped in dams (Griggs and others, 2005). In addition, the much larger Ventura and Santa Clara Rivers, the mouths of which lie 45 to $55 \mathrm{~km}$ southeast of the map area (fig. 1-1), have high sediment yields (Warrick and Farnsworth, 2009); however, these are located downdrift from Coal Oil Point and, thus, are not considered to be significant sediment sources for the map area. River and stream discharge and 
sediment load in the small, transverse coastal watersheds are highly variable, characterized by brief large events during major winter storms and long periods of low (or no) flow and minimal sediment load between storms. In recent history, the majority of high-discharge, high-sediment-flux events have been associated with El Niño phases of the El Niño-Southern Oscillation (ENSO) climatic pattern (Warrick and Farnsworth, 2009).

Much of the coast in the Coal Oil Point map area is characterized by uplifted marine terraces, cliffs, and narrow beaches that have thin sediment (sand and pebble) cover. Notably, a boulder delta has formed at the mouth of Gato Canyon (Griggs and others, 2005). The beaches are subject to erosion each winter during storm-wave attack, and then they undergo gradual recovery or accretion during the more gentle wave climate of the late spring, summer, and fall months. Hapke and others (2006) suggested that essentially no change has happened to most of the beaches in the map area since the mid- to late 1800s. The area around Isla Vista (and just northwest of it), however, has experienced high short-term erosion rates, locally exceeding $2 \mathrm{~m} / \mathrm{yr}$. Hapke and Reid (2007) indicated that coastal bluffs in the map area are eroding at a rate of about $0.2 \mathrm{~m} / \mathrm{yr}$. As with stream discharge and sediment flux, coastal erosion has been most acute during El Niño phases of the ENSO climatic pattern.

Within California's State Waters, the Offshore of Coal Oil Point map area consists of relatively flat (about $0.8^{\circ}$ to $1.0^{\circ}$ and shallow continental shelf. The shelf break, at a depth of about $90 \mathrm{~m}$, is roughly coincident with the 3-nautical-mile $(5.6-\mathrm{km})$ limit of State Waters. This part of the Southern California Bight is relatively well protected from large Pacific swells from the north and northwest by Point Conception and from south and southwest swells by offshore islands and banks (O'Reilly and Guza, 1993). Fair-weather wave base is typically shallower than 20-m water depth, but winter storms are capable of resuspending fine-grained sediments in $30 \mathrm{~m}$ of water (Xu and Noble, 2009, their table 7), and so shelf sediments in the map area probably are remobilized on an annual basis. As with sediment discharge from rivers, the largest wave events and the highest sediment transport rates on the shelf are typically associated with ENSO events. The shelf is underlain by variable amounts (0 to $20 \mathrm{~m}$ ) of upper Quaternary marine and fluvial sediments deposited as sea level fluctuated in the late Pleistocene (see sheets 8 and 9 of this report; see also, Slater and others, 2002; Draut and others, 2009).

Several submarine landslides have been documented along the shelf break on the south edge of California's State Waters, in the southern part of the map area (Fisher and others, 2005; Greene and others, 2006; Lee and others, 2009). The largest $\left(130 \mathrm{~km}^{2}\right)$ is the Goleta landslide complex (fig. 1-1), a compound slump complex that is inferred to have been initiated more than 200,000 years ago but that also includes three recent failures thought to have been generated sometime between 8,000 to 10,000 years ago (Greene and others, 2006). Modeling of the smaller lobes of the Goleta landslide complex indicates that a local, 5- to 10-m-high tsunami may have been generated from these failure events (Greene and others, 2006). The much smaller (about $4 \mathrm{~km}^{2}$ ) Gaviota landslide, located on the slope about $8 \mathrm{~km}$ west of the Goleta landslide complex (fig. 1-1), may have failed as recently as 300 years ago (Lee and others, 2004) or later (200 years ago), and it has been proposed as the cause of a local tsunami in 1812.

The potential marine benthic habitat types mapped in the Offshore of Coal Oil Point map area are directly related to its Quaternary geologic history, geomorphology, and active sedimentary processes. These potential habitats lie primarily within the Shelf (continental shelf) but also partly within the Flank (basin flank or continental slope) megahabitats of Greene and others (2007). The continental shelf, formed by erosion and deposition during sea-level fluctuations over the last several hundred thousand years, is made up primarily of unconsolidated sand and mud, with bedrock exposed in both the nearshore and outer parts of the shelf. Parts of the outer shelf underlain by sediment notably include abundant pockmarks and associated carbonate mounds. The fairly homogeneous sedimentary seafloor provides promising habitat for groundfish, crabs, shrimp, and other marine benthic organisms, 
whereas bedrock outcrops and carbonate mounds are potential benthic habitats for rockfish (Sebastes spp.) and other groundfish that forage and seek refuge in such habitats.

The Offshore of Coal Oil Point map area is in the Ventura Basin, in the southern part of the Western Transverse Ranges geologic province, which is north of the California Continental Borderland $^{10}$ (Fisher and others, 2009). Significant clockwise rotation—at least $90^{\circ}$ — since the early Miocene has been proposed for the Western Transverse Ranges province (Luyendyk and others, 1980; Hornafius and others, 1986; Nicholson and others, 1994), and this region is presently undergoing northsouth shortening (see, for example, Larson and Webb, 1992). In the eastern part of the map area, cross sections suggest that this shortening is, in part, accommodated by offset on the North Channel, Red Mountain, South Ellwood, and More Creek Fault systems (Bartlett, 1998; Heck, 1998; Redin and others, 2005; Leifer and others, 2010). Crustal deformation in the western part of the Offshore of Coal Oil Point map area apparently is less complex than that in the eastern part (Redin, 2005); the western structure is dominated by a large, south-dipping homocline that extends from the south flank of the Santa Ynez Mountains beneath the continental shelf.

Further evidence of active crustal deformation comes from uplifted, onland marine terraces. Keller and Gurrola (2000) and Gurrola and others (2014) mapped six or more such terraces in the Goleta area, which range in elevation from less than 25 to $130 \mathrm{~m}$, that are inferred to have formed during marine oxygen-isotope stages 5 (about 80,000 to 120,000 years ago) and 3 (about 29,000 to 57,000 years ago) (Muhs and others, 1992, 2004). The presence of exposed oxygen-isotope stage 3 terraces, uncommon along the California coast, requires rapid uplift. Uplift rates that are based on marine-terrace elevation and geochronology are estimated to be in the range of 1.6 to $2.0 \mathrm{~mm} / \mathrm{yr}$ from the eastern map margin to Coal Oil Point (Gurrola and others, 2014), but they may drop to about $0.4 \mathrm{~mm} / \mathrm{yr}$ near Naples in the western part of the map area (Metcalf, 1994).

The Offshore of Coal Oil Point map area has had a long history of hydrocarbon development, which began in 1928 with discovery of the Ellwood oil field (Galloway, 1997, 1998) that crosses the shoreline west of Coal Oil Point (fig. 1-2). Subsequent discoveries in the offshore part of the map area include the South Ellwood offshore oil field, the Coal Oil Point oil field, and the Naples oil and gas field (Barnum, 1998; Brickey, 1998; Galloway, 1998). Oil and gas are sourced mainly by the Miocene Monterey Formation, with reservoirs in the Oligocene Vaqueros Formation, the Miocene Rincon Shale and the Miocene Monterey Formation. Development of the South Ellwood offshore field began in 1966 from platform "Holly" (fig. 1-2), which was the last platform to be installed in California's State Waters. Numerous directionally drilled oil wells now originate at platform "Holly," and several pipelines connect the platform to an onshore oil-processing facility. The approximately 430-m-long Ellwood Pier, located between the mouths of Eagle and Tecolote Canyons (fig. 1-2), serves as a terminal for offshore hydrocarbon development. This pier and its associated onland infrastructure gained notoriety as the first mainland site in the United States to be shelled by Japanese submarines in World War II (Galloway, 1998).

The area is known for "the world's most spectacular marine hydrocarbon seeps" (Hornafius and others, 1999), and large tar seeps are exposed on beaches east of the mouth of Goleta Slough (fig. 1-2). Offshore seeps adjacent to the South Ellwood oil field release about 40 tons per day of methane and about 19 tons per day of reactive organic gas (that is, ethane, propane, butane, and higher hydrocarbons), about twice the mass of hydrocarbons released by on-road vehicle traffic in Santa Barbara County in 1990 (Hornafius and others, 1999). The seeps produce a slick on the sea surface that can be many kilometers long, as well as tarballs resulting from oil degradation, evaporation, and weathering.

\footnotetext{
${ }^{10}$ The California Continental Borderland is defined as the complex continental margin that extends from Point Conception south into northern Baja California.
} 


\section{Publication Summary}

This publication about the Offshore of Coal Oil Point map area includes twelve map sheets that contain explanatory text, in addition to this descriptive pamphlet and a data catalog of geographic information system (GIS) files. Sheets 1, 2, and 3 combine data from six different sonar surveys to generate comprehensive high-resolution bathymetry and acoustic-backscatter coverage of the map area. These data reveal a range of physiographic features (highlighted in the perspective views on sheet 4) such as the flat, sediment-covered Santa Barbara shelf interspersed with tectonically controlled bedrock uplifts, nearshore depositional bars, and the headwall of the submarine Goleta landslide complex. To validate the geological and biological interpretations of the sonar data shown on sheets 1 , 2, and 3 , the U.S. Geological Survey towed a camera sled over specific offshore locations, collecting both video and photographic imagery; this "ground-truth" surveying data is summarized on sheet 6 . Sheet 5 is a "seafloor character" map, which classifies the seafloor on the basis of depth, slope, rugosity (ruggedness), and backscatter intensity and which is further informed by the ground-truth-survey imagery. Sheet 7 is a map of "potential habitats," which are delineated on the basis of substrate type, geomorphology, seafloor process, or other attributes that may provide a habitat for a specific species or assemblage of organisms. Sheet 8 compiles representative seismic-reflection profiles from the map area, providing information on the subsurface stratigraphy and structure of the map area. Sheet 9 shows the distribution and thickness of young sediment (deposited over the last about 21,000 years, during the most recent sea-level rise) in both the map area and the larger Santa Barbara Channel region (offshore from Refugio Beach to Hueneme Canyon), interpreted on the basis of the seismic-reflection data. Sheet 10 is a geologic map that merges onshore geologic mapping (compiled from existing maps by the California Geological Survey) and new offshore geologic mapping that is based on the integration of high-resolution bathymetry and backscatter imagery (sheets 1, 2, 3), seafloor-sediment and rock samples (Reid and others, 2006), digital camera and video imagery (sheet 6), and high-resolution seismicreflection profiles (sheet 8). Sheet 11 is a compilation of known hydrocarbon-seepage sites and their oilsource chemical fingerprinting, the results of a 10-year study that linked beach tarballs to their offshore sources. Sheet 12 uses the ground-truth-survey imagery to develop a statistical model and maps that predict the distribution of benthic macro-invertebrates for both the Offshore of Coal Oil Point map area and the Santa Barbara Channel region.

The information provided by the map sheets, pamphlet, and data catalog have a broad range of applications. High-resolution bathymetry, acoustic backscatter, ground-truth-surveying imagery, habitat mapping, and maps of predicted species distribution all contribute to habitat characterization and ecosystem-based management by providing essential data for delineation of marine protected areas and ecosystem restoration. Many of the maps provide high-resolution baselines that will be critical for monitoring environmental change associated with climate change, coastal development, or other forcings. High-resolution bathymetry is a critical component for modeling coastal flooding caused by storms and tsunamis, as well as inundation associated with longer term sea-level rise. Seismic-reflection and bathymetric data help characterize earthquake and tsunami sources, critical for natural-hazard assessments of coastal zones. Information on sediment distribution and thickness is essential to the understanding of local and regional sediment transport, as well as the development of regional sedimentmanagement plans. Documentation of hydrocarbon seepage and tarball accumulation is critical for distinguishing "natural” from anthropogenic pollution. Siting of any new offshore infrastructure (for example, pipelines, cables, or renewable-energy facilities) will depend on high-resolution mapping. Finally, this mapping will both stimulate and enable new scientific research and also raise public awareness of, and education about, coastal environments and issues. 


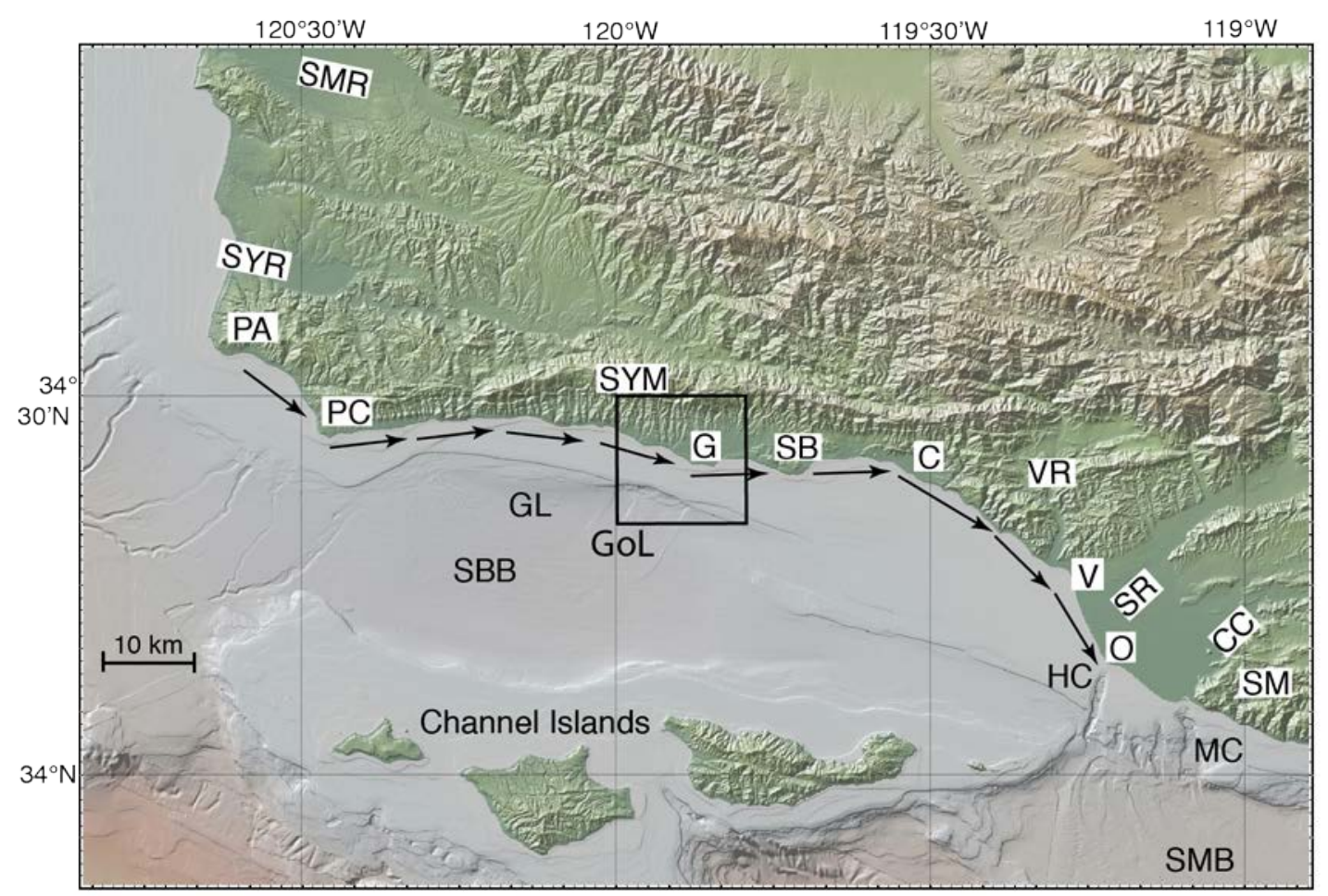

Figure 1-1. Physiography of Santa Barbara Channel region. Box shows Offshore of Coal Oil Point map area. Arrows show direction of sediment transport in Santa Barbara littoral cell, which extends from Point Arguello (PA) to Hueneme Canyon ( $\mathrm{HC}$ ) and Mugu Canyon (MC). Other abbreviations: C, Carpinteria; CC, Calleguas Creek; G, Goleta; GL, Gaviota landslide; GoL, Goleta landslide complex; O, Oxnard; PC, Point Conception; SB, Santa Barbara; SBB, Santa Barbara Basin; SM, Santa Monica Mountains; SMB, Santa Monica Basin; SMR, Santa Maria River; SR, Santa Clara River; SYM, Santa Ynez Mountains; SYR, Santa Ynez River; V, Ventura; VR, Ventura River. 


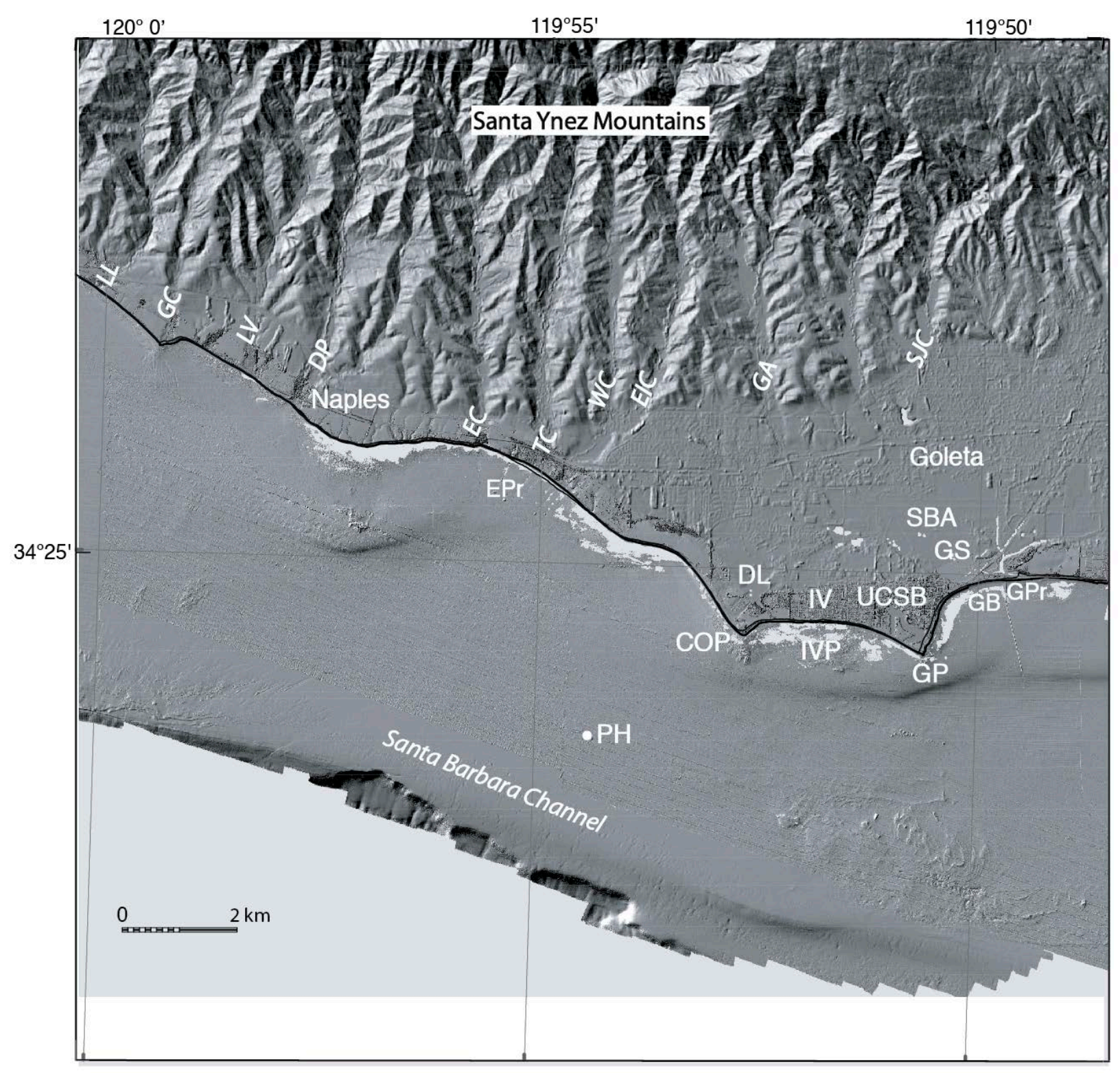

Figure 1-2. Coastal geography of Offshore of Coal Oil Point map area. Abbreviations: COP, Coal Oil Point; DL, Devereaux Lagoon and Coal Oil Point Reserve; DP, Dos Pueblos Canyon; EC, Eagle Canyon; EIC, Ellwood Canyon; EPr, Ellwood Pier; GA, Glen Annie Canyon; GB, Goleta Beach County Park; GC, Gato Canyon; GP, Goleta Point; GPr, Goleta Pier; GS, Goleta Slough; IV, Isla Vista; IVP, Isla Vista County Park; LV, Las Varas Canyon; LL, Las Llagas Canyon; PH, platform "Holly;" SBA, Santa Barbara Municipal Airport; SJC, San Jose Creek; TC, Tecolote Canyon; WC, Winchester Canyon; UCSB, University of California, Santa Barbara. 


\title{
Chapter 2. Bathymetry and Backscatter-Intensity Maps of the Offshore of Coal Oil Point Map Area (Sheets 1, 2, and 3)
}

\author{
By Peter Dartnell and Rikk G. Kvitek
}

The colored shaded-relief bathymetry (sheet 1), the shaded-relief bathymetry (sheet 2), and the acoustic-backscatter (sheet 3) maps of the Offshore of Coal Oil Point map area in southern California were generated from bathymetry and backscatter data collected by the U.S. Geological Survey (USGS), by California State University, Monterey Bay (CSUMB), and by Fugro Pelagos (fig. 1 on sheets 1, 2, 3). Most of the nearshore and shelf areas were mapped by the USGS in the summers of 2006, 2007, and 2008, using a combination of 117-kHz and 234.5-kHz SEA (AP) Ltd. SWATHplus-M phasedifferencing sidescan sonars. A small area in the far-eastern nearshore and shelf was mapped by CSUMB in the summer of 2007, using a 244-kHz Reson 8101 multibeam echosounder. The outer shelf and slope were mapped by Fugro Pelagos in 2008, using a combination of 400-kHz Reson 7125, 240kHz Reson 8101, and 100-kHz Reson 8111 multibeam echosounders. In addition, the nearshore bathymetry and coastal topography were mapped by Fugro Pelagos in 2009 for the U.S. Army Corps of Engineers (USACE) Joint Lidar Bathymetry Technical Center of Expertise, using the SHOALS-1000T bathymetric-lidar and Leica ALS60 topographic-lidar systems. All of these mapping missions combined to collect bathymetry (sheets 1,2 ) from the 0 -m isobath to beyond the 3-nautical-mile limit of California's State Waters, as well as acoustic-backscatter data (sheet 3) from about the 10-m isobath to beyond the 3-nautical-mile limit.

During the USGS mapping missions, differential GPS (DGPS) data (2006, 2007) and GPS data with real-time kinematic corrections (2008) were combined with measurements of vessel motion (heave, pitch, and roll) in a CodaOctopus F180 attitude-and-position system to produce a high-precision vesselattitude packet. This packet was transmitted to the acquisition software in real time and combined with instantaneous sound-velocity measurements at the transducer head before each ping. The returned samples were projected to the seafloor using a ray-tracing algorithm that works with previously measured sound-velocity profiles. Statistical filters were applied to discriminate seafloor returns (soundings and backscatter intensity) from unintended targets in the water column. Finally, the soundings were converted into 2-m-resolution bathymetric-surface-model grids. The backscatter data were postprocessed using USGS software (D.P. Finlayson, written comm., 2011) that normalizes for time-varying signal loss and beam-directivity differences. Thus, the raw 16-bit backscatter data were gain-normalized to enhance the backscatter of the SWATHplus system. The resulting normalizedamplitude values were rescaled to 16-bit and gridded into GeoJPEGs using GRID Processor Software, then imported into a geographic information system (GIS) and converted to GRIDs.

During both the CSUMB and the 2008 Fugro Pelagos multibeam mapping missions, an Applanix POS MV (Position and Orientation System for Marine Vessels) was used to accurately position the vessels during data collection, and it also accounted for vessel motion such as heave, pitch, and roll (position accuracy, $\pm 2 \mathrm{~m}$; pitch, roll, and heading accuracy, $\pm 0.02^{\circ}$; heave accuracy, $\pm 5 \%$, or $5 \mathrm{~cm}$ ). To account for tidal-cycle fluctuations, CSUMB used NavCom 2050 GPS receiver (CNAV) data, and Fugro Pelagos used KGPS data (GPS data with real-time kinematic corrections). In addition, sound-velocity profiles were collected with an Applied Microsystems (AM) SVPlus sound velocimeter. Soundings were corrected for vessel motion using the Applanix POS MV data, for variations in water-column sound velocity using the AM SVPlus data, and for variations in water height (tides) using vertical-position data from the CNAV receiver and also the KGPS data (Kvitek, 2007). Most soundings in the Offshore of Coal Oil Point map area were converted to 2-m-resolution bathymetric-surface-model grids; however, soundings along the outer shelf and slope in water depths greater than $80 \mathrm{~m}$ were converted to a 
5-m-resolution bathymetric-surface-model grid because of lower sounding density. Backscatter data were postprocessed using both Geocoder version 3.2 (Fugro Pelagos modified test release 16) and Geocoder within Caris HIPS and SIPS software. Georeferenced Backscatter Rasters (GeoBaRs) were created for each survey line using the beam average or time series data type. Intensities were radiometrically corrected (including despeckling and angle-varying gain adjustments), and the position of each acoustic sample was geometrically corrected for slant range on a line-by-line basis. The contrast and brightness of some GeoBaRs were adjusted to better match the surrounding GeoBaRs. Individual GeoBaRs were mosaicked together at 2-m resolution using the auto-seam method. The mosaics were then exported as georeferenced TIFF images, imported into a GIS, and converted to GRIDs.

During the 2009 Fugro Pelagos coastal airborne-lidar mapping mission that was completed as part of the National Coastal Mapping Program of USACE, the Leica ALS60 topographic-lidar and the SHOALS-1000T bathymetric-lidar systems were mounted on an aircraft that flew survey lines at an altitude of 300 to $400 \mathrm{~m}$ (bathymetry) and 300 to 1,200 m (topography), at speeds of between 135 and 185 knots. The ALS60 system collected data at a maximum pulse rate of $200 \mathrm{kHz}$, and the SHOALS system collected data at $1 \mathrm{kHz}$. Information on aircraft position, velocity, and acceleration were collected using the Novatel and POS A/V 410 systems (SHOALS) and the onboard GPS/IMU system (ALS60). Aircraft-position data were processed using POSPac software, and the results were combined with the lidar data to produce 3-D positions for each lidar shot. Various commercial and proprietary software packages were used to clean the data, to convert all valid data from ellipsoid to orthometric heights, and to export the data as a series of topography and bathymetry ASCII files.

Soundings from the different mapping missions were converted into bathymetric-surface-model grids: the individual 2-m-resolution surface models were merged into one overall 2-m-resolution bathymetric-surface model and clipped to the boundary of the map area; the 5-m-resolution bathymetricsurface model was processed as a separate grid. Difference calculations of the overlapping bathymetry grids showed that there is good agreement between surveys, even though the surveys were conducted at different times using different mapping equipment. For example, a mean difference of $0.12 \mathrm{~m}$ ( 0.41 standard deviation) exists between the 2006 USGS SWATHplus data and the overlapping 2009 USACE bathymetric-lidar data, even though the overlap is in the energetic nearshore region that is highly susceptible to natural change. A mean difference of $0.49 \mathrm{~m}$ (0.33 standard deviation) also is present between the 2007 CSUMB multibeam-echosounder data and the 2006 USGS SWATHplus data in the far-eastern part of the map area.

An illumination having an azimuth of $300^{\circ}$ and from $45^{\circ}$ above the horizon was then applied to the 2-m and 5-m bathymetric surfaces to create the shaded-relief imagery (sheets 1,2 ). In addition, a modified "rainbow" color ramp was applied to the bathymetry data for sheet 1 , using reds and oranges to represent shallower depths, and dark blues and purples to represent greater depths. This colored bathymetry surface was draped over the shaded-relief imagery at 60-percent transparency to create a colored shaded-relief map (sheet 1). Note that the ripple patterns and straight lines that are apparent within the map area are data-collection artifacts. In addition, lines at the borders of some surveys are the result of slight differences in depth, as measured by different mapping systems in different years. These various artifacts are made obvious by the hillshading process.

Bathymetric contours (sheets 1, 2, 3, 7, 10,11) were generated from a modified bathymetric surface of California's State Waters within the Santa Barbara Channel. This surface was generated by merging all of California Seafloor Mapping Program's bathymetry data for the region into one surface model. After merging, the surface model was resampled to 10-m resolution, and then a smooth arithmetic mean convolution function that assigns a weight of one-ninth to each cell in a 3-pixel by 3-pixel matrix was applied iteratively to the surface ten times. Following smoothing, contour lines were generated at $10-\mathrm{m}$ intervals, from -10 to $-100 \mathrm{~m}$, and at 50-m intervals, from -100 to $-250 \mathrm{~m}$, then the contours were clipped to the boundary of the map area. 
The acoustic-backscatter imagery from each different mapping system and processing method were merged into their own individual grids. These individual grids, which cover different areas, were displayed in a GIS to create a composite acoustic-backscatter map (sheet 3). On the map, brighter tones indicate higher backscatter intensity, and darker tones indicate lower backscatter intensity. The intensity represents a complex interaction between the acoustic pulse and the seafloor, as well as characteristics within the shallow subsurface, providing a general indication of seafloor texture and sediment type. Backscatter intensity depends on the acoustic source level; the frequency used to image the seafloor; the grazing angle; the composition and character of the seafloor, including grain size, water content, bulk density, and seafloor roughness; and some biological cover. Harder and rougher bottom types such as rocky outcrops or coarse sediment typically return stronger intensities (high backscatter, lighter tones), whereas softer bottom types such as fine sediment return weaker intensities (low backscatter, darker tones). The differences in backscatter intensity that are apparent in some areas on sheet 3 are due to the different frequencies of mapping systems, as well as different processing techniques. Note also that the straight lines of higher backscatter intensity that are visible throughout the map area are data-collection artifacts.

The onshore-area image was generated by applying an illumination having an azimuth of $300^{\circ}$ and from $45^{\circ}$ above the horizon to the coastal airborne topographic-lidar data, as well as to publicly available, 3-m-resolution, interferometric synthetic aperture radar (ifSAR) data, available from National Oceanic and Atmospheric Administration (NOAA) Coastal Service Center's Digital Coast (National Oceanic and Atmospheric Administration, 2011). 


\title{
Chapter 3. Data Integration and Visualization for the Offshore of Coal Oil Point Map Area (Sheet 4)
}

\author{
By Peter Dartnell
}

Mapping California's State Waters has produced a vast amount of acoustic and visual data, including bathymetry, acoustic backscatter, seismic-reflection profiles, and seafloor video and photography. These data are used by researchers to develop maps, reports, and other tools to assist in the coastal and marine spatial-planning capability of coastal-zone managers and other stakeholders. For example, seafloor-character (sheet 5), habitat (sheet 7), and geologic (sheet 10) maps of the Offshore of Coal Oil Point map area may assist in the designation of Marine Protected Areas, as well as in their monitoring. These maps and reports also help to analyze environmental change owing to sea-level rise and coastal development, to model and predict sediment and contaminant budgets and transport, to site offshore infrastructure, and to assess tsunami and earthquake hazards. To facilitate this increased understanding and to assist in product development, it is helpful to integrate the different datasets and then view the results in three-dimensional representations such as those displayed on the data integration and visualization sheet for the Offshore of Coal Oil Point map area (sheet 4).

The maps and three-dimensional views on sheet 4 were created using a series of geographic information systems (GIS) and visualization techniques. Using GIS, the bathymetric and topographic data (sheet 1) were converted to ASCIIRASTER format files, and the acoustic-backscatter data (sheet 3) were converted to geoTIFF images. The bathymetric and topographic data were imported in the Fledermaus ${ }^{\circledR}$ software (QPS). The bathymetry was color-coded to closely match the colored shadedrelief bathymetry on sheet 1 in which reds and oranges represent shallower depths and dark blues and purples represent deeper depths. Topographic data were shown in gray shades. The acoustic-backscatter geoTIFF images were also draped over the bathymetry data. The colored bathymetry, topography, and draped backscatter were then tilted and panned to create the perspective views such as those shown in figures 1, 2, 3, 5, and 6 on sheet 4. These views show a few examples of the complex shelf morphology in the Offshore of Coal Oil Point map area, as well as the head of the submarine Goleta landslide complex.

Video-mosaic images created from digital seafloor video (for example, fig. 4 on sheet 4) display the geologic complexity (rock, sand, and mud; see sheet 10) and biologic complexity (see sheet 12) of the seafloor. Whereas photographs capture high-quality snapshots of smaller areas of the seafloor (see sheet 6), video mosaics capture larger areas and can show transition zones between seafloor environments. Digital seafloor video is collected from a camera sled towed approximately 1 to 2 meters over the seafloor, at speeds of less than 1 nautical mile/hour. Using standard video-editing software, as well as software developed at the Center for Coastal and Ocean Mapping, University of New Hampshire, the digital video is converted to AVI format, cut into 2-minute sections, and desampled to every second or third frame. The frames are merged together using pattern-recognition algorithms from one frame to the next and converted to a TIFF image. The images are then rectified to the bathymetry data using ship navigation recorded with the video and layback estimates of the towed camera sled.

Block diagrams that combine the bathymetry or draped acoustic-backscatter imagery with seismic-reflection-profile data help integrate surface and subsurface observations, especially stratigraphic and structural relations (for example, fig. 1 on sheet 4). These block diagrams were created by converting digital seismic-reflection-profile data (Sliter and others, 2008) into TIFF images, while taking note of the starting and ending coordinates and maximum and minimum depths. The images were then imported into the Fledermaus ${ }^{\circledR}$ software as vertical images and merged with the bathymetry or acoustic-backscatter imagery. 


\title{
Chapter 4. Seafloor-Character Map of the Offshore of Coal Oil Point Map Area (Sheet 5)
}

\author{
By Eleyne L. Phillips, Mercedes D. Erdey, and Guy R. Cochrane
}

The California State Marine Life Protection Act (MLPA) calls for protecting representative types of habitat in different depth zones and environmental conditions. A science team, assembled under the auspices of the California Department of Fish and Game (CDFG), has identified seven substrate-defined seafloor habitats in California's State Waters that can be classified using sonar data and seafloor video and photography. These habitats include rocky banks, intertidal zones, sandy or soft ocean bottoms, underwater pinnacles, kelp forests, submarine canyons, and seagrass beds. The following five depth zones, which determine changes in species composition, have been identified: Depth Zone 1, intertidal; Depth Zone 2, intertidal to 30 m; Depth Zone 3, 30 to 100 m; Depth Zone 4, 100 to 200 m; and Depth Zone 5, deeper than 200 m (California Department of Fish and Game, 2008). The CDFG habitats, with the exception of depth zones, can be considered a subset of a broader classification scheme of Greene and others (1999) that has been used by the U.S. Geological Survey (USGS) (Cochrane and others, 2003, 2005). These seafloor-character maps are generalized polygon shape files that have attributes derived from Greene and others (2007).

A 2007 Coastal Map Development Workshop, hosted by the USGS in Menlo Park, California, identified the need for more detailed (relative to Greene and others' [1999] attributes) raster products that preserve some of the transitional character of the seafloor when substrates are mixed and (or) they change gradationally. The seafloor-character map, which delineates a subset of the CDFG habitats, is a GIS-derived raster product that can be produced in a consistent manner from data of variable quality covering large geographic regions.

The following five substrate classes are identified in the Offshore of Coal Oil Point map area:

- Class I: Fine- to medium-grained smooth sediment

- Class II: Mixed smooth sediment and rock

- Class III: Rock and boulder, rugose

- Class IV: Anthropogenic material (rugged)

- Class V: Anthropogenic material (smooth, hard)

The seafloor-character map of the Offshore of Coal Oil Point map area (sheet 5) was produced using video-supervised maximum-likelihood classification of the bathymetry and intensity of return from sonar systems, following the method described by Cochrane (2008). The two variants used in this classification were backscatter intensity and derivative rugosity, which is a standard calculation performed with the National Oceanic and Atmospheric Administration (NOAA) benthic-terrain modeler (available at http://www.csc.noaa.gov/digitalcoast/tools/btm/index.html; last accessed March 4, 2013), using a 3-pixel by 3-pixel array of bathymetry. Bathymetry data were collected at two different resolutions: (1) at 2-m-resolution grid-cell size, to about 80-m water depth (data collected in 2007 by California State University, Monterey Bay, Seafloor Mapping Lab, and in 2006, 2007, and 2008 by the USGS), and (2) at 5-m-resolution in the deeper areas (data collected in 2008 by Fugro Pelagos) because of lower sounding density. In order to retain the maximum resolution for data processing purposes, the 2-m-resolution and the 5-m-resolution data were analyzed for seafloor character separately, then they were displayed together in a GIS to create the seafloor-character map on sheet 5.

Classes I, II, and III values were delineated using multivariate analysis. Classes IV and V (rugged and smooth anthropogenic material, respectively; both related to oil platforms and pipes) values 
were determined on the basis of their visual characteristics and the known location of man-made features. The separate analyses (gridded at $2 \mathrm{~m}$ and $5 \mathrm{~m}$ ) were cleaned by hand to remove data-collection artifacts (for example, the trackline nadir).

On the seafloor-character map (sheet 5), the five substrate classes have been colored to indicate the California MLPA depth zones and the Coastal and Marine Ecological Classification Standard (CMECS) slope zones (Madden and others, 2008) in which they belong. The California MLPA depth zones are Depth Zone 1 (intertidal), Depth Zone 2 (intertidal to $30 \mathrm{~m}$ ), Depth Zone 3 (30 to $100 \mathrm{~m}$ ), Depth Zone 4 (100 to $200 \mathrm{~m}$ ), and Depth Zone 5 (greater than $200 \mathrm{~m}$ ); in the Offshore of Coal Oil Point map area, only Depth Zones 2, 3, and 4 are present. The slope classes that represent the CMECS slope zones are Slope Class $1=$ flat $\left(0^{\circ}\right.$ to $\left.5^{\circ}\right)$, Slope Class $2=$ sloping $\left(5^{\circ}\right.$ to $\left.30^{\circ}\right)$, Slope Class $3=$ steeply sloping $\left(30^{\circ}\right.$ to $\left.60^{\circ}\right)$, Slope Class $4=$ vertical $\left(60^{\circ}\right.$ to $\left.90^{\circ}\right)$, and Slope Class $5=$ overhang (greater than $90^{\circ}$ ); in the Offshore of Coal Oil Point map area, only Slope Classes 1, 2, and 3 are present. The final classified seafloor-character raster map image is draped over the shaded-relief bathymetry for the area (sheets 1 and 2) to produce the image shown on the seafloor-character map on sheet 5.

The seafloor-character classification is also summarized on sheet 5 in table 1 . Fine- to mediumgrained smooth sediment (sand and mud) makes up 94.3 percent $\left(102.6 \mathrm{~km}^{2}\right)$ of the map area: 15.3 percent $\left(16.7 \mathrm{~km}^{2}\right)$ is in Depth Zone 2, 71.7 percent $\left(78.0 \mathrm{~km}^{2}\right)$ is in Depth Zone 3, and 7.3 percent (8.0 $\mathrm{km}^{2}$ ) is in Depth Zone 4. Mixed smooth sediment (sand and gravel) and rock (that is, sediment typically forming a veneer over bedrock, or rock outcrops having little to no relief) make up 5.3 percent (5.8 $\left.\mathrm{km}^{2}\right)$ of the area mapped: 1.0 percent $\left(1.1 \mathrm{~km}^{2}\right)$ is in Depth Zone 2, 1.8 percent $\left(1.9 \mathrm{~km}^{2}\right)$ is in Depth Zone 3, and 2.5 percent $\left(2.8 \mathrm{~km}^{2}\right)$ is in Depth Zone 4 . Rock and boulder, rugose (rock outcrops and boulder fields having high surficial complexity) makes up 0.3 percent $\left(0.4 \mathrm{~km}^{2}\right)$ of the map area: 0.1 percent $(0.1$ $\left.\mathrm{km}^{2}\right)$ is in Depth Zone 2, 0.1 percent $\left(0.1 \mathrm{~km}^{2}\right)$ is in Depth Zone 3, and 0.1 percent $\left(0.2 \mathrm{~km}^{2}\right)$ is in Depth Zone 4. Rugged anthropogenic material includes a pipe in Depth Zone 2 and hard material associated with oil-platform structural foundation in Depth Zone 3; together they make up less than 0.1 percent $\left(<0.1 \mathrm{~km}^{2}\right)$ of the map area. Smooth, hard anthropogenic material (scours; also, coarse sediment surrounding oil platforms), present only in Depth Zone 3, makes up less than 0.1 percent $\left(<0.1 \mathrm{~km}^{2}\right)$ of the map area.

A small number of video observations were used to supervise the numerical classification of the seafloor. All video observations (see sheet 6) are used for accuracy assessment of the seafloor-character map after classification. To compare observations to classified pixels, each observation point is assigned a class (I, II, or III), according to the visually derived, major or minor geologic component (for example, sand or rock) and the abiotic complexity (vertical variability) of the substrate recorded during groundtruth surveys (table 4-1; see also, chapter 5 of this pamphlet). Class IV and V values were determined from the visual characteristics and known locations of man-made features. Next, circular buffer areas were created around individual observation points using a 10-m radius to account for layback and positional inaccuracies inherent to the towed-camera system. The radius length is an average of the distances between the positions of sharp interfaces seen on both the video (the position of the ship at the time of observation) and sonar data, plus the distance covered during a 10-second observation period at an average speed of 1 nautical mile/hour. Each buffer, which covers more than $300 \mathrm{~m}^{2}$, contains approximately 77 pixels. The classified (I, II, III) buffer is used as a mask to extract pixels from the seafloor-character map. These pixels are then compared to the class of the buffer. For example, if the shipboard-video observation is Class II (mixed smooth sediment and rock), but 12 of the 77 pixels within the buffer area are characterized as Class I (fine- to medium-grained smooth sediment), and 15 (of the 77) are characterized as Class III (rock and boulder, rugose), then the comparison would be “Class I, 12; Class II, 50; Class III, 15” (fig. 4-1). If the video observation of substrate is Class II, then the classification is accurate because the majority of seafloor pixels in the buffer are Class II. The accuracy values in table 4-2 represent the final of several classification iterations aimed at achieving the 
best accuracy, given the variable quality of sonar data (see discussion in Cochrane, 2008) and the limited ground-truth information available when compared to the continuous coverage provided by swath sonar. Presence/absence values in table 4-2 reflect the percentages of observations where the sediment classification of at least one pixel within the buffer zone agreed with the observed sediment type at a certain location.

The seafloor in the Offshore of Coal Oil Point map area is mainly flat with small, local sedimentary-bedrock exposures (Class III) on the continental shelf. The seabed is predominantly covered by Class I sediment composed of soft, unconsolidated sand and mud. Class II sediment varies from cobbles and pebbles to flat carbonate substrate on the shelf and boulder fields to broken rock mixed with sand and gravel along the shelf break. Differentially eroded sedimentary-bedrock outcrops (Class III) are present mainly in the nearshore northwest of Coal Oil Point, in various smaller exposures along the coast, and as numerous exposed ridges along the shelf break. Exposed rock is covered intermittently by varying thicknesses of fine- (Class I) to coarse-grained (Class II) sediment (coarse sand and gravel). Several anthropogenic features associated with oil production are present, including platforms and pipelines, jetties and groins, and shell mounds beneath platforms.

The classification accuracy of Class I (2-m-resolution grid, 94 percent accurate; 5-m-resolution grid, 84 percent accurate; table 4-2) is determined by comparing the shipboard video observations and the classified map. The moderate agreement in Class II (2-m-resolution grid, 33 percent accurate; 5-m-resolution grid, 79 percent accurate) and the weak agreement in Class III (2-m-resolution grid, 17 percent accurate; 5-m-resolution grid, not applicable [zero observations]) likely are due to the distribution of small, localized rock outcrops and also to the relatively narrow, intermittent nature of transition zones from sediment to rock, as well as the size of the buffer. The bedrock outcrops in this area are composed of sedimentary rocks exhibiting differential erosion (Cochrane and Lafferty, 2002). Erosion of softer layers produces Class I and II sediments, resulting in patchy rugose rock and boulder habitat on the seafloor. A single buffered observation locale of 78 pixels, therefore, is likely to be interspersed with other classes of pixels, as well as with Class III. Percentages for presence/absence within a buffer also were calculated as a better measure of the accuracy of the classification for patchy rock habitat. Within the coverage of the 2-m-resolution grid, the presence/absence accuracy was found to be significant for Classes I, II, and III (99 percent for Class I, 81 percent for Class II, and 67 percent for Class III). Within the coverage of the 5-m-resolution seafloor-character map, the presence/absence accuracy was found to be significant for Classes I and II (96 percent for Class I, and 100 percent for Class II). However, no video observations were retrieved over Class III substrate (rock and boulder, rugose) in the 5-m-resolution seafloor-character map, nor were any video observations retrieved over Classes IV and V substrate (rugged [IV] and smooth, hard [V] anthropogenic features) in the seafloorcharacter maps of either resolution; therefore, no accuracy assessments were performed for these classes. 


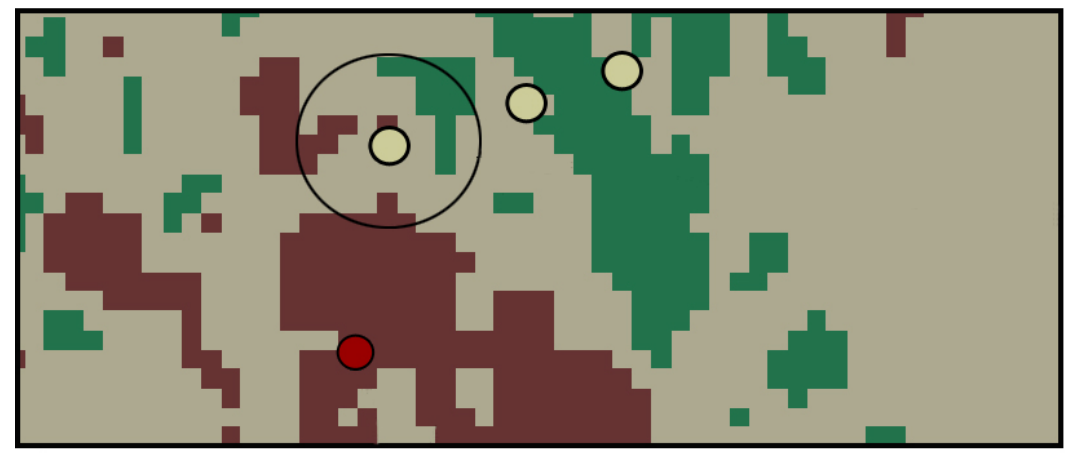

A

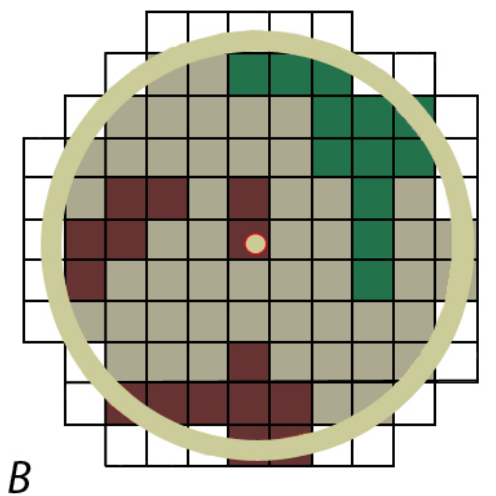

$B$

Figure 4-1. Detailed view of ground-truth data, showing accuracy-assessment methodology. $A$, Dots illustrate ground-truth observation points, each of which represents 10-second window of substrate observation plotted over seafloor-character grid; circle around dot illustrates area of buffer depicted in $B$. $B$, Pixels of seafloorcharacter data within 10-m-radius buffer centered on one individual ground-truth video observation. 
Table 4-1. Conversion table showing how video observations of primary substrate (more than 50 percent seafloor coverage), secondary substrate (more than 20 percent seafloor coverage), and abiotic seafloor complexity (in first three columns) are grouped into seafloor-character-map Classes I, II, and III for use in supervised classification and accuracy assessment in Offshore of Coal Oil Point map area.

[In areas of low visibility where primary and secondary substrate could not be identified with confidence, recorded observations of substrate (in fourth column) were used to assess accuracy]

\begin{tabular}{|c|c|c|c|}
\hline Primary-substrate component & Secondary-substrate component & Abiotic seafloor complexity & Low-visibility observations \\
\hline \multicolumn{4}{|c|}{ Class I } \\
\hline mud & mud & low & \\
\hline mud & sand & low & \\
\hline mud & sand & & \\
\hline sand & mud & & \\
\hline sand & mud & low & \\
\hline sand & sand & low & \\
\hline & & & sediment \\
\hline & & & ripples \\
\hline \multicolumn{4}{|c|}{ Class II } \\
\hline boulders & sand & & \\
\hline cobbles & sand & & \\
\hline cobbles & sand & low & \\
\hline gravel & sand & moderate & \\
\hline gravel & gravel & moderate & \\
\hline mud & cobbles & low & \\
\hline mud & gravel & low & \\
\hline mud & rock & low & \\
\hline mud & rock & moderate & \\
\hline rock & boulders & & \\
\hline rock & cobbles & & \\
\hline rock & gravel & low & \\
\hline rock & mud & low & \\
\hline rock & rock & low & \\
\hline sand & boulders & & \\
\hline sand & boulders & low & \\
\hline sand & cobbles & & \\
\hline sand & cobbles & low & \\
\hline sand & gravel & low & \\
\hline sand & gravel & moderate & \\
\hline sand & rock & & \\
\hline sand & rock & low & \\
\hline sand & rock & moderate & \\
\hline \multicolumn{4}{|c|}{ Class III } \\
\hline boulders & rock & high & \\
\hline rock & mud & high & \\
\hline rock & mud & moderate & \\
\hline rock & rock & high & \\
\hline rock & rock & moderate & \\
\hline rock & sand & high & \\
\hline rock & sand & moderate & \\
\hline
\end{tabular}


Table 4-2. Accuracy-assessment statistics for seafloor-character-map classifications in Offshore of Coal Oil Point map area.

[Accuracy assessments are based on video observations (N/A, no accuracy assessment was conducted)]

\begin{tabular}{|c|c|c|c|}
\hline Class & Number of observations & $\%$ majority & $\%$ presencelabsence \\
\hline \multicolumn{4}{|c|}{ 2-m-resolution grid } \\
\hline I-Fine- to medium-grained smooth sediment & 389 & 93.7 & 98.7 \\
\hline II-Mixed smooth sediment and rock & 68 & 33.1 & 80.9 \\
\hline III-Rock and boulder, rugose & 30 & 17.3 & 66.7 \\
\hline IV-Rugged anthropogenic feature & 0 & N/A & N/A \\
\hline V-Smooth, hard anthropogenic feature & 0 & N/A & N/A \\
\hline \multicolumn{4}{|c|}{ 5-m-resolution grid } \\
\hline I-Fine- to medium-grained smooth sediment & 24 & 83.9 & 95.8 \\
\hline II-Mixed smooth sediment and rock & 24 & 78.5 & 100.0 \\
\hline III-Rock and boulder, rugose & 0 & N/A & N/A \\
\hline IV-Rugged anthropogenic feature & 0 & N/A & N/A \\
\hline V-Smooth, hard anthropogenic feature & 0 & N/A & N/A \\
\hline
\end{tabular}




\title{
Chapter 5. Ground-Truth Studies for the Offshore of Coal Oil Point Map Area (Sheet 6)
}

\author{
By Nadine E. Golden and Guy R. Cochrane
}

To validate the interpretations of sonar data in order to turn it into geologically and biologically useful information, the U.S. Geological Survey (USGS) towed a camera sled (fig. 5-1) over specific locations throughout the Offshore of Coal Oil Point map area to collect video and photographic data that would "ground truth" the seafloor. This ground-truth surveying occurred on four separate cruises in 2006, 2007, 2008, and 2009. The camera sled was towed 1 to $2 \mathrm{~m}$ over the seafloor at speeds of between 1 and 2 nautical miles/hour. Ground-truth surveys in this map area include approximately 14.87 trackline kilometers of video and 333 still photographs, in addition to 615 recorded seafloor observations of abiotic and biotic attributes. A visual estimate of slope also was recorded.

During the 2006 and 2007 cruises, a smaller USGS camera sled was used that housed two standard-definition (640×480 pixel resolution) video cameras: one was forward looking, and the other was downward looking. During the 2008 and 2009 cruises, a larger camera sled was used that housed the two standard-definition video cameras (one forward looking and one downward looking), as well as a high-definition (1,080×1,920 pixel resolution) video camera and an 8-megapixel digital still camera. During these latter two cruises, in addition to recording the seafloor characteristics, a digital still photograph was captured once every 30 seconds.

The camera-sled tracklines (shown by colored dots on the map on sheet 6) are sited in order to visually inspect areas representative of the full range of bottom hardness and rugosity in the map area. The video is fed in real time to the research vessel, where USGS and National Oceanic and Atmospheric Administration (NOAA) scientists record both the geologic and biologic character of the seafloor. While the camera is deployed, several different observations are recorded for a 10-second period once every

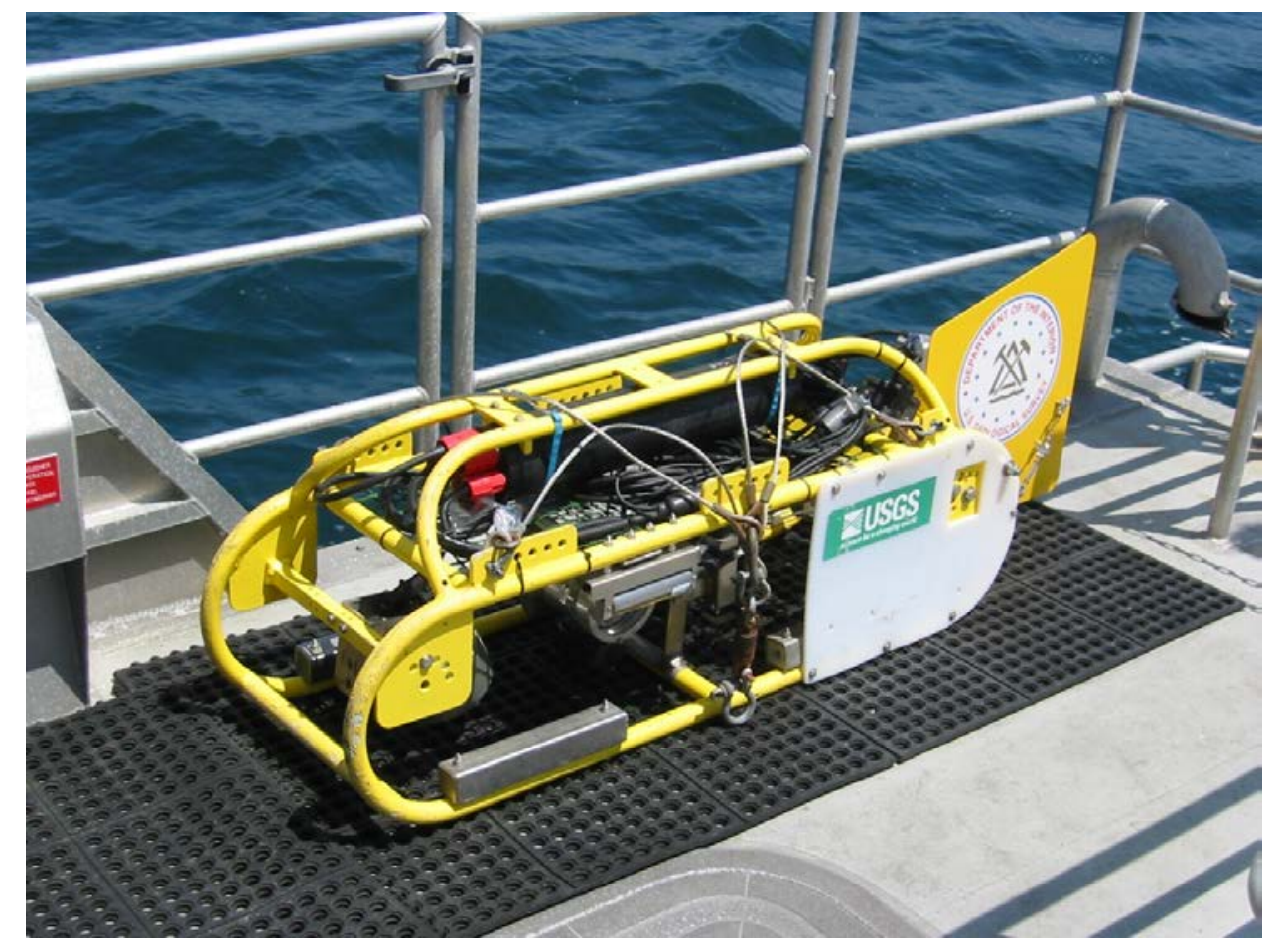

Figure 5-1. Photograph of camera sled used in USGS 2007 ground-truth survey. 
minute, using the protocol of Anderson and others (2007). Observations of primary substrate, secondary substrate, slope, abiotic complexity, biotic complexity, and biotic cover are mandatory. Observations of key geologic features and the presence of key species also are made.

Primary and secondary substrate, by definition, constitute greater than 50 and 20 percent of the seafloor, respectively, during an observation. The grain-size values that differentiate the substrate classes are based on the Wentworth (1922) scale, and the sand, cobble, and boulder sizes are classified as in Wentworth (1922). However, the difficulty in distinguishing the finest divisions in the Wentworth (1922) scale during video observations made it necessary to aggregate some grain-size classes, as was done in the Anderson and others (2007) methodology: the granule and pebble sizes have been grouped together into a class called "gravel," and the clay and silt sizes have been grouped together into a class called "mud.” In addition, hard bottom and clasts larger than boulder size are classified as "rock." Benthic-habitat complexity, which is divided into abiotic (geologic) and biotic (biologic) components, refers to the visual classification of local geologic features and biota that potentially can provide refuge for both juvenile and adult forms of various species (Tissot and others, 2006).

Sheet 6 contains a smaller, simplified (depth-zone symbology has been removed) version of the seafloor-character map on sheet 5. On this simplified map, the camera-sled tracklines used to groundtruth-survey the sonar data are shown by aligned colored dots, each dot representing the location of a recorded observation. A combination of the abiotic attributes (primary- and secondary-substrate compositions), as well as vertical variability, were used to create the different classes represented on the seafloor-character map (sheet 5): on the simplified map, the derived classes are represented by colored dots. Also on this map are locations of the detailed views of seafloor character, shown by boxes (Boxes A through E); for each view, the box shows the locations (indicated by colored stars) of representative seafloor photographs. For each photograph, an explanation of the observed seafloor characteristics recorded by USGS and NOAA scientists is given. Note that individual photographs often show more substrate types than are reported as the primary and secondary substrate. Organisms, when present, are labeled on the photographs.

The ground-truth survey is designed to investigate areas that represent the full spectrum of highresolution multibeam bathymetry and backscatter-intensity variation. Figure 5-2 shows that, in the Offshore of Coal Oil Point map area, the seafloor surface is covered by sediment; the three predominant substrates are mixed sediment and rock and a few areas of exposed rock outcrop. In addition, two anthropogenic features related to oil and gas production are visible in the midshelf area, and large headwall scarps of landslides are present at the edge of the shelf. 


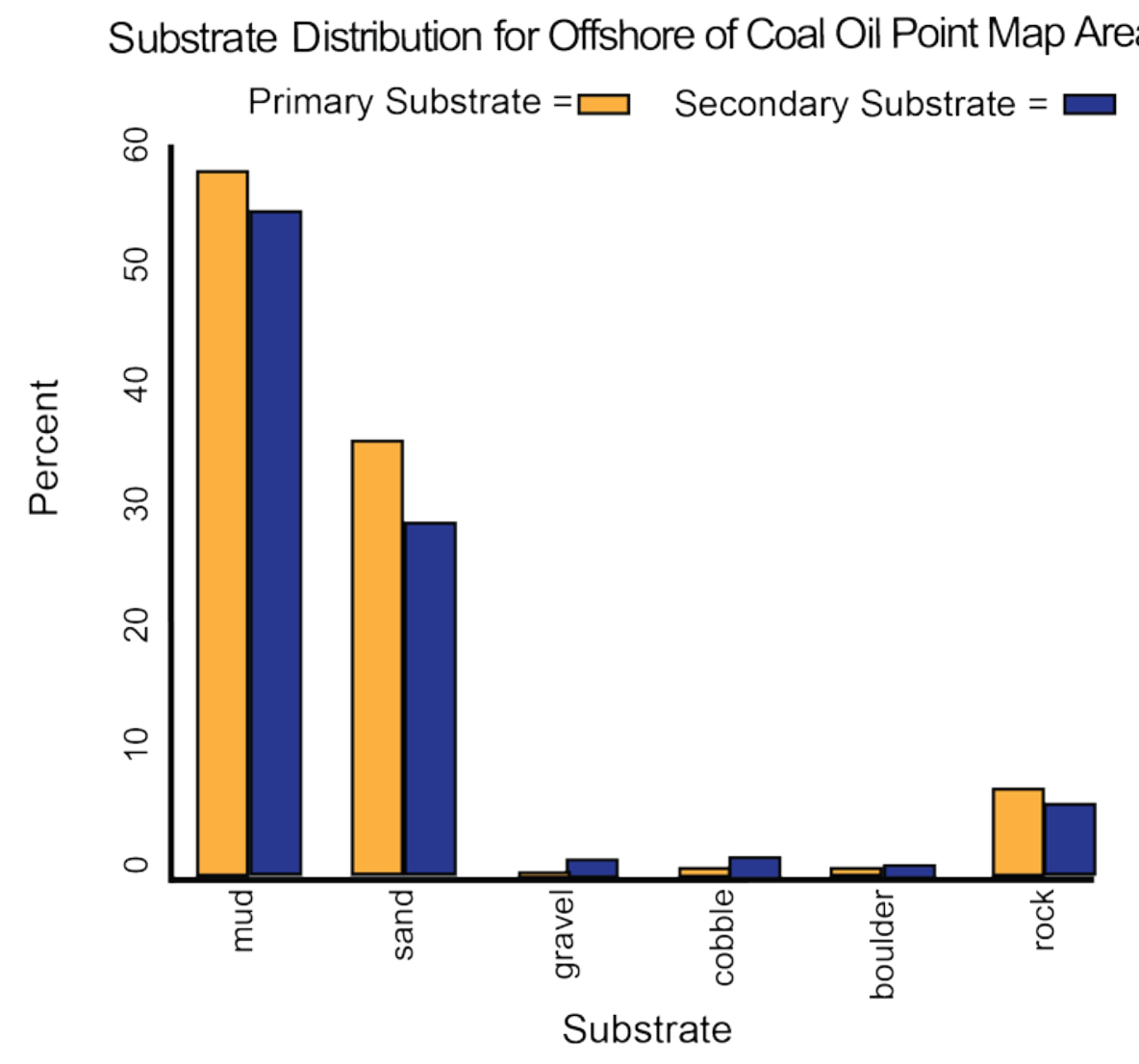

Figure 5-2. Graph showing distribution of primary and secondary substrate determined from video observations in Offshore of Coal Oil Point map area. 


\title{
Chapter 6. Potential Marine Benthic Habitat Map of the Offshore of Coal Oil Point Map Area (Sheet 7)
}

\author{
By H. Gary Greene and Charles A. Endris
}

The map on sheet 7 shows "potential" marine benthic habitats in the Offshore of Coal Oil Point map area, representing a substrate type, geomorphology, seafloor process, or any other attribute that may provide a habitat for a specific species or assemblage of organisms. This map, which is based largely on seafloor geology, also integrates information displayed on several other thematic maps of the Offshore of Coal Oil Point map area. High-resolution sonar bathymetry data, converted to depth grids (seafloor DEMs; sheet 1), are essential to development of the potential marine benthic habitat map, as is shadedrelief imagery (sheet 2), which allows visualization of seafloor terrain and provides a foundation for interpretation of submarine landforms.

Backscatter maps (sheet 3) are also essential for developing potential benthic habitat maps. High backscatter is further indication of "hard" bottom, consistent with interpretation as rock or coarse sediment. Low backscatter, indicative of a "soft" bottom, generally indicates a fine sediment environment. Habitat interpretations are also informed by actual seafloor observations from ground-truth surveying (sheet 6), by seafloor-character maps that are based on video-supervised maximum-likelihood classification (sheet 5), and by seafloor-geology maps (sheet 10). The habitat interpretations on sheet 7 are further informed by the usSEABED bottom-sampling compilation of Reid and others (2006).

Broad, generally smooth areas of seafloor that lack sharp and angular edge characteristics are mapped as "sediment;" these areas may be further defined by various sedimentary features (for example, erosional scours and depressions) and (or) depositional features (for example, dunes, mounds, or sand waves). In contrast, many areas of seafloor bedrock exposures are identified by their common sharp edges and high relative relief; these may be contiguous outcrops, isolated parts of outcrop protruding through sediment cover (pinnacles or knobs), or isolated boulders. In many locations, areas within or around a rocky feature appear to be covered by a thin veneer of sediment; these areas are identified on the habitat map as "mixed" induration (that is, containing both rock and sediment). The combination of remotely observed data (for example, high-resolution bathymetry and backscatter, seismic-reflection profiles) and directly observed data (for example, camera transects, sediment samples) translates to higher confidence in the ability to interpret broad areas of the seafloor.

To avoid any possible misunderstanding of the term "habitat," the term "potential habitat" (as defined by Greene and others, 2005) is used herein to describe a set of distinct seafloor conditions that in the future may qualify as an "actual habitat." Once habitat associations of a species are determined, they can be used to create maps that depict actual habitats, which then need to be confirmed by in situ observations, video, and (or) photographic documentation.

\section{Classifying Potential Marine Benthic Habitats}

Potential marine benthic habitats in the Offshore of Coal Oil Point map area are mapped using the Benthic Marine Potential Habitat Classification Scheme, a mapping-attribute code developed by Greene and others (1999, 2007). This code, which has been used previously in other offshore California areas (see, for example, Greene and others, 2005, 2007), was developed to easily create categories of marine benthic habitats that can then be queried within a GIS or a database. The code contains several categories that can be subdivided relative to the spatial scale of the data. The following categories can be applied directly to habitat interpretations determined from remote-sensing imagery collected at a scale of tens of kilometers to one meter: Megahabitat, Seafloor Induration, Meso/Macrohabitat, Modifier, Seafloor Slope, Seafloor Complexity, and Geologic Unit. Additional categories of Macro/Microhabitat, 
Seafloor Slope, Seafloor Complexity, and Geologic Attribute can be applied to habitat interpretations determined from seafloor samples, video, still photographs, or direct observations at a scale of 10 meters to a few centimeters. These two scale-dependent groups of categories can be used together, to define a habitat across spatial scales, or separately, to compare large- and small-scale habitat types.

The six categories and their attribute codes that are used on Offshore of Coal Oil Point map are explained in detail below (note, however, that not all categories may be used in a particular map area, given the study objectives, data availability, or data quality); attribute codes in each category are depicted on the map by the letters and, in some cases, numbers that make up the map-unit symbols:

Megahabitat-Based on depth and general physiographic boundaries; used to distinguish features on a scale of tens of kilometers to kilometers. Depicted on map by capital letter, listed first in map-unit symbol; generalized depth ranges are given below.

$\mathrm{F}=\quad$ Flank; continental slope, basin and (or) island flanks (200 to 3,000 m)

$\mathrm{S}=\quad$ Shelf; continental and island shelves (0 to $200 \mathrm{~m})$

Seafloor Induration-Refers to substrate hardness. Depicted on map by lower-case letter, listed second in map-unit symbol; may be further subdivided into distinct sediment types, depicted by lowercase letter(s) in parentheses, listed immediately after substrate hardness; multiple attributes listed in general order of relative abundance, separated by slash; queried where inferred.

$\begin{array}{ll}\mathrm{h}= & \text { Hard bottom (for example, rock outcrop or sediment pavement) } \\ \mathrm{m}= & \text { Mixed hard and soft bottom (for example, local sediment cover of bedrock) } \\ \mathrm{s}= & \text { Soft bottom; sediment cover } \\ (\mathrm{c})= & \text { Cobbles } \\ (\mathrm{g})= & \text { Gravel } \\ (\mathrm{s})= & \text { Sand } \\ (\mathrm{m})= & \text { Mud, silt, and (or) clay } \\ (\mathrm{p})= & \text { Pebbles }\end{array}$

Meso/Macrohabitat — Related to scale of habitat; consists of seafloor features one kilometer to one meter in size. Depicted on map by lower-case letter and, in some cases, additional lower-case letter in parentheses, listed third in map-unit symbol; multiple attributes separated by slash.
$\mathrm{b}=\quad$ Beach, relic (submerged) or shoreline
$(b) / p=$ Pinnacle indistinguishable from boulder
$\mathrm{C}=$
$\mathrm{c}(\mathrm{b})=\quad$ Bar within thalweg
$c(c)=\quad$ Curve or meander within thalweg
$c(f)=\quad$ Fall or chute within thalweg
$\mathrm{c}(\mathrm{h})=\quad$ Canyon head
$\mathrm{c}(\mathrm{m})=\quad$ Canyon mouth
$\mathrm{c}(\mathrm{t})=\quad$ Thalweg
$\mathrm{c}(\mathrm{w})=\quad$ Canyon wall
$d=\quad$ Deformed, tilted and (or) folded bedrock; overhang
$\mathrm{e}=\quad$ Exposure; bedrock
$f=\quad$ Flat; floor
$\mathrm{g}=\quad$ Gully; channel
$\mathrm{h}=\quad$ Hole; depression
$\mathrm{I}=\quad$ Landslide; mass movement; rubble
$\mathrm{m}=\quad$ Mound; linear ridge
$\mathrm{o}=\quad$ Overbank deposit; levee
$\mathrm{p}=\quad$ Pinnacle; cone
$r=\quad$ Rill (linear depression on surface formed by subterranean winnowing of sediment) 


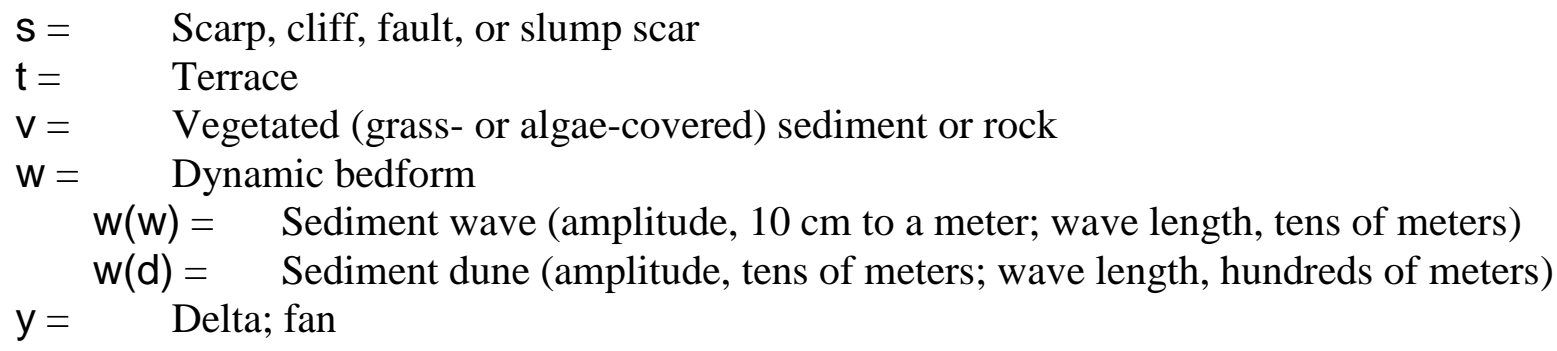

Modifier-Describes texture, bedforms, biology, or lithology of seafloor. Depicted on map by lower-case letter, in some cases followed by additional lower-case letter(s) either after a hyphen or in parentheses (or both), following an underscore; multiple attributes separated by slash.

- $\mathrm{a}=\quad$ Anthropogenic (artificial reef, breakwall, shipwreck, disturbance)

a-c $=$ Cable

_a-dd $=$ Dredge disturbance

- $\mathrm{a}-\mathrm{dg}=$ Dredge groove or channel

a-dp $=$ Dredge potholes

-a-dm = Dredge mound (disposal)

-a-dp $=$ Dredge pothole

_a-f = Ferry (or other vessel) propeller-wash scour or scar

_a-g = Groin, jetty, rip-rap

a-m = Marina, harbor

_a-p = Pipeline

_a-s = Support; dock piling, dolphin

-a-td $=$ Trawl disturbance

-a-w = Wreck, ship, barge, or plane

- $\mathrm{b}=\quad$ Bimodal (conglomeratic, mixed [gravel, cobbles, and pebbles])

_ $\mathrm{c}=$ Consolidated sediment (claystone, mudstone, siltstone, sandstone, breccia, or conglomerate)

_ $\mathrm{d}=\quad$ Differentially eroded

_e $=\quad$ Effusive pit; pockmark

$-\mathrm{f}=\quad$ Fracture, joint; faulted

_g $=$ Granite

_ $\mathrm{h}=$ Hummocky, irregular relief

_ $\mathrm{i}=$ Interface; lithologic contact

- $\mathrm{k}=$ Kelp

_ $=\quad$ Limestone or carbonate rock or structure

$-\mathrm{I}(\mathrm{a})=\quad$ Alive reef

$\mathrm{I}(\mathrm{d})=\quad$ Dead reef

-I $(\mathrm{l})=\quad$ Linear reef

$-I(p)=\quad$ Patch reef

- $I($ pr-a $)=$ Aggregated patch reef

I $($ pr-i $)=$ Individual patch reef

$-l(r)=\quad$ Reef rubble

- $(\mathrm{s}-\mathrm{g})=$ Spur and groove

_ $\mathrm{m}=\quad$ Massive sedimentary bedrock

o $=$ Outwash

_p $=$ Pavement

_ $r=$ Ripple (amplitude, greater than $10 \mathrm{~cm}$ )

_ $=\quad$ Scour (current or ice; direction noted) 


$\begin{array}{ll}\mathrm{t}= & \text { Asphalt (tar) } \\ -\mathrm{u}= & \text { Unconsolidated sediment } \\ \mathbf{v}= & \text { Volcanic rock } \\ \mathbf{w}= & \text { Wall }\end{array}$

Seafloor Slope-Denotes slope, typically calculated from XYZ high-resolution bathymetry data. Depicted on map by number, listed after modifier.

$\begin{array}{ll}1= & \text { Flat }\left(0^{\circ}-5^{\circ}\right) \\ 2= & \text { Sloping }\left(5^{\circ}-30^{\circ}\right) \\ 3= & \text { Steeply sloping }\left(30^{\circ}-45^{\circ}\right) \\ 4= & \text { Vertical or near vertical }\left(45^{\circ}-90^{\circ}\right) \\ 5= & \left.\text { Overhanging (more than } 90^{\circ}\right) \\ 6= & \text { Unknown }\end{array}$

Geologic Attribute-Describes additional geologic features seen in video, still photographs, or other types of direct observations. Depicted on map by lower-case letter(s) in parentheses, preceded by an asterisk.

* $(\mathrm{a})=$ Anthropogenic (for example, cable, pipeline, disturbance)

* $(\mathrm{a}-\mathrm{d})=$ Dredge track, pit, or mound

$*(b)=$ Boulder

*(d) $=$ Deformed, faulted, or folded

$*(e)=$ Exposure, bedrock (sedimentary, igneous, or metamorphic)

* $(e-r)=$ Rough bedrock surface

$*(f)=$ Fan or apron

$*(g)=$ Gravel

*(j) $=$ Joint, crack, crevice, overhang (differentially eroded)

$*(I)=$ Limestone, carbonate deposit

$\star(\mathrm{m})=$ Mud, silt, or clay

$*(q)=$ Coquina (shell hash)

$*(r)=$ Rubble

$\star(s)=$ Sand

$*(\mathrm{t})=$ Flat, terracelike seafloor, including sedimentary pavement

* $(\mathrm{u})=$ Undulating surface, hummocky

$\star(u-r)=$ Ripple

$*(\mathrm{u}-\mathrm{S})=$ Scour

$*(\mathrm{u}-\mathrm{w})=$ Sediment wave

* $(y)=$ Barnacle or plate

\section{Examples of Attribute Coding}

To illustrate how these attribute codes can be used to describe remotely sensed data, the following examples are given:

Ssc(h)_u2/4 = Canyon head that indents shelf and has smooth, soft, gently sloping, sedimentary walls, locally cropping out as steep (near vertical) scarps (10 to $100 \mathrm{~m}$ ).

Ssf_u1 = Flat to gently sloping shelf that has soft, unconsolidated sediment (10 to $150 \mathrm{~m})$.

Fhe_ $\mathrm{m} / \mathrm{c}=$ Continental slope that has hard sedimentary (sandstone) bedrock exposures locally and smooth to moderately irregular relief (less than $1 \mathrm{~m}$ to $3 \mathrm{~m}$ high); exposures often covered with sediment (200 to 2,500 m).

Ssm_a/u* $(q)=$ Soft, unconsolidated sediment and shell-hash mound, adjacent to oil platform (anthropogenic). 


\section{Map Area Habitats}

Delineated in the Offshore of Coal Oil Point map area are 24 potential marine benthic habitat types within two megahabitat settings, "Shelf” (continental shelf) and "Flank" (basin flank or continental slope). On the shelf, these habitat types range from predominantly soft, unconsolidated sediment (sand and mud to cobbles and pebbles) to areas of hard bedrock exposures (flat carbonate substrate; differentially eroded, well-bedded sedimentary outcrops). Some sedimentary-bedrock outcrops are partly covered with sediment to produce a hard-soft mixed habitat type. Pockmarks, asphalt (tar) mounds, and carbonate mounds complete the variety of habitats identified on the continental shelf. Significant anthropogenic features associated with oil production, such as platforms, pipelines, and shell mounds beneath platforms, as well as remnant mounds from past seafloor development, all produce artificial habitats for rockfish (Sebastes spp.). The narrow band of basin-flank or continental-slope megahabitat that has been mapped contains macro- and mesohabitats of predominantly soft, unconsolidated sediment that has numerous pockmarks and rills, which suggests a "leaky" area where gas and fluids associated with petroleum reservoirs at depth have been seeping from the seafloor.

The soft, unconsolidated sediment habitat on the continental shelf, which includes pockmarks and inferred sediment-covered tar flows (see sheet 11 of this report), covers $78.13 \mathrm{~km}^{2}$ of the total $109.65 \mathrm{~km}^{2}$ area mapped, representing 71.3 percent of all the potential habitat types identified. Sediment-covered bedrock on the continental shelf, which includes the hard-soft mixed habitat type, covers $5.17 \mathrm{~km}^{2}$ (about 4.7 percent). Hard bedrock exposures on the continental shelf cover $14.41 \mathrm{~km}^{2}$ (about 13.2 percent), whereas anthropogenic features on the continental shelf cover nearly $0.1 \mathrm{~km}^{2}$ but represent only a small fraction of habitats mapped. Soft, unconsolidated sediment habitat on the basin flank covers $10.3 \mathrm{~km}^{2}$ (9.4 percent), and hard bedrock exposures at the top of the continental slope cover $1.5 \mathrm{~km}^{2}$ (1.4 percent).

Fluid flowing up to the seafloor from petroleum reservoirs at depth has resulted in the formation of locally exposed hard, carbonate-cemented sediment substrate, carbonate mounds, pockmarks, and asphalt (tar) mounds. Sheet 11 of this report shows detail of seafloor hydrocarbon seepage and related asphalt and tarball accumulations. Exposed carbonate mounds and associated hard ground are locally covered with sediment, providing potential habitat for sessile organisms. The mix of potential marine benthic habitat types provides varied relief, rugosity, and substrate hardness that may contribute to the concentration of a diverse marine ecosystem within an otherwise homogeneous, soft, unconsolidated sediment habitat. 


\section{Chapter 7. Subsurface Geology and Structure of the Offshore of Coal Oil Point Map Area and the Santa Barbara Channel Region (Sheets 8 and 9)}

By Samuel Y. Johnson, James E. Conrad, Eleyne L. Phillips, Andrew C. Ritchie, Florence L. Wong, Ray W. Sliter, Amy E. Draut, and Patrick E. Hart

The seismic-reflection profiles presented on sheet 8 provide a third dimension, depth, to complement the surficial seafloor-mapping data already presented (sheets 1 through 7) for the Offshore of Coal Oil Point map area. These profiles, which are collected at several resolutions, extend to varying depths in the subsurface, depending on the purpose and mode of data acquisition. The seismic-reflection profiles (sheet 8) provide information on sediment character, distribution, and thickness, as well as potential geologic hazards, including active faults, areas prone to strong ground motion, and tsunamigenic slope failures. The information on faults provides essential input to national and state earthquake-hazard maps and assessments (for example, Petersen and others, 2008; Wills and others, 2008).

The maps on sheet 9 shows the following interpretations, which are based on the seismicreflection profiles on sheet 8: the thickness of the uppermost sediment unit; the depth to base of this uppermost unit; and both the local and regional distribution of faults and earthquake epicenters (data from Heck, 1998; Minor and others, 2009; Jennings and Bryant, 2010; Southern California Earthquake Data Center, 2010).

\section{Data Acquisition}

Most profiles displayed on sheet 8 (figs. 1, 2, 3, 4, 5, 8, 9) were collected in 2007 on U.S. Geological Survey (USGS) cruise Z-3-07-SC (Sliter and others, 2008). Single-channel seismicreflection data were acquired using two different sources, the EdgeTech 512 chirp (figs. 1, 2, 4, 5) and the SIG 2Mille minisparker (figs. 3, 8, 9). The EdgeTech 512 chirp subbottom-profiling system consists of a source transducer and an array of receiving hydrophones housed in a 500-lb fish towed at a depth of several meters below the sea surface. The swept-frequency chirp source signal was 500 to 4,500 $\mathrm{Hz}$ and $50 \mathrm{~ms}$ in length, and it was recorded by hydrophones located on the bottom of the fish. The SIG minisparker system used a 500-J high-voltage electrical discharge fired 1 to 4 times per second, which, at normal survey speed of 4 to 4.5 nautical miles/hour, gives a data trace every 0.5 to $2.0 \mathrm{~m}$ of lateral distance covered. The data were digitally recorded in standard SEG-Y 32-bit floating-point format, using Triton Subbottom Logger (SBL) software that merges seismic-reflection data with differential GPS-navigation data. After the survey, a short-window $(20 \mathrm{~ms})$ automatic gain control algorithm was applied to both the chirp and minisparker data, and a 160- to 1,200-Hz bandpass filter was applied to the minisparker data. These high-resolution data can resolve geologic features that are a few meters thick (small-scale features) to subbottom depths of as much as a few hundred meters.

Figures 6 and 7 on sheet 8 show deep-penetration, migrated, multichannel seismic-reflection profiles collected by WesternGeco in 1984 (cruise W-37-84-SC; fig. 6) and 1985 (cruise W-6-85-SC; fig. 7). These profiles and other similar data were collected in many areas offshore of California in the 1970s and 1980s when these areas were considered a frontier for oil and gas exploration. Much of these data have been publicly released and are now archived at the U.S. Geological Survey National Archive of Marine Seismic Surveys (U.S. Geological Survey, 2009). These data were acquired using a largevolume air-gun source that has a frequency range of 3 to $40 \mathrm{~Hz}$ and recorded with a multichannel 
hydrophone streamer about $2 \mathrm{~km}$ long. Shot spacing was about $30 \mathrm{~m}$. These data can resolve geologic features that are 20 to $30 \mathrm{~m}$ thick, down to subbottom depths of about $4 \mathrm{~km}$.

\section{Seismic-Reflection Imaging of the Continental Shelf}

Sheet 8 shows seismic-reflection profiles in the Offshore of Coal Oil Point map area that document a relatively flat (about $1.1^{\circ}$ ), moderately deep (less than $90 \mathrm{~m}$ ) shelf. This shelf is underlain by variably thick ( 0 to about $17 \mathrm{~m}$; mean thickness, $4.0 \mathrm{~m}$ ) upper Pleistocene and Holocene marine, deltaic, and alluvial sediments (Draut and others, 2009; Sommerfield and others, 2009) deposited in the last about 21,000 years during the about 125-m sea-level rise that followed glaciation and the last major sealevel lowstand. Sea-level rise after the Last Glacial Maximum (LGM) was rapid (as much as $15 \mathrm{~m}$ per thousand years) until about 7,000 years ago, at which time it slowed considerably (to about $1 \mathrm{~m}$ per thousand years) (Fairbanks, 1989; Fleming and others, 1998; Lambeck and Chappell, 2001; Peltier and Fairbanks, 2006; Stanford and others, 2011). Local relief on the shelf is associated with bedrock uplifts (sheet 10).

The sediments deposited during this latest Pleistocene and Holocene sea-level rise are shaded blue in the high-resolution seismic-reflection profiles on sheet 8 (figs. 1, 2, 3, 4, 5, 8, 9), and their thickness is shown on sheet 9. In the minisparker profiles (figs. 3, 8, 9 on sheet 8), these strata are typically characterized by parallel, low- to moderate-amplitude, low- to high-frequency, continuous to moderately continuous reflections (terminology from Mitchum and others, 1977); an upward decrease in reflection amplitude is seen on many of these profiles. In the chirp seismic-reflection profiles (figs. 1, 2, 4, 5 on sheet 8), this stratigraphic interval has fewer internal reflections and, in places, is partly “acoustically transparent” (that is, lacking internal reflections). The presence and continuity of seismic reflections in this upper, post-LGM unit on many profiles is also obscured by interstitial gas within the sediment. This effect has been referred to as "gas blanking," "acoustic turbidity," or "acoustic masking” (Hovland and Judd, 1988; Fader, 1997). The gas scatters or attenuates the acoustic energy, preventing penetration. Not surprisingly, this effect is especially prevalent near the South Ellwood and Coal Oil Point offshore hydrocarbon fields (Brickey, 1998) and near the crests of other anticlines.

Because the shelf was partly emergent during the postglacial period of rising sea level, the lower part of the post-LGM unit may, in places (especially where the unit is thickest), consist of alluvial plain and estuarine deposits. These nonmarine to marginal-marine strata were covered by nearshore and shelf sediments as sea level rose and the shoreline migrated both landward and upward. The upper part of this unit likely consists of a mix of shelf and deltaic deposits that are similar to the sediment being deposited on the shelf today (see sheet 6).

On most profiles on sheet 8, the base of the post-LGM depositional unit is a flat to concave angular unconformity, characterized by a high-amplitude reflection. Post-LGM sediment onlapping of local uplifts (for example, figs. 1, 9) is common. Sediment-covered wave-cut platforms and risers (see, for example, Kern, 1977) are imaged at the base of the unit on some profiles, most commonly at depths of about 40 to $50 \mathrm{~m}$ (see, for example, figs. 1, 2, 5). Given uplift rates from nearby coastal terraces (Trecker and others, 1998; Keller and Gurrola, 2000, their fig. 6), these depths are most consistent with formation during the post-LGM transgression. Post-LGM sea-level rise and landward shoreline migration were not steady but, rather, were characterized by periods of relative stability and rapid submergence (see, for example, Peltier, 2005; Stanford and others, 2011). For example, sea level rose about $20 \mathrm{~m}$ in 200 to 500 years during meltwater pulse 1a, about 14,000 years ago (Stanford and others, 2011). Such pulses rapidly submerge wave-cut platforms, shorelines, and shoreline angles (Kern, 1977), thereby increasing the potential for their preservation 


\section{Seismic-Reflection Imaging of the Upper Slope and the Submarine Goleta Landslide Complex}

The Offshore of Coal Oil Point map area includes the upper part of the large $\left(130 \mathrm{~km}^{2}\right)$, welldocumented submarine Goleta landslide complex (Eichhubl and others, 2002; Fisher and others, 2005; Greene and others, 2006). Greene and others (2006) reported that the Goleta landslide complex, which measures 14.6-km long and 10.5-km wide and extends from water depths of 90 to $574 \mathrm{~m}$, has displaced about $1.75 \mathrm{~km}^{3}$ of landslide debris during the Holocene. They described a compound submarine landslide that contains both surficial slump blocks and mud flows, in three distinct segments. Each segment is composed of a distinct headscarp, a downdropped "head block" (see Greene and others, 2006), and a slide-debris lobe. The map on sheet 10 shows the geologic and geomorphologic units within the upper about $3 \mathrm{~km}$ of this landslide complex (the part within the map area), and seismicreflection profile SB-145 (fig. 3 on sheet 8) illustrates its subsurface characteristics.

The outer shelf along profile SB-145 (fig. 3 on sheet 8), which slopes about $1.0^{\circ}$ to the south, is underlain by south-dipping (about $30^{\circ}$ ) bedrock and a thin veneer of fine-grained sediment that, notably, hosts dense pockmarks that are associated with gas seeps (see sheet 10). The upper slope, which dips about $6^{\circ}$, is underlain by a perched sediment lens, as thick as $30 \mathrm{~m}$; this lens is characterized by moderate-amplitude, moderate- to high-frequency, slope-parallel reflections that have been rotated by sliding into both convex and concave geometries. Fisher and others (2005) considered these strata to be part of a Quaternary-age shelf-edge delta, presumably deposited during the last sea-level lowstand. The landslide headwall (about $250 \mathrm{~m}$ wide) is present seaward of, and dips more steeply (about $12^{\circ}$ ) than, the upper slope.

The upper part of the landslide complex (considered the "head block" by Greene and others, 2006) lies below the headwall (see south end of profile SB-145; fig. 3 on sheet 8), its slope decreasing from about $6^{\circ}$ to $2^{\circ}$ over about $2 \mathrm{~km}$. The slide-debris material in the head block is characterized by moderate-amplitude, high-frequency, continuous, parallel reflections that have been locally warped into mounds by rotation and compression during landsliding. The geometry of the unconformity at the base of the landslide complex (above south-dipping bedrock) ranges from subparallel, higher up on the slope, to angular, at the base of the slope.

Fisher and others (2005) and Greene and others (2006) listed several factors that may have contributed to the development of the submarine Goleta landslide complex: (1) strong ground motions generated by local earthquakes; (2) steeply south-dipping slopes in the bedrock along the shelf edge, facilitating slope failure along bedding planes; (3) steep slopes created by folding above a regional thrust fault (see section below), combined with high sediment supply to the shelf edge during sea-level lowstand; and (4) rock and sediment layers weakened by active hydrocarbon seepage.

\section{Geologic Structure and Recent Deformation}

Geologic structure in the Offshore of Coal Oil Point map area is complex (see, for example, Leifer and others, 2010). The dominant structure is the east-west-striking North Channel Fault, a northdipping blind thrust fault that underlies the outer shelf and upper slope. The continuous fault system can be mapped with deeper, industry seismic-reflection data (for example, figs. 6, 7 on sheet 8), but the fault tip apparently is offset laterally about $1.5 \mathrm{~km}$ southward, from east to west, by a presumed cross fault south of Coal Oil Point.

The South Ellwood Anticline (see sheet 10), a hanging-wall anticline above the North Channel Fault, hosts platform "Holly" and the South Ellwood offshore oil and gas field (see sheet 11; Hornafius and others, 1999; Leifer and others, 2010). This anticline can be traced eastward in the offshore (as the Rincon Anticline) for more than $40 \mathrm{~km}$ to its landfall near Punta Gorda, about $30 \mathrm{~km}$ east of the map area, between Ventura and Carpinteria (see fig. 1-1). In the western part of the map area, the anticline 
transitions to a flexure within the south-dipping limb of the large, regional homocline that extends from the south flank of the Santa Ynez Mountains into the offshore.

In the eastern part of the map area, the axis of the South Ellwood Syncline lies less than $1 \mathrm{~km}$ north of the South Ellwood Anticline (sheet 10); this syncline axis also can be traced eastward for more than $40 \mathrm{~km}$. East of Coal Oil Point, the South Ellwood Syncline overlies and (or) coincides with the steeply south-dipping, north strand of the Red Mountain Fault. West of Coal Oil Point, this syncline similarly transitions to a flexure in the regional, south-dipping homocline.

North of the South Ellwood folds, in the eastern part of the map area, the pattern of shallow folding (see sheet 10) suggests that the upper plate of the North Channel Fault includes numerous blind splay faults (north-dipping thrusts and south-dipping back thrusts). The east-west-striking Coal Oil Point Anticline, located about $1.5 \mathrm{~km}$ north of the South Ellwood Anticline (sheet 10), is the most prominent of these folds. This anticline can be traced in the offshore for about $9 \mathrm{~km}$ before it dies out to both the east and west. Several other associated folds that have variable dips, wavelengths, and amplitudes have shorter surface traces (a few kilometers long). Such folding is uncommon west of Coal Oil Point, an along-strike structural transition that is consistent with two markedly different but well-constrained, north-south-striking geologic cross sections that extend across the Naples gas field (see sheet 11; Brickey, 1998), in the western part of the map area (Redin, 2005), and the South Ellwood field, in the eastern part of the map area (Redin and others, 2005; Leifer and others, 2010). An east-to-west transition in structural style in this area also is consistent with large, lateral variations in coastal-uplift rates recorded by emergent marine terraces (Trecker and others, 1998; Gurrola and others, 2014).

The Isla Vista Fault (see fig. 5 on sheet 8), mapped onshore by Minor and others (2009), extends into the offshore both east of Goleta Point and west of Coal Oil Point, and it has a minimum mapped length (onshore and offshore) of about $10 \mathrm{~km}$. The eastern offshore section of this fault dies out $5 \mathrm{~km}$ to the east of Goleta Point (fig. 1-2), in a zone of tight folding, The western offshore section of this fault is inferred to form a lineament that cuts outcrop of the Monterey Formation. The onland More Ranch Fault (Keller and Gurrola, 2000; Minor and others, 2009) does not obviously extend west beyond Coal Oil Point.

The regional pattern of faults and earthquakes occurring between 1932 and 2010 that have inferred or measured magnitudes greater than 2.0 are shown on Map C on sheet 9. Although locations have been provided by the CalTech network since 1932, significantly greater precision began in 1969 with installation of a USGS seismographic network (see, for example, Lee and Vedder, 1973; Sylvester, 2001; Southern California Earthquake Data Center, 2010). Epicentral data indicate that seismicity in the eastern and central Santa Barbara Channel is characterized by earthquake swarms, relatively frequent minor earthquakes, and infrequent major earthquakes.

Three significant earthquakes affected the Santa Barbara Channel area in 1812, 1857, and 1925, prior to the time covered by the Southern California Earthquake Data Center (2010) catalog; however, locations in the northern Santa Barbara Channel have been reported (Sylvester and others, 1970) for both the 1925 event (M6.3) and the largest earthquake ( M5.5, 7/1/1941), which is shown on Map C (sheet 9). In addition, Sylvester and others (1970) documented a swarm of 62 earthquakes (M2.5-M5.2) that occurred between 6/26/1968 and 8/3/1968, which also were located 10 to $15 \mathrm{~km}$ south (offshore) of Santa Barbara. The largest event in the Offshore of Coal Oil Point map area ( M4.1) occurred on 11/16/1958, a few kilometers northwest of Naples.

\section{Thickness and Depth to Base of Uppermost Pleistocene and Holocene Deposits}

Maps on sheet 9 show the thickness and the depth to base of uppermost Pleistocene and Holocene (post-LGM) deposits both for the Offshore of Coal Oil Point map area (Maps A, B) and, to establish regional context, for a larger area (about $115 \mathrm{~km}$ of coast) that extends from the vicinity of 
Hueneme Canyon northwest to the Refugio Beach area (Maps D, E). To make these maps, water bottom and depth to base of the LGM horizons were mapped from seismic-reflection profiles using Seisworks software. The difference between the two horizons was exported from Seisworks for every shot point as XY coordinates (UTM zone 11) and two-way travel time (TWT). The thickness of the post-LGM unit (Maps B, E) was determined by applying a sound velocity of $1,600 \mathrm{~m} / \mathrm{sec}$ to the TWT, resulting in thicknesses as great as $65 \mathrm{~m}$. The thickness points were interpolated to a preliminary continuous surface, overlaid with zero-thickness bedrock outcrops (see sheet 10), and contoured (Wong and others, 2012). Data within Hueneme Canyon were excluded from the contouring because the seismic-reflection data are too sparse to adequately image the highly variable changes in sediment thickness that characterize the canyon (Maps D, E).

Several factors required manual editing of the preliminary thickness maps to make the final product. The Red Mountain Fault Zone, Pitas Point Fault, and Oak Ridge Fault disrupt the sediment sequence in the region (Maps D, E, on sheet 9). The data points also are dense along tracklines (about 1 $\mathrm{m}$ apart) and sparse between tracklines (1-2 km apart), resulting in contouring artifacts. To incorporate the effect of the faults, to remove irregularities from interpolation, and to reflect other geologic information and complexity, the resulting interpolated contours were modified. Contour modifications and regridding were repeated several times to produce the final regional sediment-thickness map (Wong and others, 2012).

The depth-to-base data available from Seisworks were similarly processed and contoured; however, this preliminary dataset was set aside in favor of a surface determined by subtracting the modified thickness data from multibeam bathymetry collected separately (see sheet 1) and using 1,500 $\mathrm{m} / \mathrm{sec}$ for TWT in the water column. The depth of this surface in the Hueneme Canyon to Refugio Beach area ranges from 12 to 190 m (Map D on sheet 9; see also, Wong and others, 2012).

Five different "domains" of sediment thickness, which are bounded either by faults or by Hueneme Canyon, are recognized on the regional maps (Maps D, E on sheet 9): (1) north of the south strand of the Red Mountain Fault Zone; (2) between the south strand of the Red Mountain Fault Zone and the Pitas Point Fault; (3) between the Pitas Point and Oak Ridge Faults; (4) between the Oak Ridge Fault and Hueneme Canyon; and (5) south of Hueneme Canyon. Table 7-1 shows the area of these five domains, along with estimates of their mean sediment thickness and total sediment volume. These data highlight the contrast among three general zones of sediment thickness: (1) the uplifted, sediment-poor Santa Barbara shelf (domain 1; mean sediment thickness of $3.5 \mathrm{~m}$ ); (2) a transitional zone (domain 2; mean sediment thickness of $18.0 \mathrm{~m}$ ); and (3) the subsiding, sediment-rich delta and shelf offshore of the Ventura and Santa Clara Rivers and Calleguas Creek (domains 3, 4, and 5; mean sediment thicknesses of 39.2, 38.9, and $28.3 \mathrm{~m}$, respectively).

In the Offshore of Coal Oil Point map area, thickness data (Map B on sheet 9) reveal that the post-LGM section has a mean thickness of just $4.0 \mathrm{~m}$. Sediment is either notably lacking or it forms only a thin veneer over bedrock outcrops on the midshelf to outer shelf areas and in the nearshore near Goleta Point, Coal Oil Point, and Naples (fig. 1-2).

Three nearshore areas having a common inferred origin have sediment cover that is notably thicker. On the east map edge, about 1,500 m offshore, the Map B isopach reveals a depocenter that has as much as $15 \mathrm{~m}$ of post-LGM sediment (see also, fig. 5 on sheet 8). This depocenter, which has positive seafloor relief and also "delta-mouth bar" morphology (sheets 1,2 ), is characterized by a relatively flat (about $0.6^{\circ}$ ) upper surface and a steeper (about $3.7^{\circ}$ ), seaward-dipping front. This feature is aligned with, and is slightly west of, a network of streams (including San Jose Creek; fig. 1-2) that drain into Goleta Slough, and these coastal watersheds are the inferred sources of the sediment that makes up this "delta-mouth bar."

Two other nearshore depocenters farther west (Map B) are somewhat different. The first, about $3.6 \mathrm{~km}$ west of Coal Oil Point, is represented by a tapering wedge of sediment that progressively thins 
from about 15 to $0 \mathrm{~m}$, between 1,500 and 4,000 m offshore; this thick deposit is found at the combined mouths of three coastal watersheds, Tecolote Canyon, Winchester Canyon, and Ellwood Canyon (fig. 1-2), which are its inferred sediment sources. The second, westernmost nearshore depocenter (Map B), present about 1,400 m offshore of Naples, has as much as $17 \mathrm{~m}$ of post-LGM sediment (fig. 2 on sheet 8). This second deposit forms a bar that extends southward on the southwest flank of a submerged but protruding bedrock platform (see sheet 10 ); the bar has a gently dipping $\left(0.6^{\circ}\right)$ upper surface, which is continuous with the bedrock platform, and a more steeply dipping $\left(4.1^{\circ}\right)$ bar front. This area is offshore of the mouth of Dos Pueblos Canyon (fig. 1-2), which is the inferred sediment source. The bar is present only on the southwest side of the submerged bedrock platform, suggesting that sediment also may have been derived from more western watersheds and then transported westward until it was deposited on the updrift flank of the submerged bedrock protrusion.

Within California's State Waters, slightly thicker accumulations of post-LGM sediment are present locally on the upper slope, just below the shelf break. The thickest accumulation (about $15 \mathrm{~m}$ ) represents midslope landslide debris within the submarine Goleta landslide complex (Eichhubl and others, 2002; Fisher and others, 2005; Greene and others, 2006), as shown in figure 3 on sheet 8.

Table 7-1. Area, sediment-thickness, and sediment-volume data for California's State Waters in Santa Barbara Channel region, between Refugio Beach and Hueneme Canyon areas (domains 1-5), as well as in Offshore of Coal Oil Point map area.

[Data from within Hueneme Canyon were not included in this analysis]

\begin{tabular}{|l|c|c|c|}
\hline \multicolumn{3}{|c|}{ Regional sediment-thickness domains in Santa Barbara Channel region } \\
\hline & Area (km²) & $\begin{array}{c}\text { Mean sediment } \\
\text { thickness (m) }\end{array}$ & $\begin{array}{c}\text { Sediment volume } \\
\left(10^{6} \mathrm{~m}^{3}\right)\end{array}$ \\
\hline (1) Refugio Beach to south strand of Red Mountain Fault Zone & 357.8 & 3.5 & 1,266 \\
\hline (2) South strand of Red Mountain Fault Zone to Pitas Point Fault & 67.1 & 18.0 & 1,205 \\
\hline (3) Pitas Point Fault to Oak Ridge Fault & 68.6 & 39.2 & 2,688 \\
\hline (4) Oak Ridge Fault to Hueneme Canyon & 75.4 & 38.9 & 2,933 \\
\hline (5) South of Hueneme Canyon & 53.9 & 28.3 & 1,527 \\
\hline \multicolumn{1}{|c|}{ Sediment thickness in Offshore of Coal Oil Point map area } \\
\hline Offshore of Coal Oil Point map area & 104.4 & 4.0 & 417 \\
\hline
\end{tabular}




\title{
Chapter 8. Geologic and Geomorphic Map of the Offshore of Coal Oil Point Map Area (Sheet 10)
}

\author{
By James E. Conrad, Samuel Y. Johnson, Andrew C. Ritchie, H. Gary Greene, Gordon G. Seitz, and Carlos I. \\ Gutierrez
}

\section{Geologic and Geomorphic Summary}

Marine geology and geomorphology were mapped in the Offshore of Coal Oil Point map area from approximate Mean High Water (MHW) to the 3-nautical-mile limit of California's State Waters. MHW is defined at an elevation of $1.33 \mathrm{~m}$ above the North American Vertical Datum of 1988 (NAVD 88) (Weber and others, 2005). Offshore geologic units were delineated on the basis of integrated analyses of adjacent onshore geology with multibeam bathymetry and backscatter imagery (sheets 1,2 , 3), seafloor-sediment and rock samples (Reid and others, 2006), digital camera and video imagery (sheet 6), and high-resolution seismic-reflection profiles (sheet 8).

The onshore geology was compiled from Dibblee (1981, 1987a,b) and Minor and others (2009). Unit ages, which are largely from Minor and others (2009), reflect local stratigraphic relations.

The offshore part of the map area largely consists of a gently offshore-dipping (less than $1^{\circ}$ ) shelf underlain by sediments derived primarily from relatively small coastal watersheds that drain the Santa Ynez Mountains (fig. 1-2). Shelf deposits are primarily sand (Qms) at depths less than about 35 to $50 \mathrm{~m}$, and they are finer grained sediment such as very fine sand, silt, and clay (Qmsf) from depths of 35 to 50 m southward to the shelf break at a depth of about $90 \mathrm{~m}$. The boundary between units Qms and Qmsf is based on observations and extrapolation from sediment sampling (see, for example, Reid and others, 2006) and camera ground-truth surveying (see sheet 6). It is important to note that the boundary between units Qms and Qmsf should be considered transitional and approximate and is expected to shift as a result of seasonal- to annual- to decadal-scale cycles in wave climate, sediment supply, and sediment transport.

Fine-grained deposits that are similar to unit Qmsf also are mapped at water depths greater than $90 \mathrm{~m}$, below the shelf break on the upper slope; however, here they are identified as a separate unit (unit Qmsl) because of their location below the distinct shelf-slope geomorphologic break.

Coarser grained, marine deposits (coarse sand to boulders) of units Qmsc, Qmscl, and Qsc are recognized on the basis of their high acoustic backscatter (sheet 3), their ground-truth-survey imagery (sheet 6), and, in some cases, their moderate seafloor relief (sheets 1, 2). This coarse-grained facies is linked either to the mouths of steep coastal watersheds or to adjacent seafloor bedrock outcrops, and the deposits generally represent wave-winnowed lags of deltaic sediment. Two distinct lobes of coarsegrained sediment (unit Qmscl), present in deeper water (about $50 \mathrm{~m}$ ) near the west edge of the map area, may similarly represent winnowed deltaic deposits that formed at lower sea levels during the latest Pleistocene or early Holocene. An isolated patch of clast-supported cobbles (unit Qsc), which rests on bedrock south of Coal Oil Point at a water depth of $70 \mathrm{~m}$, also may have been deposited at lower sea levels during the late Pleistocene.

Offshore bedrock exposures are mapped as either the Miocene Monterey Formation (Tm, Tmu, Tmm), the upper Miocene and lower Pliocene Sisquoc Formation (Tsq), or the undivided Quaternary and Tertiary bedrock (QTbu) or undivided Tertiary bedrock (Tbu) units on the basis of the confidence in extending the onshore mapping of Minor and others (2009) offshore. Midshelf to outer shelf bedrock exposures are all mapped as undivided units; however, offshore sampling data (see, for example, Kunitomi and others, 1998), as well as regional cross sections that are constrained by petroleum exploration data and sampling (Redin, 2005; Redin and others, 2005), have suggested that these seafloor outcrops predominantly are upper Miocene and Pliocene strata. These rocks have been uplifted in a 
large, regional, internally warped, south-dipping homocline that formed above the blind, north-dipping Pitas Point-North Channel Fault system; the fault tip is inferred to lie beneath the continental slope, about 6 to $7 \mathrm{~km}$ offshore.

Bedrock is, in some places, overlain by a thin (less than $1 \mathrm{~m}$ ?) veneer of sediment, recognized on the basis of high backscatter, flat relief, continuity with moderate- to high-relief bedrock outcrops, and (in some cases) high-resolution seismic-reflection data; these areas, which are mapped as composite units Qms/Tu, Qms/Tsq, Qms/Tmu, Qms/Tmm, Qms/Tm, Qms/Tbu, or Qmsf/QTbu, are interpreted as ephemeral sediment layers that may or may not be continuously present, whose presence or absence is a function of the recency and intensity of storm events, seasonal and (or) annual patterns of sediment movement, or longer term climate cycles.

The Offshore of Coal Oil Point map area includes the upper part of the large $\left(130 \mathrm{~km}^{2}\right)$, welldocumented submarine Goleta landslide complex (Eichhubl and others, 2002; Fisher and others, 2005; Greene and others, 2006). Greene and others (2006) reported that the complex, which measures $14.6 \mathrm{~km}$ long and $10.5 \mathrm{~km}$ wide and extends from water depths of 90 to $574 \mathrm{~m}$, has displaced about $1.75 \mathrm{~km}^{3}$ of landslide debris during the Holocene; they described it as a compound, multiphase submarine landslide that contains both surficial slump blocks and mud flows, in three distinct segments (west, central, and east lobes). Each segment consists of a distinct headwall scarp (units Qglwh, Qglch, Qgleh), a downdropped head block (units Qglwb, Qglcb, Qgleb), and several composite slide-debris lobes (units Qglw5, Qfglw4, Qglw3, Qglw2, Qglw1, Qglc4, Qglc3, Qglc2a, Qglc2, Qfle5, Qgle4, Qgle3, Qgle2). The geologic and geomorphologic map on sheet 10 shows the upper approximately $3 \mathrm{~km}$ of this landslide complex; in addition, seismic-reflection profile SB-145 (fig. 3 on sheet 8), which crosses the east lobe of the landslide complex, illustrates its subsurface characteristics (see chapter 7). The landslide source is inferred to be Pleistocene-age, shelf-edge deltaic sediments deposited during Quaternary sealevel lowstands, and Fisher and others (2005) suggested that the youngest landslides formed about 8,000 to 10,000 years ago.

The Santa Barbara Channel region, including the map area, has a long history of hydrocarbon production (Barnum, 1998) that began in 1928 with discovery of the Ellwood oil field (see sheet 11). Subsequent discoveries in the offshore part of the map area include the South Ellwood offshore oil field, the Coal Oil Point oil field, and the Naples oil and gas field (see sheet 11; see also, Brickey, 1998; Galloway, 1998). Oil and gas are mainly sourced by the Miocene Monterey Formation; the reservoirs are in the Vaqueros Formation, the Rincon Shale, and the Monterey Formation. Development of the South Ellwood offshore oil field began in 1966 from platform "Holly" (see sheet 11), which was the last platform to be installed in California's State Waters. Debris and infrastructure associated with platform "Holly,” as well as with seep containment devices (“seep tents”), are mapped as unit pd.

Hornafius and others (1999) described "the world's most spectacular marine hydrocarbon seeps” in the Coal Oil Point map area, and these seeps release an estimated 36 metric tons of methane and 17 metric tons reactive organic gas (ethane, propane, butane, and higher hydrocarbons) per day. Areas of grouped to solitary pockmarks (unit Qmp) caused by such gas seeps are common features. In addition, numerous asphalt (tar) deposits (unit Qas) associated with hydrocarbon seeps and gas vents are mapped both onshore and offshore. The offshore deposits, which have been confirmed with seafloor video observations (see sheet 11), often are localized along bedrock structures such as faults or the crests of anticlines, forming bathymetric features that are morphologically similar to bedrock outcrops but are distinguished from them on the basis of their low acoustic backscatter. Although many such asphalt deposits are too small to be shown on the map, the larger deposits can cover as much as several hundred square meters. The relative proportions of all offshore map units are shown in table 8-1. 
Table 8-1. Areas and relative proportions of offshore geologic map units in Offshore of Coal Oil Point map area.

\begin{tabular}{|c|c|c|c|}
\hline Map Unit & Area $\left(\mathrm{m}^{2}\right)$ & Area $\left(\mathrm{km}^{2}\right)$ & Percent of total area \\
\hline \multicolumn{4}{|c|}{ Marine sedimentary units } \\
\hline $\mathrm{pd}$ & 42,344 & 0.04 & 0.02 \\
\hline Qas & 737,954 & 0.74 & 0.42 \\
\hline Qmp & $5,787,296$ & 5.79 & 3.29 \\
\hline Qms & $35,001,892$ & 35.00 & 19.89 \\
\hline Qmsf & $38,634,837$ & 38.63 & 21.95 \\
\hline Qmsl & $16,453,320$ & 16.45 & 9.35 \\
\hline Qmsc & $1,812,709$ & 1.81 & 1.03 \\
\hline Qmscl & 291,397 & 0.29 & 0.17 \\
\hline Qsc & 60,999 & 0.06 & 0.03 \\
\hline Total, sedimentary units & $98,822,748$ & 98.82 & 56.15 \\
\hline \multicolumn{4}{|c|}{ Goleta landslide complex units } \\
\hline \multicolumn{4}{|c|}{ East lobe } \\
\hline Qgleh & 4,209,726 & 4.21 & 2.39 \\
\hline Qgleb & 3,392,955 & 3.39 & 1.93 \\
\hline Qgle5 & 653,639 & 0.65 & 0.37 \\
\hline Qgle4 & 3,023,159 & 3.02 & 1.72 \\
\hline Qgle3 & 3,895,128 & 3.90 & 2.21 \\
\hline Qgle2 & $1,100,553$ & 1.10 & 0.63 \\
\hline \multicolumn{4}{|c|}{ Central lobe } \\
\hline Qglch & $2,467,218$ & 2.47 & 1.40 \\
\hline Qglcb & $2,391,690$ & 2.39 & 1.36 \\
\hline Qglc4 & $1,063,277$ & 1.06 & 0.60 \\
\hline Qglc3 & $5,516,083$ & 5.52 & 3.13 \\
\hline Qglc2a & 889,784 & 0.89 & 0.51 \\
\hline Qglc2 & $3,527,310$ & 3.53 & 2.00 \\
\hline \multicolumn{4}{|c|}{ West lobe } \\
\hline Qglwh & $1,309,542$ & 1.31 & 0.74 \\
\hline Qglwb & $2,282,160$ & 2.28 & 1.30 \\
\hline Qglw5 & 647,151 & 0.65 & 0.37 \\
\hline Qglw4 & $4,417,467$ & 4.42 & 2.51 \\
\hline Qglw3 & $4,669,654$ & 4.67 & 2.65 \\
\hline Qglw2 & 347,472 & 0.35 & 0.20 \\
\hline Qglw1 & 385,537 & 0.39 & 0.22 \\
\hline Total, Goleta landslide complex units & $46,189,507$ & 46.19 & 26.24 \\
\hline
\end{tabular}


Table 8-1. Areas and relative proportions of offshore geologic map units in Offshore of Coal Oil Point map area.-Continued

\begin{tabular}{|l|r|r|r|}
\hline \multicolumn{1}{|c|}{ Map Unit } & \multicolumn{1}{c|}{ Area $\left(\mathbf{m}^{2}\right)$} & Area $\left(\mathbf{k m}^{2}\right)$ & Percent of total area \\
\hline \multicolumn{2}{|c|}{ Marine bedrock and (or) shallow bedrock units } \\
\hline Qmsf/QTbu & $1,778,038$ & 1.78 & 1.01 \\
\hline Qms/Tbu & $3,022,241$ & 3.02 & 1.72 \\
\hline Qms/Tm & 399,229 & 0.40 & 0.23 \\
\hline Qms/Tmm & 16,063 & 0.02 & 0.01 \\
\hline Qms/Tmu & 6,254 & 0.01 & 0.00 \\
\hline Qms/Tsq & 309,344 & 0.31 & 0.18 \\
\hline Qms/Tu & 5,957 & 0.01 & 0.00 \\
\hline QTbu & $6,784,966$ & 6.78 & 3.86 \\
\hline Tbu & $14,372,750$ & 14.37 & 8.17 \\
\hline Tsq & $2,819,763$ & 2.82 & 1.60 \\
\hline Tm & $1,117,535$ & 1.12 & 0.63 \\
\hline Tmm & 15,037 & 0.02 & 0.01 \\
\hline Tr & 334,747 & 0.33 & 0.19 \\
\hline Total, bedrock units & $30,981,924$ & 30.98 & 17.60 \\
\hline Total, Offshore of Coal Oil Point map area & $175,994,179$ & 175.99 & 100.00 \\
\hline
\end{tabular}




\section{DESCRIPTION OF MAP UNITS}

\section{OFFSHORE GEOLOGIC AND GEOMORPHIC UNITS}

[Note that, where older units (typically, bedrock) are overlain by thin ( $<1 \mathrm{~m}$ thick) Quaternary deposits, composite units are mapped. These composite units, which are shown with gray or white stipple pattern on older unit, are designated by composite label indicating both overlying sediment cover and lower (older) unit, separated by slash (for example, Qms/Tbu indicates that thin sheet of Qms overlies Tbu)]

\section{NEARSHORE, SHELF, AND UPPER SLOPE}

pd Oil-platform debris (late Holocene)—Mixed accumulations of construction material, coarse sediment, and shell debris, in two small (less than 7,500 $\mathrm{m}^{2}$ ) seafloor outcrops associated with platform "Holly" and hydrocarbon-seep containment devices ("seep tents")

Qms Marine nearshore and shelf deposits (late Holocene)-Predominantly sand; ripples common. Found on gently seaward-dipping (about $1^{\circ}$ ) surface that extends from nearshore to water depths of about 35 to $50 \mathrm{~m}$

Qmsc Coarse-grained marine nearshore and shelf deposits (late Holocene)_Predominantly coarse sand and gravel to boulders. Found locally in nearshore to inner shelf (water depths of 10 to $40 \mathrm{~m}$ ) environments adjacent to bedrock outcrops or at mouths of steep coastal watersheds. Recognized primarily on basis of high acoustic backscatter and low to moderate relief

Qmsf Fine-grained marine shelf deposits (late Holocene)—Predominantly clay, silt, and very fine sand, commonly bioturbated. Found on gently seaward-dipping $\left(\right.$ about $1^{\circ}$ ) surface, at water depths greater than about 35 to $50 \mathrm{~m}$ and less than $90 \mathrm{~m}$

Qmsl Marine upper slope deposits (late Holocene)—Predominantly clay, silt, and very fine sand, commonly bioturbated. Found below shelf break on moderately seaward-dipping (about $5^{\circ}$ ) surface, at water depths greater than $90 \mathrm{~m}$

Qmp Marine pockmarks (late Holocene) —Sand and mud, forming pockmarks primarily on outer shelf and upper slope, in water depths greater than $75 \mathrm{~m}$. Pockmarks are predominantly grouped or, less commonly, solitary; are circular to elliptical; range in size from 50 to $150 \mathrm{~m}$ along their long axis; typically are 20 to $40 \mathrm{~cm}$ deep; and commonly have central cone as much as $150 \mathrm{~cm}$ high

Qas Asphalt deposits (Holocene) — Asphalt (tar); weathered and biodegraded oil derived from underlying or nearby natural hydrocarbon seeps. Most commonly found along or adjacent to faults or anticlinal axes

Qmscl Marine shelf-sediment lobes (Holocene or latest Pleistocene)—Predominantly sand and gravel. Forms midshelf (water depths of 40 to $60 \mathrm{~m}$ ) lobate deposits as much as $1 \mathrm{~km}$ long and $300 \mathrm{~m}$ wide; lobes commonly have relief of 30 to $50 \mathrm{~cm}$ above surrounding seafloor. Present offshore of mouths of steep coastal watersheds

Qsc Marine or nonmarine coarse-grained deposits (late Pleistocene?)-Isolated outcrop of consolidated or semiconsolidated, flat-lying sedimentary strata, at least partly conglomeratic. Unconformably overlies folded marine sedimentary rocks of the undivided Pliocene and Miocene bedrock unit (Tbu). Deposit is 2 to $3 \mathrm{~m}$ thick

QTbu Bedrock, undivided (Pleistocene, Pliocene, and Miocene)—Predominantly mudstone and siltstone; includes conglomeratic sandstone. Stippled areas (composite unit Qmsf/QTbu) indicate where thin sheets of Qmsf overlie unit 
Tbu Bedrock, undivided (Pliocene and Miocene) —Undivided strata of the Pico, Sisquoc, and Monterey Formations. Stippled areas (composite unit Qms/Tbu) indicate where thin sheets of Qms overlie unit

Tsq Sisquoc Formation (early Pliocene and late Miocene)—Mainly diatomaceous mudstone and shale; also includes conglomerate and subordinate dolomite. Stippled areas (composite unit Qms/Tsq) indicate where thin sheets of Qms overlie unit

Tu Unnamed mudstone (late Miocene) - Marine mudstone, shale, and porcelanite, with subordinate dolomite and phosphatic pebble conglomerate. Shown only as composite (stippled) unit Qms/Tu, where thin sheets of Qms overlie unit

Tm Monterey Formation, undivided (Miocene) — Undivided, predominantly well-bedded, siliceous and calcareous mudstone and shale; may include strata of the unnamed mudstone unit (Tu), exposed in adjacent coastal (onshore) outcrops. Stippled areas (composite unit Qms/Tm) indicate where thin sheets of Qms overlie unit

Tmu Upper siliceous unit (late Miocene)—Mainly marine, diatomaceous and siliceous mudstone and shale, with subordinate dolomite and porcelanite. Shown only as composite (stippled) unit Qms/Tmu, where thin sheets of Qms overlie unit

Tmm Middle shale unit (late and middle Miocene) — Mainly marine shale, mudstone, dolomite, porcelanite, phosphorite, and subordinate tuff. Stippled areas (composite unit Qms/Tmm) indicate where thin sheets of Qms overlie unit

$\operatorname{Tr} \quad$ Rincon Shale (early Miocene)—Mostly mudstone, with subordinate dolomite, siliceous shale, sandstone, and tuff

\section{GOLETA LANDSLIDE COMPLEX}

[Goleta landslide complex is compound submarine landslide, part of which is mapped in southwestern part of Coal Oil Point map area. Consists of three separate slide sequences, mapped as east, central, and west lobes. Landslide deposits are divided into the following subunits, on basis of subdivision by Greene and others (2006), who recognized several phases ("generations") of marine-landslide deposits, first of which is mapped mainly south of map area]

\section{West Lobe}

Qglwh Goleta landslide headwall, west lobe (Holocene)—Unconsolidated marine sediment overlying intact marine sedimentary bedrock (units QTbu and Tbu); exposed in slide surface of landslide

Qglwb Goleta landslide head block, west lobe (Holocene) —Intact to semi-intact slump blocks at base of headwall scarp, probably consisting of units QTbu and Tbu; in most places, mantled by as much as $50 \mathrm{~m}$ of ponded and draped marine sediment

Qglw5 Goleta landslide fifth-phase flow deposit, west lobe (Holocene) - Secondary marinelandslide deposits consisting of mud and sand; postdates primary four-phase landslide complex. Derived from failure of sidewall scarp of main landslide complex

Qglw4 Goleta landslide fourth-phase flow deposit, west lobe (Holocene) —Landslide deposits consisting of mud and sand; fourth primary marine-landslide flow unit in landslide complex

Qglw3 Goleta landslide third-phase flow deposit, west lobe (Holocene) —Landslide deposits consisting of mud and sand; third primary marine-landslide flow unit in landslide complex

Qglw2 Goleta landslide second-phase flow deposit, west lobe (Holocene)—Landslide deposits consisting of mud and sand; second primary marine-landslide flow unit in landslide complex 
Qglw1 Goleta landslide initial flow deposit, west lobe (Holocene)—Landslide deposits consisting of mud and sand; first primary marine-landslide flow unit in landslide complex

Central Lobe

Qglch Goleta landslide headwall, central lobe (Holocene)—Unconsolidated marine sediment overlying intact marine sedimentary bedrock (units QTbu and Tbu); exposed in slide surface of landslide. In upper slide-scarp breakaway, unit typically is thin layer but, along exposed slide surface, is as thick as $30 \mathrm{~m}$ (of sediment?)

Qglcb Goleta landslide head block, central lobe (Holocene) - Intact to semi-intact slump blocks at base of headwall scarp, probably consisting of units QTbu and Tbu; in most places, mantled by as much as $50 \mathrm{~m}$ of ponded and draped marine sediment

Qglc4 Goleta landslide fourth-phase flow deposit, central lobe (Holocene) — Landslide deposits consisting of mud and sand; fourth primary marine-landslide flow unit in landslide complex

Qglc3 Goleta landslide third-phase flow deposit, central lobe (Holocene)—Landslide deposits consisting of mud and sand; third primary marine-landslide flow unit in landslide complex

Qglc2a Goleta landslide, secondary failure of second-phase flow deposit, central lobe (Holocene) — Landslide deposits consisting of mud and sand. Secondary slope failure following second (but before third) primary marine-landslide flow unit in landslide complex

Qglc2 Goleta landslide second-phase flow deposit, central lobe (Holocene)_Landslide deposits consisting of mud and sand; second primary marine-landslide flow unit in landslide complex

\section{East Lobe}

Qgleh Goleta landslide headwall, east lobe (Holocene)—Unconsolidated marine sediment overlying intact marine sedimentary bedrock (units QTbu and Tbu); exposed in slide surface of landslide. In upper slide-scarp breakaway, unit typically is thin layer but, along exposed slide surface, is as thick as $30 \mathrm{~m}$ (of sediment?)

Qgleb Goleta landslide head block, east lobe (Holocene)—Intact to semi-intact slump blocks at base of headwall scarp, probably consisting of units QTbu and Tbu; in most places, mantled by as much as $50 \mathrm{~m}$ of ponded and draped marine sediment

Qgle5 Goleta landslide fifth-phase flow deposit, east lobe (Holocene) — Landslide deposits consisting of mud and sand. Secondary marine-landslide deposit; postdates main, four-phase landslide complex

Qgle4 Goleta landslide fourth-phase flow deposit, east lobe (Holocene)—Landslide deposits consisting of mud and sand; fourth primary marine-landslide flow unit in landslide complex

Qgle3 Goleta landslide third-phase flow deposit, east lobe (Holocene)—Landslide deposits consisting of mud and sand; third primary marine-landslide flow unit in landslide complex

Qgle2 Goleta landslide second-phase flow deposit, east lobe (Holocene)—Landslide deposits consisting of mud and sand; second primary marine-landslide flow unit in landslide complex 


\section{ONSHORE GEOLOGIC AND GEOMORPHIC UNITS}

[Units are compiled from Dibblee (1981, 1987a,b) and Minor and others (2009); unit ages, which are largely from Minor and others (2009), reflect local stratigraphic relations]

af Artificial fill (late Holocene)_Engineered and (or) nonengineered

$\mathrm{Qb} \quad$ Beach deposits (late Holocene)-Unconsolidated, loose, fine- to coarse-grained sand; well sorted. Mapped in coastal band from shoreline to highest elevation of swash zone

Qds Dune sand (Holocene)_-Unconsolidated wind-blown sand forming hummocky coastal dunes northwest of Coal Oil Point

Qes Coastal-estuarine deposits (Holocene) — Locally organic-rich clay, silt, and subordinate sand. Mapped primarily in tidally influenced environments

Qas Asphalt deposits (Holocene)—Black asphalt (tar) that represents weathered and biodegraded oil derived from nearby natural hydrocarbon seeps. Typically found near asphalt-filled fractures in bedrock exposed in sea cliffs

Qa Channel alluvium (Holocene) - Unconsolidated sediment, primarily gravel, pebbles, and boulders, in floors and banks of active, modern stream channels. Commonly incised as much as $5 \mathrm{~m}$ into alluvial deposits of associated floodplain (unit Qyf)

Qyd Debris-flow deposits (Holocene and late Pleistocene)—Massive, weakly consolidated rock-debris breccia; derived from upslope rock units. Mainly located along lower flanks of Santa Ynez Mountains

Qyf Alluvium and colluvium (Holocene and late Pleistocene)-Weakly consolidated silt, sand, and gravel deposits of modern drainages, piedmont alluvial fans, and floodplains

Qc Colluvium (Holocene and late Pleistocene)-Weakly consolidated, poorly stratified, and poorly sorted deposits that mantle gentle to moderate slopes; formed by weathering and downslope movement of nearby bedrock

QIs Landslide deposits (Holocene to middle Pleistocene)-Deposits of diverse slopemovement processes, ranging from poorly sorted, disrupted mixtures of rock fragments and soil to relatively intact bedrock slump blocks. Largest landslide deposits may be as thick as $60 \mathrm{~m}$

Qomp Marine-terrace deposits (late Pleistocene)-Basal, about 1-m-thick, weakly to moderately well consolidated, variably stratified, fossiliferous gravel, sand, and silt overlying nonmarine eolian, alluvial, and colluvial deposits; deposited as marine intertidal, beach, and estuarine deposits. Unit, which rests on elevated, marine wave-cut platforms, forms single terraces or flights of terraces that, in Santa Barbara coastal region, range in elevation from 10 to $130 \mathrm{~m}$ and in age from about 120 ka (oxygenisotope stage 5) to $40 \mathrm{ka}$ (substage 3) (Gurrola and others, 2014)

Qoa2 Intermediate-age alluvial deposits (late Pleistocene)—Weakly consolidated, stratified silt, sand, and gravel that form low, rounded, moderately well dissected terraces and piedmont alluvial fans. Found at elevations higher than modern coastal piedmont surface

Qoa1 Older alluvial deposits (late and middle Pleistocene)—Moderately well consolidated, crudely stratified, poorly sorted sand and sandstone, gravel, conglomerate, breccia, and rare interbeds of clay, silt, and mudstone; makes up proximal to distal facies of alluvial fans shed from Santa Ynez Mountains. Forms dissected, gently south-sloping elevated terraces, interfluvial caps, and other erosional remnants as thick as $35 \mathrm{~m}$

Qsb Santa Barbara Formation (middle and early Pleistocene)_Chiefly marine, pale-gray, pale-buff, and pale-tan, friable, bioturbated, and massive sandstone; includes subordinate interbeds and intervals of shale, siltstone, and silty to clayey sandstone. 
Contains diverse assemblage of marine invertebrate fossils. Rare conglomeratic lenses become more common upsection, and uppermost part of unit locally interfingers with older alluvial deposits (unit Qoa1). Maximum exposed thickness, about $300 \mathrm{~m}$

QTst Unnamed siltstone unit east of Goleta Pier (Pleistocene and Pliocene?) —-Massive and extensively bioturbated siltstone, mudstone, and silty sandstone. Contains marine fossils. Exposed thickness, about $45 \mathrm{~m}$

Tsq Sisquoc Formation (early Pliocene and late Miocene)—Marine, tan- to white-weathering, diatomaceous mudstone and shale, conglomerate, and subordinate dolomite. Unit distinguished by thick beds of conglomerate that contain angular clasts (commonly as much as $1 \mathrm{~m}$ across; some blocks as large as $10 \mathrm{~m}$ ) derived from the Monterey Formation. Both top and base are erosional unconformities

Tu Unnamed mudstone (late Miocene) - Marine mudstone, shale, and porcelanite, with subordinate dolomite and phosphatic pebble conglomerate

Monterey Formation (Miocene) - Marine, predominantly well-bedded, siliceous and calcareous mudstone and shale, with subordinate porcelanite and dolomite. Contains abundant microfossils. Deposited at water depths ranging from upper to lower bathyal (150-2,000 m). In map area, the Monterey Formation is divided into three subunits (Tmu, Tmm, Tml), distinguished from each other by lithology and age; in addition, lower unit (Tml) includes intraformational breccia subunit (Tmlb). Maximum composite thickness in this region estimated to be about $830 \mathrm{~m}$

Tmu Upper siliceous unit (late Miocene) - East of Eagle Canyon (fig. 1-2), consists mainly of marine, white- to tan-weathering diatomaceous mudstone and shale, with subordinate dolomite and porcelanite. West of Eagle Canyon, consists mainly of thinbedded, light-brown-weathering siliceous mudstone and shale, porcelanite, and subordinate dolomite. Thickness ranges from about 50 to $250 \mathrm{~m}$

Tmm Middle shale unit (late and middle Miocene)-Marine, white-weathering shale, mudstone, dolomite, porcelanite, phosphorite, and subordinate tuff. Includes prominent, at least 20- to 30-m-thick, submarine-slump deposit in sea cliff near mouth of Eagle Canyon, in western part of map area. Thickness estimated to range from 70 to $180 \mathrm{~m}$

Tml Lower calcareous unit (middle and early Miocene)—Calcareous, siliceous, and phosphatic, white- to tan-weathering mudstone and shale, with subordinate dolomite, porcelanite, breccia, glauconitic sandstone, and tuff. In places, unit contains intraformational deformation (including breccia) that may have formed by gravitational slumping shortly after deposition. Thickness, as much as $250 \mathrm{~m}$

Tmlb Breccia unit (middle? and early Miocene) - Intraformational breccia exposed on sea cliff near mouth of Dos Pueblos Canyon (fig. 1-2). Contains clasts of calcareous mudstone and dolomite. About $30 \mathrm{~m}$ thick

$\operatorname{Tr} \quad$ Rincon Shale (early Miocene)—Marine, primarily massive or thick-bedded, light-brownweathering mudstone, with subordinate dolomite, siliceous shale, sandstone, and tuff. Mudstone is bioturbated and massive, is pervasively hackly fractured, and locally contains abundant microfossils. Single or multiple white-weathering tuff layers limited to upper $10 \mathrm{~m}$

Trs Siliceous shale interval (early Miocene)-Marine, thin-bedded, white- to pale-grayweathering siliceous shale; resembles siliceous-shale intervals within the Monterey Formation. Found about $60 \mathrm{~m}$ stratigraphically below top of the Rincon Shale

Tv Vaqueros Formation (late Oligocene)-Shallow-marine, massive and bioturbated, 
resistant, light-tan-weathering sandstone. Uppermost part consists of thinly interbedded sandstone, siltstone, and mudstone; base typically marked by 50 - to 150-cm-thick, thinly bedded, calcareous conglomerate that contains abundant fossilshell fragments

Sespe Formation (Oligocene and late Eocene) - Nonmarine, fluvial, maroon, reddishbrown, and greenish- to pinkish-gray sandstone, mudstone, and conglomerate. In Santa Barbara coastal region, divided into three subunits (Tspu, Tspm, Tspl), distinguished from each other mainly by differences in stratigraphic position, lithology, provenance, and age; intraformational unconformity, representing depositional hiatus lasting much or all of early Oligocene time, separates lower (Tspl) and middle (Tspm) subunits. Composite thickness ranges from about 700 to more than $1,500 \mathrm{~m}$

Tspu Upper sandstone and mudstone unit (late Oligocene)_-Interbedded sandstone, siltstone, and mudstone; weathers to various shades of maroon, buff, pale green, tan, and gray. Proportions of different sedimentary rock types vary both laterally and vertically throughout section. Sandstones commonly are broadly lenticular, laminated, and thin to thick bedded. Thickness, as much as $600 \mathrm{~m}$ in map area

Tspm Middle conglomerate and sandstone unit (Oligocene)_-Interbedded conglomerate, sandstone, and mudstone; weathers to various shades of maroon, tan, and palegreenish gray. Proportions of different sedimentary rock types vary both laterally and vertically throughout section. Polymict conglomerate clasts include abundant chert and lithic sandstone, likely derived from Franciscan Complex source terranes. Thickness, as much as $230 \mathrm{~m}$ in map area

Tspl Lower conglomerate and sandstone unit (early Oligocene? and late Eocene)Interbedded conglomerate, conglomeratic sandstone, sandstone, mudstone, and minor shale; mostly weathers to various distinctive shades of salmon gray, reddish gray, pale-pinkish gray, and tan. Proportions of different sedimentary rock types vary both laterally and vertically throughout section. Sandstones and conglomerates are resistant and form hogbacks. Sandstones commonly are arkosic; conglomerates are polymict, containing abundant rounded quartzitic, granitoid, metamorphic-rock, and volcanic-rock clasts, likely derived from Mojave Desert source terranes. Thickness, as much as $150 \mathrm{~m}$ in map area

Tcw Coldwater Sandstone (late? and middle Eocene)—Shallow-marine, thin- to thick-bedded sandstone that weathers to distinctive pale shades of buff, yellow, tan, and brown, with subordinate interbeds and thin intervals of gray, olive-gray, and greenish-gray siltstone, shale, and mudstone. Sandstone beds are resistant and form hogbacks where steeply dipping. Upper part is locally conglomeratic and rich in fossil oyster shells. Within region, about 750 to $1,000 \mathrm{~m}$ thick

Ts Sacate Formation (Eocene)-Marine, dark-gray micaceous siltstone and shale, with interbeds of hard arkosic sandstone (Dibblee, 1981)

Tsa Sandstone unit (Eocene)-Marine, light-gray to tan arkosic sandstone

Tcd Cozy Dell Shale (Eocene)-Marine, dark-gray, argillaceous to silty micaceous shale, with minor light-gray to tan arkosic sandstone

Tcds Sandstone interval (Eocene) - Marine, light-gray to tan arkosic sandstone, with minor interbeds of gray micaceous shale 


\title{
Chapter 9. Natural Offshore Hydrocarbon Seepage and Related Tarball Accumulation in the Offshore of Coal Oil Point Map Area (Sheet 11)
}

\author{
By Thomas D. Lorenson, Florence L. Wong, Ira Leifer, Frances D. Hostettler, Kenneth E. Peters, Keith A. \\ Kvenvolden, Robert J. Rosenbauer, and Grace Fong
}

The Santa Barbara Channel has a rich recorded history of hydrocarbon seepage; the Coal Oil Point map area includes the Coal Oil Point seep field, one of the most prolific seep fields in the world (Landes, 1973). The native Chumash Indians used the asphalt (tar), which is biodegraded and weathered oil, found in the map area for a variety of purposes, including waterproofing boats and gluing arrowheads to shafts (Galloway, 1998). Between the 16th and 18th centuries, several European explorers noted the presence of petroleum within the area of the future Santa Barbara County, and they also described oil slicks and surfacing bubbles offshore. Asphalt mining flourished within Santa Barbara County during the mid-1800s, and its products were used to pave the streets of San Francisco and Santa Barbara (Galloway, 1998). During the 1920s and 1930s, the Ellwood oil field, located just west of Coal Oil Point (fig. 1-2), was drilled in shallow waters from more than sixteen oil piers (Bartlett, 1998). During the next three decades, wells were drilled from both piers and submarine platforms. Production of the South Ellwood oil field began in 1967 with the construction of platform "Holly" (Galloway, 1998), and this production continues to the present day (2014). However, the wells in the eastern and western parts of the original Ellwood oil field were abandoned by 1971 and 1993, respectively (Bartlett, 1998).

The Coal Oil Point seep field produces a wide diversity of oil- and gas-seepage rates. Studies have quantified seep area (see, for example, Allen and others, 1970; Fischer and Stevenson, 1973) and emission fluxes (see, for example, Hornafius and others, 1999; Quigley and others, 1999; Clark and others, 2000) using sonar techniques, ocean chemistry, and direct gas capture (by floating buoys). Fischer and Stevenson (1973), who recorded changes in seepage on decadal time scales in the Coal Oil Point map area, noted a significant decrease in the number of seepage areas between 1946 and 1973, attributable to offshore oil production from platform "Holly." Starting around the year 2000, the seeps have been mapped using sonar images, and the seepage flux has been semiquantified from both sonar and direct gas capture, using a flux buoy (Washburn and others, 2001). Those estimates and others indicate that approximately $15,000 \mathrm{~m}^{3}$ per day of gas escapes into the atmosphere from about $3 \mathrm{~km}^{2}$ of seafloor (Hornafius and others, 1999), and roughly an equal amount dissolves into the coastal ocean (Clark and others, 2000). Using data collected in 1973 and 1995, Quigley and others (1999) recorded a decrease in both the area and the number of seeps within $1.5 \mathrm{~km}$ of platform "Holly," which they attributed to oil production from "Holly."

In the Coal Oil Point map area, seeps are located above a series of anticlines (see sheet 10 of this report) along three trends: the inner trend (at about 20-m water depth) includes "Shane" and "IV Super" seeps; the middle trend (at about 40-m water depth) includes the "Horseshoe" and "Trilogy" seeps; and the outer trend (at about 70-m water depth) includes the "La Goleta” and "Seep Tent” seeps.

The map on sheet 11 shows known hydrocarbon-seepage sites that have been integrated with oilsource chemical fingerprinting, compiled during a 10-year study that linked beach tarballs to their offshore sources. The study was conducted by the U.S. Geological Survey, in conjunction with the Bureau of Ocean Energy Management (formerly, the Minerals Management Service), the County of Santa Barbara Energy Division, and the University of California, Santa Barbara. The approach was to (1) document the locations of naturally occurring seep oils or tar; (2) collect and geochemically fingerprint samples from these natural occurrences; (3) geochemically fingerprint (with biomarkers) coastal tar residues and potential tar sources in this region, both onshore and offshore; and (4) establish 
chemical correlations between offshore active seeps and coastal residues, thus linking seep sources to oil residues. The results of this study can be found in Hostettler and others (2004), Peters and others (2008), and Lorenson and others (2009, 2011).

Biomarkers are complex organic compounds that are in petroleum, rocks, and sediment, and they show little change in structure from their parent organic molecules in living organisms (Peters and others, 2005). For this work, 667 tarballs, tar residues, seeps, bitumen in rock, and production oils, mainly from coastal locations, were fingerprinted using biomarkers; the samples are listed in their entirety in Lorenson and others (2009, 2011), along with accompanying metadata and chemicalfingerprint data.

Each onshore sample was separated from rocks or sand with a clean knife and placed in a precleaned glass jar for transport to the laboratory. Samples of tar or oil found floating in seawater were placed in a precleaned glass jar, and any seawater was poured off before analysis. Samples of production oils were taken directly from sampling ports at the production site. All samples were dissolved in dichloromethane (DCM), then filtered through glass wool to remove particulates and air-dried to remove DCM. After filtration and removal of DCM, a portion of the clean extract was removed to determine bulk stable-carbon-isotope composition by an isotope-ratio mass spectrometer. A second portion of the extract was then loaded onto a liquid chromatography column for compound class separation. Two separate fractions - the saturate and the aromatic - were collected for analysis by gas chromatography/mass spectrometry. Chromatograms of a typical coastal tar residue, including a total ion chromatogram and selected ion-monitoring mass chromatograms of terpanes (mass/charge [m/z] 191) and steranes (m/z 217), are shown in figure 9-1.

Using multivariate statistical techniques (Peters and others, 2008), the oil was divided into three "tribes" of ${ }^{13}$ C-rich oils, inferred to originate from thermally mature equivalents of three types of strata from the Monterey Formation: (1) clayey-siliceous shale, (2) carbonaceous marl, and (3) calcareoussiliceous carbonate. These three tribes have been further subdivided into 13 oil "families," and seven of these families are present in the Offshore of Coal Oil Point map area. Of these seven, Family 211 is most frequently identified, both onshore as tarballs and offshore as seep sources. Samples identified as Family 0 cannot be classified in the model, owing to severe biodegradation; however, they can be identified as natural seepage derived from the Monterey Formation.

Tribe 1, which originated from clay-rich shale deposited under suboxic conditions with substantial higher-plant input, has a high Ts/Tm $\left(\mathrm{C}_{27} 18 \alpha(\mathrm{H})\right.$-trisnorhopane/ $\mathrm{C}_{27} 17 \alpha(\mathrm{H})$-trisnorhopane) ratio, consistent with a clay-rich shale source rock (Moldowan and others, 1986), as well as a high oleanane/hopane ratio. Oleanane is a biomarker from terrigenous higher plants (angiosperms) in source rocks and related crude oils of Cretaceous or younger age (Moldowan and others, 1994). Low 28,30-bisnorhopane/hopane and $\mathrm{C}_{35} \mathrm{~S} / \mathrm{C}_{34} \mathrm{~S}$ hopane ratios for Tribe 1 (compared to those of Tribe 3) are consistent with suboxic source rocks (Katz and Elrod, 1983; Peters and Moldowan, 1991). The same parameters for Tribe 3 indicate an anoxic, clay-poor, carbonate source rock dominated by pelagic organic matter with little or no higher-plant input. Trace-element, sediment-fabric, and benthic-biofacies data support low oxygen concentrations in bottom water during deposition of the Monterey Formation (Isaacs, 2001).

Except for high 28,30-bisnorhopane (BNH; also called 28,30-dinorhopane), the biomarker chemistry parameters for Tribe 2 indicate an intermediate composition between Tribes 1 and 3: that is, suboxic to anoxic, marine-marl source rock that has hemipelagic (mixed marine and terrigenous) organic-matter input. BNH originates from sulfur-oxidizing bacteria (similar to Beggiatoa spp.), although the exact precursor organisms remain unidentified (Schoell and others, 1992). Beggiatoa spp. organisms grow at the dysoxic interface between oxic and anoxic zones, commonly at the sedimentwater interface, and they were identified as the mat-forming bacteria that contribute to laminated 
sediments in the Santa Barbara Basin (Soutar and Crill, 1977; Williams, 1984), a possible modern analog for depositional conditions of the Monterey Formation (Pisciotto and Garrison, 1981).

The map on sheet 11 also shows known onshore and offshore oil and gas fields, as well as gasseepage areas as mapped by others prior to and during this study (California Division of Oil, Gas, and Geothermal Resources, 2001). Also shown is the extent of gas seepage as mapped by Hornafius and others (1999); in addition, figure 1 on sheet 11 shows a resurvey of normalized sonar return of gasemission intensity of seep-bubble plumes, as measured in 2005 by Leifer and others (2010). Sample numbers displayed on the map correspond to the study by Lorenson and others $(2009,2011)$. The shaded-relief map shows some of the seafloor structure underlying the area. Remotely operated vehicle (ROV) surveys were conducted on three occasions. The dive locations were chosen by the analysis of previous surveys of seafloor morphology sea-surface hydrocarbon-seep expression, as well as of the concentration of dissolved methane in seawater. Once located, the asphalt mounds were sampled by the ROV manipulator arm, and the samples were returned to the surface for future analyses in the laboratory. Examples of the range of hydrocarbon emissions and tarball accumulations are shown in the photographs in figures 3 through 13 on sheet 11. 


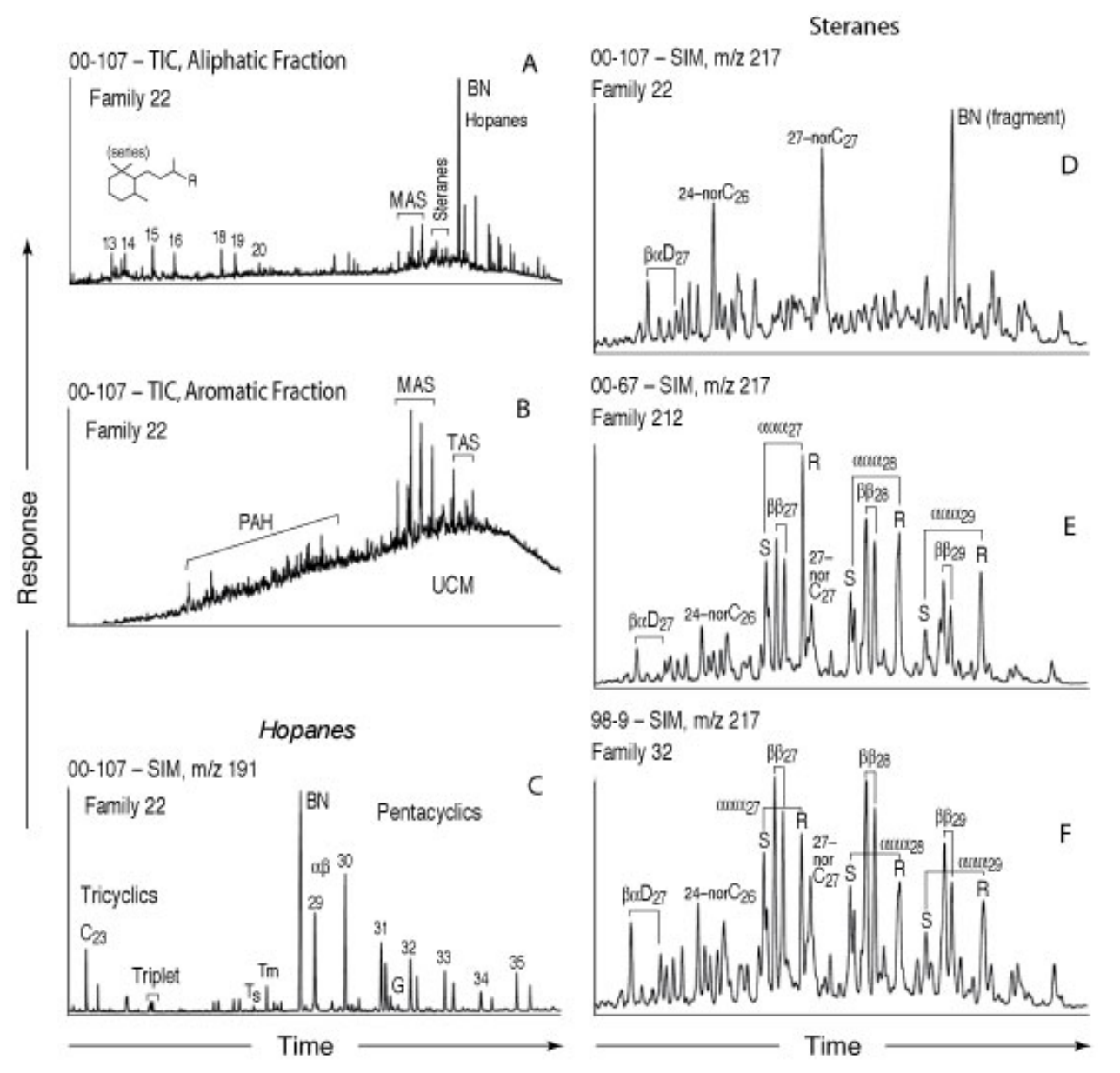

Figure 9-1. Chromatograms of selected tarball samples (from Lorenson and others, 2009). A, Total ion chromatogram of aliphatic fraction, sample no. 00-107, Family 22. B, Total ion chromatogram of aromatic fraction, sample no. 00-107, Family 22. C, Selected ion monitoring chromatogram of $\mathrm{m} / \mathrm{z} 191$, hopanes, sample no. 00-107, Family 22. C, Selected ion monitoring chromatogram of $\mathrm{m} / \mathrm{z}$ 191, hopanes, sample no. 00-107, Family 22. D, Selected ion monitoring chromatogram of $\mathrm{m} / \mathrm{z} 217$, steranes, sample no. 00-107, Family 22. $E$, Selected ion monitoring chromatogram of $\mathrm{m} / \mathrm{z} 217$, steranes, sample no. 00-67, Family 212. $F$, Selected ion monitoring chromatogram of $\mathrm{m} / \mathrm{z} 217$, steranes, sample no. 98-9, Family 32. Abbreviations and definitions: SIM, selected ion monitoring chromatogram; TIC, total ion chromatogram; MAS, monoaromatic steranes; steranes, $\mathrm{C}_{26}, \mathrm{C}_{27}, \mathrm{C}_{28}, \mathrm{C}_{29}$ regular steranes; hopanes, $\mathrm{C}_{27}, \mathrm{C}_{28}, \mathrm{C}_{29}, \mathrm{C}_{30}, \mathrm{C}_{31}, \mathrm{C}_{32}, \mathrm{C}_{33}, \mathrm{C}_{34}, \mathrm{C}_{35}$ regular hopanes; $\mathrm{BN}$, 28,30-bisonorhopane; UCM, unresolved complex mixture; 23T, $\mathrm{C}_{23}$-tricyclic terpane; $\mathrm{C}_{24}, \mathrm{C}_{25}, \mathrm{C}_{27}, \mathrm{C}_{38}$, tricyclic terpanes; T, Triplet [ $\mathrm{C}_{26}$-tricyclic terpane (S?) + $\mathrm{C}_{26}$-tricyclic terpane (R?)/ $\mathrm{C}_{24}$-tetracyclic terpane]; $\mathrm{Ts}, \mathrm{C}_{27}$ 18a(H)-trisnorhopane; Tm, $\mathrm{C}_{27}$ 17a(H)-trisnorhopane; BN, bisnorhopane; aß29, aß30, aß31, aß32, aß33, aß34, aß35 (S \& R epimers), aß-hopanes with carbon numbers; O, oleanane; G, gammacerane; $S, R=$ epimers of aaa 27 , aaa 28 , aaa29, $\beta \beta 27, \beta \beta 28, \beta \beta 29$ steranes. 


\title{
Chapter 10. Predictive Distribution of Benthic Macro-Invertebrates for the Offshore of Coal Oil Point Map Area and the Santa Barbara Channel Region (Sheet 12)
}

\author{
By Lisa M. Krigsman, Mary M. Yoklavich, Nadine E. Golden, and Guy R. Cochrane
}

Modeling the distribution of ecologically and economically important species provides managers and conservation planners with information on a broad spatial scale that is useful to coastal management, ocean energy, marine protected areas, and marine spatial planning. Sheet 12 displays predictive models of occurrence for common benthic macro-invertebrate taxa and maps the probability of occurrence of these taxa in the Santa Barbara Channel region (Krigsman and others, 2012). These models are based on real-time biological observations of all macro-organisms made during ground-truth surveys (sheet 6) conducted in 2008 and 2009; the observations were made during a 10-second interval every minute along video transects, which were approximately $1 \mathrm{~km}$ in length (see sheet 6 ; see also, chapter 5 of this pamphlet). These transects produced a total of 923 observations from Refugio Beach $\left(34.5^{\circ}\right.$ N., $120.1^{\circ}$ W.) to Hueneme Canyon (34.1 ${ }^{\circ}$ N., $119.2^{\circ}$ W.).

Five invertebrate taxa—cup corals, hydroids, short sea pens, tall sea pens, and brittle stars (which protrude out of the sediment)—were selected for modeling purposes because of their frequent occurrence in the Santa Barbara Channel; all are structure-forming components of valuable habitat for groundfish species (Krigsman and others, 2012). Presence-absence data for the selected invertebrates were fit to multiple generalized linear models using a combination of three covariates-geographic location, seafloor character (sheet 5), and shaded-relief bathymetry (sheet 2) —as well as relevant interaction terms. Geographic locations for the five observed invertebrates were derived from analysis of the video data from an area along the mainland coast of the Santa Barbara Channel; the Offshore of Carpinteria map area was excluded because of insufficient data. Three statistically different locations were identified on the basis of a community-structure analysis: (1) the Hueneme Canyon and Vicinity and Offshore of Ventura map areas; (2) the Offshore of Santa Barbara and Offshore of Coal Oil Point map areas; and (3) the Offshore of Refugio Beach map area. Best-fit models were selected for each invertebrate on the basis of Akaike's Information Criterion (AIC) (Akaike, 1974), a best-fit model being defined as the one that has the fewest parameters within two AIC points of the minimum score.

The seafloor in the Offshore of Coal Oil Point map area has siliceous bedrock reefs made up of Class II (mixed habitat) and Class III (rugose rock) that are surrounded by large areas of Class I (unconsolidated sediment) (see sheet 5; see also, chapter 4 in this pamphlet). Note that predictions for this map area are constrained to depths between 5 and $150 \mathrm{~m}$ owing to limitations of the camera sled, so that no predictions are available in the map area for outside of California's State Waters.

Cup corals (Map D on sheet 11), a benthic cnidarian typically found on mixed and rocky habitats, have a moderate to high (50-80 percent) probability of occurrence in areas where suitable habitat is present. Hydroids (Map C on sheet 11), another benthic cnidarian found on habitat similar to cup corals, have a low probability of occurrence on the nearshore reefs, but, as depth increases, so does the probability of occurrence in areas of mixed sediment and rugose rock.

Sea pens, also members of the phylum Cnidaria, are divided into two groups— short and tall—on the basis of their size. Sea pens less than $60 \mathrm{~cm}$ in height are identified as short sea pens (Stylatula spp. and Virgularia spp.); those taller than $60 \mathrm{~cm}$ are identified as tall sea pens (Halipteris spp.) (Maps B and A, respectively, on sheet 11). Sea pens typically are associated with unconsolidated and mixed sediment because their rootlike base anchors them to the seafloor. Short sea pens have the highest probability of occurrence on unconsolidated sediment at depths of between 30 and $60 \mathrm{~m}$, whereas tall sea pens have the highest probability of occurrence at depths greater than $60 \mathrm{~m}$. 
Brittle stars (Map E on sheet 11) can occur in such high densities in the sediment that they create a thick carpet on the seafloor. Like sea pens, they typically are associated with unconsolidated and mixed sediment into which they burrow; however, they also are found in cracks and crevices within rugose rock. In the offshore of Coal Oil Point map area, brittle stars have a low probability of occurrence (about 35 percent) in unconsolidated sediment at depths between 30 and $60 \mathrm{~m}$. At depths less than $30 \mathrm{~m}$ and also greater than $60 \mathrm{~m}$, the probability of occurrence is very low.

These predictive maps are based on data available from the California Seafloor Mapping Program (location, habitat type, and bathymetry). Other factors such as ocean currents (Cudaback and others, 2005), water temperature (Bingham and others, 1997), larval distribution (Grantham and others, 2003), and recruitment and mortality (Keough and Downes, 1982) also can significantly influence the distribution and abundance of these benthic macro-invertebrate taxa. 


\section{Acknowledgments}

This publication was funded by the California Ocean Protection Council and the U.S. Geological Survey (USGS) Coastal and Marine Geology Program. Gerald Hatcher (USGS) designed the automatic camera system that photographed many of the features on sheet 11, and Peter Dartnell (USGS) assisted with seafloor observations. Ralph Haugerud and Curt Storlazzi (both USGS) provided constructive peer reviews. We are very grateful to USGS editor Taryn Lindquist for helping us develop the templates and formats for this series of publications and for invaluable editorial review and suggestions. 


\section{References Cited}

Aikake, H., 1974, A new look at the statistical model identification: Institute of Electrical and

Electronics Engineers Transactions on Automatic Control, v. 19, p. 716-723.

Allen, A.A., Schleuter, R.S., and Mikolaj, P.G., 1970, Natural oil seepage at Coal Oil Point, Santa

Barbara, California: Science, v. 170, p. 974-977.

Anderson, T.J., Cochrane, G.R., Roberts, D.A., Chezar, H., and Hatcher, G., 2007, A rapid method to characterize seabed habitats and associated macro-organisms, in Todd, B.J., and Greene, H.G., eds., Mapping the seafloor for habitat characterization: Geological Association of Canada Special Paper 47, p. 71-79.

Barnum, H.P., 1998, Redevelopment of the western portion of the Rincon offshore oil field, Ventura, California, in Kunitomi, D.S., Hopps, T.E., and Galloway, J.M., eds., Structure and petroleum geology, Santa Barbara Channel, California: American Association of Petroleum Geologists, Pacific Section, and Coast Geological Society, Miscellaneous Publication 46, p. 201-215.

Bartlett, W.L., 1998, Ellwood oil field, Santa Barbara County, California, in Kunitomi, D.S., Hopps, T.E., and Galloway, J.M., eds., Structure and petroleum geology, Santa Barbara Channel, California: American Association of Petroleum Geologists, Pacific Section, and Coast Geological Society, Miscellaneous Publication 46, p. 217-237.

Bingham, B.L., Bacigalupi, M., and Johnson, L.G., 1997, Temperature adaptations of embryos from intertidal and subtidal sand dollars (Dendraster excentricus, Eschscholtz): Northwest Science, v. 71(2), p. 108-114.

Brickey, M.R., 1998, Oil and gas fields of the Santa Barbara Channel area, in Kunitomi, D.S., Hopps, T.E., and Galloway, J.M., eds., Structure and petroleum geology, Santa Barbara Channel, California: American Association of Petroleum Geologists, Pacific Section, and Coast Geological Society, Miscellaneous Publication 46, preface (2 p.).

Briggs, J.C., 1974, Marine zoogeography: New York, McGraw-Hill, 480 p.

Caldwell, R.J., Taylor, L.A., Eakins, B.W., Carignan, K.S., Grothe, P.R., Lim, E., and Friday, D.Z., 2010, Digital elevation models of Santa Monica, California_-Procedures, data sources and analysis: NOAA Technical Memorandum NESDIS NGDC-46, NOAA National Geophysical Data Center, available at http://www.ngdc.noaa.gov/dem/squareCellGrid/download/663.

California Department of Fish and Game, 2008, California Marine Life Protection Act master plan for marine protected areas-Revised draft: California Department of Fish and Game, available at http://www.dfg.ca.gov/mlpa/masterplan.asp.

California Division of Oil, Gas, and Geothermal Resources, 2001, Oil, gas, and geothermal fields in California: California Division of Oil, Gas, and Geothermal Resources, scale 1:1,500,000, available at ftp://ftp.consrv.ca.gov/pub/oil/maps/Map_S-1.pdf.

Carignan, K.S., Taylor, L.A., Eakins, B.W., Warnken, R.R., Lim, E., and Medley, P.R., 2009, Digital elevation model of Santa Barbara, California-Procedures, data sources, and analysis: NOAA Technical Memorandum NESDIS NGDC-29, NOAA National Geophysical Data Center, available at http://www.ngdc.noaa.gov/dem/squareCellGrid/download/603.

Clark, J.F., Washburn, L., Hornafius, J.S., and Luyendyk, B.P., 2000, Dissolved hydrocarbon flux from natural marine seeps to the Southern California Bight: Journal of Geophysical Research, v. 105, p. $11,509-11,522$.

Cochrane, G.R., 2008, Video-supervised classification of sonar data for mapping seafloor habitat, in Reynolds, J.R., and Greene, H.G., eds., Marine habitat mapping technology for Alaska: Fairbanks, University of Alaska, Alaska Sea Grant College Program, p. 185-194, available at http://doc.nprb. org/web/research/research\%20pubs/615_habitat_mapping_workshop/Individual\%20Chapters\%20 High-Res/Ch13\%20Cochrane.pdf 
Cochrane, G.R., and Lafferty, K.D., 2002, Use of acoustic classification of sidescan sonar data for mapping benthic habitat in the Northern Channel Islands, California: Continental Shelf Research, v. 22, p. 683-690.

Cochrane, G.R., Conrad, J.E., Reid, J.A., Fangman, S., and Golden, N., 2005, Nearshore benthic habitat GIS for the Channel Islands National Marine Sanctuary and southern California state fisheries reserves, volume II: U.S. Geological Survey Open-File Report 2005-1170, available at http://pubs. usgs.gov/of/2005/1170/.

Cochrane, G.R., Nasby, N.M., Reid, J.A., Waltenberger, B., and Lee, K.M., 2003, Nearshore benthic habitat GIS for the Channel Islands National Marine Sanctuary and southern California state fisheries reserves, volume 1: U.S. Geological Survey Open-File Report 2003-85, available at http://pubs.usgs. gov/of/2003/0085/.

Cudaback, C.N., Washburn, L., and Dever, E., 2005, Subtidal inner-shelf circulation near Point Conception, California: Journal of Geophysical Research, v. 110, C10007, doi:10.1029/ 2004JC002608.

Dartnell, P, Conrad, J.E., Stanley, R.G., and Cochrane, G.R., 2010, Onshore and offshore geologic map of the Coal Oil Point area, southern California: U.S. Geological Survey Scientific Investigations Map 3124, scale 1:24,000, pamphlet 18 p., available at http://pubs.usgs.gov/sim/3124/.

Del Sontro, T.S., Leifer, I., Luyendyk, B.P., and Broitman, B.R., 2007, Beach tar accumulation, transport mechanisms, and sources of variability at Coal Oil Point, California: Marine Pollution Bulletin, v. 54, p. 1,461-1,471, doi:10.1016/j.marpolbul.2007.04.022.

Dibblee, T.W., Jr., 1981, Geologic map of the Tajiguas quadrangle, California: U.S. Geological Survey Open-File Report 81-371, 1:24,000.

Dibblee, T.W., Jr., 1987a, Geologic map of the Dos Pueblos quadrangle, Santa Barbara County, California: Santa Barbara, Calif., Dibblee Geological Foundation Map DF-09, scale 1:24,000.

Dibblee, T.W., Jr., 1987b, Geologic map of the Goleta quadrangle, Santa Barbara County, California: Santa Barbara, Calif., Dibblee Geological Foundation Map DF-07, scale 1:24,000.

Draut, A.E., Hart, P.E., Lorenson, T.D., Ryan, H.F., Wong, F.L., Sliter, R.W., and Conrad, J.E., 2009, Late Pleistocene to Holocene sedimentation and hydrocarbon seeps on the continental shelf of a steep, tectonically active margin, southern California, USA: Marine Geophysical Research, p. 193-206, doi: 10.1007/s11001-009-9076-y.

Eichhubl, P., Greene, H.G., and Maher, N., 2002, Physiography of an active transpressive margin basin-High-resolution bathymetry of the Santa Barbara basin, southern California continental borderland: Marine Geology, v. 184, p. 95-120.

Fader, G.B.J., 1997, Effects of shallow gas on seismic-reflection profiles, in Davies, T.A., Bell, T., Cooper, A.K., Josenhaus, H., Polyak, L., Solheim, A., Stoker, M.S., and Stravers, J.A., eds., Glaciated continental margins-An atlas of acoustic images: London, Chapman \& Hall, p. 29-30.

Fairbanks, R.G., 1989, A 17,000-year glacio-eustatic sea level record-Influence of glacial melting rates on the Younger Dryas event and deep-ocean circulation: Science, v. 342, p. 637-642.

Fischer, P.J., and Stevenson, A.J., 1973, Natural hydrocarbon seeps, Santa Barbara basin, California, in Fischer, P.J., ed., Santa Barbara Channel area revisited: American Association of Petroleum Geologists, Field Trip Guidebook 3, p. 17-28.

Fisher, M.A., Normark, W.R., Greene, H.G., Lee, H.J., and Sliter, R.W., 2005, Geology and tsunamigenic potential of submarine landslides in Santa Barbara Channel, southern California: Marine Geology, v. 224, p. 1-22.

Fisher, M.A., Sorlien, C.C., and Sliter, R.W., 2009, Potential earthquake faults offshore southern California from the eastern Santa Barbara channel to Dana Point, in Lee, H.J., and Normark, W.R., eds., Earth science in the urban ocean-The Southern California Continental Borderland: Geological Society of America Special Paper 454, p. 271-290. 
Fleming, K., Johnston, P., Zwartz, D., Yokoyama, Y., Lambeck, K., and Chappell, J., 1998, Refining the eustatic sea-level curve since the Last Glacial Maximum using far- and intermediate-field sites: Earth and Planetary Science Letters, v. 163, p. 327-342, doi:10.1016/S0012-821X(98)00198-8.

Galloway, J.M., 1997, Santa Barbara-Ventura basin province, in Dunkel, C.A., and Piper, K.A. eds., 1995 National assessment of United States oil and gas resources assessment of the pacific outer continental shelf region: U.S. Department of the Interior Minerals Management Service Pacific OCS Region Office of Resource Evaluation, OCS report MMS 92-0019, p. 96-115.

Galloway, J.M., 1998, Chronology of petroleum exploration and development in the Santa Barbara channel area, offshore southern California, in Kunitomi, D.S., Hopps, T.E., and Galloway, J.M., eds., Structure and petroleum geology, Santa Barbara Channel, California: American Association of Petroleum Geologists, Pacific Section, and Coast Geological Society, Miscellaneous Publication 46, p. $1-12,1$ sheet.

Gotshall, D.W., 2005, Guide to marine invertebrates-Alaska to Baja (2d ed.): Monterey, Calif., Sea Challengers, $117 \mathrm{p}$.

Grantham, B.A., Eckert, G.L., and Shanks, A.L., 2003, Dispersal potential of marine invertebrates in diverse habitats: Ecological Applications, v. 13(1), supplement p. S108-S116.

Greene, H.G., Bizzarro, J.J., O’Connell, V.M., and Brylinsky, C.K., 2007, Construction of digital potential marine benthic habitat maps using a coded classification scheme and its application, in Todd, B.J., and Greene, H.G., eds., Mapping the seafloor for habitat characterization: Geological Association of Canada Special Paper 47, p. 141-155.

Greene, H.G., Bizzarro, J.J., Tilden, J.E., Lopez, H.L., and Erdey, M.D., 2005, The benefits and pitfalls of geographic information systems in marine benthic habitat mapping, in Wright, D.J., and Scholz, A.J., eds., Place matters: Portland, Oregon State University Press, p. 34-46.

Greene, H.G., Murai, L.Y., Watts, P., Maher, N.A., Fisher, M.A., and Eichhubl, P., 2006, Submarine landslides in the Santa Barbara channel as potential tsunami sources: Natural Hazards and Earth System Sciences, v. 6, p. 63-88.

Greene, H.G., Yoklavich, M.M., Starr, R.M., O’Connell, V.M., Wakefield, W.W., Sullivan, D.E., McRea, J.E., and Cailliet, G.M., 1999, A classification scheme for deep seafloor habitats: Oceanologica Acta, v. 22, p. 663-678.

Griggs, G., Patsch, K., and Savoy, L., 2005, Living with the changing California coast: Berkeley, University of California Press, 540 p.

Gurrola, L.D., Keller, E.A., Chen, J.H., Owen, L.A., and Spencer, J.Q., 2014, Tectonic geomorphology of marine terraces-Santa Barbara fold belt, California: Geological Society of America Bulletin, v. 126, p. 219-233.

Hapke, C.J., and Reid, D.R., 2007, National assessment of shoreline change, part 4-Historical coastal cliff retreat along the California Coast: U.S. Geological Survey Open-File Report 2007-1133, 51 p., available at http://pubs.usgs.gov/of/2007/1133/.

Hapke, C.J., Reid, D., Richmond, B.B., Ruggiero, P., and List, J., 2006, National assessment of shoreline change, part 3-Historical shoreline change and associated coastal land loss along sandy shorelines of the California coast: U.S. Geological Survey Open-File Report 2006-1219, 72 p., available at http://pubs.usgs.gov/of/2006/1219/.

Heck, R.G., 1998, Santa Barbara Channel regional formline map, top Monterey Formation, in Kunitomi, D.S., Hopps, T.E., and Galloway, J.M., eds., Structure and petroleum geology, Santa Barbara Channel, California: American Association of Petroleum Geologists, Pacific Section, and Coast Geological Society, Miscellaneous Publication 46, 1 plate.

Hornafius, J.S., Luyendyk, B.P., Terres, R.R., and Kamerling, M.J., 1986, Timing and extent of Neogene rotation in the western Transverse Ranges, California: Geological Society of America Bulletin, v. 97, p. 1,476-1,487. 
Hornafius, J.S., Quigley, D.C., and Luyendyk, B.P., 1999, The world’s most spectacular marine hydrocarbon seeps (Coal Oil Point, Santa Barbara Channel, California)—Quantification of emissions: Journal of Geophysical Research - Oceans, v. 104, p. 20,703-20,711.

Hostettler, F.D., Rosenbauer, R.J., Lorenson, T.D., and Dougherty, J.A., 2004, Geochemical characterization of tarballs on beaches along the California coast, part I-Shallow seepage impacting the Santa Barbara Channel Islands, Santa Cruz, Santa Rosa and San Miguel: Organic Geochemistry, v. 35, p. 725-746.

Hovland, M., and Judd, A.G., 1988, Seabed pockmark and seepages: London, Graham and Trotman, Inc., 293 p.

Isaacs, C.M., 2001, Depositional framework of the Monterey Formation, California, in Isaacs, C.M., and Rullkötter, J., eds., The Monterey Formation, from rocks to molecules: New York, Columbia University Press, p. 1-30.

Jennings, C.W., and Bryant, W.A., 2010, Fault activity map of California: California Geological Survey Geologic Data Map no. 6, scale 1:750,000.

Katz, B.J., and Elrod, L.W., 1983, Organic geochemistry of DSDP site 467, offshore California, middle Miocene to lower Pliocene strata: Geochimica et Cosmochimica Acta, v. 47, p. 389-396.

Keller, E.A., and Gurrola, L.D., 2000, Final Report, July, 2000—Earthquake hazard for the Santa Barbara fold belt, California: NEHRP Award \#99HQGR0081, SCEC Award \#572726, 78 p., accessed April 2011 at http.www.geol.ucsb.edu/-keller/sbeqh.pdf.

Keough, M.J., and Downes, B.J., 1982, Recruitment of marine invertebrates-The role of active larval choices and early mortality: Oecologia, v. 54, 348-352.

Kern, J.P., 1977, Origin and history of upper Pleistocene marine terraces, San Diego, California: Geological Society of America Bulletin, v. 88, p. 1,553-1,566.

Krigsman, L.M., Yoklavich, M.M., Dick, E.J., and Cochrane, G.R., 2012, Models and maps_-Predicting the distribution of corals and other benthic macro-invertebrates in shelf habitats: Ecosphere, v. 3(1), article 3, 16 p., doi:http://dx.doi.org/10.1890/ES11-00295.1.

Kunitomi, D.S., Hopps, T.E., and Galloway, J.M., eds., 1998, Structure and petroleum geology, Santa Barbara Channel, California: American Association of Petroleum Geologists, Pacific Section, and Coast Geological Society, Miscellaneous Publication 46, 328 p.

Kvitek, R., 2007, California State University, Monterey Bay, Seafloor Mapping Lab Data Library: California State University, Monterey Bay, Seafloor Mapping Lab database, accessed May 12, 2011, at http://seafloor.csumb.edu/SFMLwebDATA.htm.

Kvitek, R., Bretz, C., Cochrane, G.R., and Greene, H.G., 2006, Final report, Statewide Marine Mapping Planning Workshop, December 12-13, 2005, Seaside, Calif.: California State University, Monterey Bay, 108 p., accessed April 5, 2011, at http://euclase.csumb.edu/DATA_DOWNLOAD/Strategic MapgWrkshp05/MappingWorkshop12_1213/Final_Report/CA\%20Habitat\%20Mapping\%20Rpt.pdf.

Lambeck, K., and Chappell, J., 2001, Sea level change through the last glacial cycle: Science, v. 292, p. 679-686, doi: 10.1126/science.1059549.

Landes, K.K., 1973, Mother nature as an oil polluter: American Association of Petroleum Geologists Bulletin, v. 57, p. 637-641.

Larson, K.M., and Webb, F.H., 1992, Deformation in the Santa Barbara Channel from GPS measurements 1987-1991: Geophysical News Letters, v. 19, p. 1,491-1,494.

Lee, H.J., and Normark, W.R., eds., 2009, Earth science in the urban ocean-The Southern California Continental Borderland: Geological Society of America Special Paper 454, 481 p.

Lee, H.J., Normark, W.R., Fisher, M.A., Greene, H.G., Edwards, B.D., and Locat, J., 2004, Timing and extent of submarine landslides in southern California: Houston, Tex., Offshore Technology Conference, May 3, 2004, Proceedings, Paper 16744, 11 p. 
Lee, H.J., Greene, H.G., Edwards, B.D., Fisher, M.A., and Normark, W.R., 2009, Submarine landslides in the southern California borderland, in Lee, H.J., and Normark, W.R., eds., Earth science in the urban ocean-The Southern California Continental Borderland: Geological Society of America Special Paper 454, p. 251-269.

Lee, W.H.K., and Vedder, J.G., 1973, Recent earthquake activity in the Santa Barbara Channel region: Bulletin of the Seismological Society of America, v. 63, p. 1,757-1,773.

Leifer, I., Kamerling, M., Luyendyk, B.P., and Wilson, D.S., 2010, Geologic control of natural marine hydrocarbon seep emissions, Coal Oil Point seep field, California: Geo-Marine Letters, v. 30, p. 331-338, doi:10.1007/s00367-010-0188-9.

Lorenson, T.D., Hostettler, F.D., Rosenbauer, R.J., Peters, K.E., Kvenvolden, K.A., Dougherty, J.A., Gutmacher, C.E., Wong, F.L., and Normark, W.R., 2009, Natural offshore seepage and related tarball accumulation on the California coastline, Santa Barbara Channel and the southern Santa Maria Basin-Source identification and inventory: U.S. Geological Survey Open-File Report 2009-1225 [also released as Minerals Management Service Report 2009-030], 116 p., available at http://pubs. usgs.gov/of/2009/1225/.

Lorenson, T.D., Leifer, I., Wong, F.L., Rosenbauer, R.J., Campbell, P.L., Lam, A., Hostettler, F.D., Greinert, J., Finlayson, D.P., Bradley, E.S., and Luyendyk, B.P., 2011, Biomarker chemistry and flux quantification methods for natural petroleum seeps and produced oils, offshore southern California: U.S. Geological Survey Scientific Investigations Report 2011-5210 [also released as Bureau of Ocean Energy Management OCS Study BOEM 2011-016], 45 p., available at http://pubs.usgs.gov/sir/2011/ $5210 /$.

Luyendyk, B.P., Kamerling, M.J., and Terres, R.R., 1980, Geometric model for Neogene crustal rotations in southern California: Geological Society of America Bulletin, v. 91, p. 211-217.

Madden, C.J., Goodin, K.L., Allee, R., Finkbeiner, M., and Bamford, D.E., 2008, Draft Coastal and Marine Ecological Classification Standard: National Oceanic and Atmospheric Administration (NOAA) and NatureServe, v. III, 77 p.

Metcalf, J.G., 1994, Morphology, chronology, and deformation of Pleistocene marine terraces, southwestern Santa Barbara County, California: Santa Barbara, University of California, M.S. thesis, $168 \mathrm{p}$.

Minor, S.A., Kellogg, K.S., Stanley, R.G., Gurrola, L.D., Keller, E.A., and Brandt, T.R., 2009, Geologic map of the Santa Barbara coastal plain area, Santa Barbara County, California: U.S. Geological Survey Scientific Investigations Map 3001, scale 1:25,000, 1 sheet, pamphlet 38 p., available at http://pubs.usgs.gov/sim/3001/.

Mitchum, R.M., Jr., Vail, P.R., and Sangree, J.B., 1977, Seismic stratigraphy and global changes of sea level, part 6-Stratigraphic interpretation of seismic reflection patterns in depositional sequences, in Payton, C.E., ed., Seismic stratigraphy_Applications to hydrocarbon exploration: Tulsa, Okla., American Association of Petroleum Geologists, p. 117-133.

Moldowan, J.M., Dahl, J., Huizinga, B.J., Fago, F.J., Hickey, L.J., Peakman, T.M., and Taylor, D.W., 1994, The molecular fossil record of oleanane and its relation to angiosperms: Science, v. 265, p. 768-771.

Moldowan, J.M., Sundararaman, P., and Schoell, M., 1986, Sensitivity of biomarker properties to depositional environment and/or source input in the Lower Toarcian of S.W. Germany: Organic Geochemistry, v. 10, p. 915-926.

Monterey Bay Aquarium Research Institute, 2001, Santa Barbara multibeam survey: Monterey Bay Aquarium Research Institute Digital Data Series 4, 2 CD-ROMs.

Muhs, D.R., Rockwell, T.K., and Kennedy, G.L., 1992, Late Quaternary uplift rates of marine terraces on the Pacific Coast of North America, southern Oregon to Baja California Sur: Quaternary International, v. 15/16, p. 121-133. 
Muhs, D.R., Wehmiller, J.F., Simmons, K.R., and York, L.L., 2004, Quaternary sea-level history of the United States, in Gillespie, A.R., Porter, S.C., and Atwater, B.F., eds.. Developments in Quaternary Science: Amsterdam, Elsevier, p. 147-183.

National Oceanic and Atmospheric Administration, 2011, Coastal ifSAR: Digital Coast, NOAA Coastal Services Center database, available at http://www.csc.noaa.gov/digitalcoast/.

Nicholson, C., Sorlien, C., Atwater, T., Crowell, J.C., and Luyendyk, B.P., 1994, Microplate capture, rotation of the western Transverse Ranges, and initiation of the San Andreas transform as a low-angle fault system: Geology, v. 22, p. 491-495.

Normark, W.R., Piper, D.J.W., Romans, B.W., Covault, J.A., Dartnell, P., and Sliter, R.W., 2009, Submarine canyon and fan systems of the California Continental Borderland, in Lee, H.J., and Normark, W.R., eds., Earth science in the urban ocean-The Southern California Continental Borderland: Geological Society of America Special Paper 454, p. 141-168.

O’Reilly, W.C., and Guza, R.T., 1993, A comparison of spectral wave models in the Southern California Bight: Coastal Engineering, v. 19, p. 263-282, doi: 10.1016/0378-3839(93)90032-4.

Peltier, W.R., 2005, On the hemispheric origins of meltwater pulse 1a: Quaternary Science Reviews, v. 24, p. 1,655-1,671.

Peltier, W.R., and Fairbanks, R.G., 2006, Global glacial ice volume and Last Glacial Maximum duration from an extended Barbados sea level record: Quaternary Science Reviews, v. 25, p. 3,322-3,337.

Peters, K.E., and Moldowan, J.M., 1991, Effects of source, thermal maturity, and biodegradation on the distribution and isomerization of homohopanes in petroleum: Organic Geochemistry, v. 17, p. 47-61.

Peters, K.E., Hostettler, F.D., Lorenson, T.D., and Rosenbauer, R.R., 2008, Families of Miocene Monterey crude oil, seep, and tarball samples, coastal California: American Association of Petroleum Geology Bulletin, v. 92, no. 9, p. 1,131-1,152.

Peters, K.E., Walters, C.C., and Moldowan, J.M., 2005, The biomarker guide: Cambridge, Cambridge University Press, 1,155 p.

Petersen, M.D., Frankel, A.D., Harmsen, S.C., Mueller, C.S., Haller, K.M., Wheeler, R.L., Wesson, R.L., Zeng, Y., Boyd, O.S., Perkins, D.M., Luco, N., Field, E.H., Wills, C.J., and Rukstales, K.S., 2008, Documentation for the 2008 update of the United States National Seismic Hazard Maps: U.S. Geological Survey Open-File Report 2008-1128, 61 p., accessed April 5, 2011, at http://pubs. usgs.gov/of/2008/1128/.

Pisciotto, K.A., and Garrison, R.E., 1981, Lithofacies and depositional environments of the Monterey Formation, California, in Garrison, R.E., and Douglas, R.G., eds., The Monterey Formation and related siliceous rocks of California: Society of Economic Paleontologists and Mineralogists, Pacific Section, Book 15, p. 97-122.

Quigley, D.C., Hornafius, J.S., Luyendyk, B.P., Francis, R.D., Clark, J., and Washburn, L., 1999, Decrease in natural marine hydrocarbon seepage near Coal Oil Point, California, associated with offshore oil production: Geology, v. 27, p. 1,047-1,050.

Redin, T., 2005, Santa Barbara Channel structure and correlation sections-Correlation Section no. 36, N-S structure and correlation section, western Santa Ynez Mountains across the Santa Barbara Channel to Santa Rosa Island: American Association of Petroleum Geologists, Pacific Section, Publication CS 36, 1 sheet.

Redin, T., Kamerling, M., and Forman, J., 2005, Santa Barbara Channel structure and correlation sections-Correlation Section no. 35, North Ellwood-Coal Oil Point area across the Santa Barbara Channel to the north coast of Santa Cruz Island: American Association of Petroleum Geologists, Pacific Section, Publication CS 35, 1 sheet.

Reid, J.A., Reid, J.M., Jenkins, C.J., Zimmerman, M., Williams, S.J., and Field, M.E., 2006, usSEABED -Pacific Coast (California, Oregon, Washington) offshore surficial-sediment data release: U.S. Geological Survey Data Series 182, available at http://pubs.usgs.gov/ds/2006/182/. 
Schoell, M., McCaffrey, M.A., Fago, F.J., and Moldowan, J.M., 1992, Carbon isotopic compositions of 28,30-bisnorhopanes and other biological markers in a Monterey crude oil: Geochimica et Cosmochima Acta, v. 56, p. 1,391-1,399.

Slater, R.A., Gorsline, D.S., Kolpack, R.L., and Shiller, G.I., 2002, Post-glacial sediments of the California shelf from Cape San Martin to the US-Mexico border: Quaternary International, v. 92, p. 45-61.

Sliter, R.W., Triezenberg, P.J., Hart, P.E., Draut, A.E., Normark, W.R., and Conrad, J.E., 2008, Highresolution chirp and mini-sparker seismic reflection data from the southern California continental shelf-Gaviota to Mugu Canyon: U.S. Geological Survey Open-File Report 2008-1246, available at http://pubs.usgs.gov/of/2008/1246/.

Sommerfield, C.R., Lee, H.J., and Normark, W.R., 2009, Postglacial sedimentary record of the southern California continental shelf and slope, Point Conception to Dana Point, in Lee, H.J., and Normark, W.R., eds., Earth science in the urban ocean-The Southern California Continental Borderland: Geological Society of America Special Paper 454, p. 89-116.

Soutar, A., and Crill, P.A., 1977, Sedimentation and climatic patterns in the Santa Barbara Basin during the 19th and 20th centuries: American Association of Petroleum Geologists Bulletin, v. 88, p. 1,161-1,172.

Southern California Earthquake Data Center, 2010, Southern California Earthquake Catalog: Southern California Earthquake Data Center database, accessed April 5, 2011, at http://www.data.scec.org/ eq-catalogs/index.html.

Stanford, J.D., Hemingway, R., Rohling, E.J., Challenor, P.G., Medina-Elizalde, M., and Lester, A.J., 2011, Sea-level probability for the last deglaciation-A statistical analysis of far-field records: Global and Planetary Change, v. 79, p. 193-203, doi:10.1016/j.gloplacha.2010.11.002.

Sylvester, A.G., 2001, Catalog of Santa Barbara earthquakes-1800 to 1960: University of California, Santa Barbara, database, available at http://projects.crustal.ucsb.edu/sb_eqs/SBEQCatlog/ SBEQCATINTRO.html.

Sylvester, A.G., Smith, S.S., and Scholz, C.H., 1970, Earthquake swarm in the Santa Barbara Channel, California, 1968: Bulletin of the Seismological Society of America, v. 60, p. 1,047-1,060.

Tissot, B.N., Yoklavich, M.M., Love, M.S., York, K., and Amend, M., 2006, Benthic invertebrates that form habitat on deep banks off southern California, with special reference to deep sea coral: Fishery Bulletin, v. 104, p. 167-181.

Trecker, M.A., Gurrola, L.D., and Keller, E.A., 1998, Oxygen-isotope correlation of marine terraces and uplift of the Mesa Hills, Santa Barbara, California, USA, in Stewart, I.S., and Vita-Finzi, eds., Coastal tectonics: Geological Society, London, Special Publications, v. 146, p. 57-69.

U.S. Geological Survey, 2009, National Archive of Marine Seismic Surveys: U.S. Geological Survey database, accessed April 5, 2011, at http://walrus.wr.usgs.gov/NAMSS/.

Warrick, J.A., and Farnsworth, K.L., 2009, Sources of sediment to the coastal waters of the Southern California Bight, in Lee, H.J., and Normark, W.R., eds., Earth science in the urban ocean-The Southern California Continental Borderland: Geological Society of America Special Paper 454, p. 39-52.

Washburn, L.C., Johnson, L., Gotschalk, C., and Egland, E.T., 2001, A gas-capture buoy for measuring bubbling gas flux in oceans and lakes: Journal of Atmospheric and Oceanic Technology, v. 18, p. 1,411-1,420.

Weber, K.M., List, J.H., and Morgan, K.L., 2005, An operational Mean High Water datum for determination of shoreline position from topographic lidar data: U.S. Geological Survey Open-File Report 2005-1027, available at http://pubs.usgs.gov/of/2005/1027/.

Wentworth, C.K., 1922, A scale of grade and class terms for clastic sediments: Journal of Geology, v. 30, p. 377-392. 
Wilkinson, E.R., 1971, California offshore oil and gas seeps, in California oil fields-Summary of operations: California Division of Oil and Gas, v. 57, p. 5-28.

Wilkinson, E.R., 1972, California offshore oil and gas seeps: California Division of Oil and Gas, 16 p.

Williams, L.A., 1984, Subtidal stromatolites in Monterey Formation and other organic-rich rocks as suggested contributors to petroleum formation: American Association of Petroleum Geologists Bulletin, v. 68, p. 1,879-1,893.

Wills, C.J., Weldon, R.J., II, and Bryant, W.A., 2008, Appendix A-California fault parameters for the National Seismic Hazard Maps and Working Group on California Earthquake Probabilities 2007: U.S. Geological Survey Open-File Report 2007-1437A, 48 p., available at http://pubs.usgs.gov/of/ 2007/1437/a/.

Wong, F.L., Phillips, E.L., Johnson, S.Y, and Sliter, R.W., 2012, Modeling of depth to base of Last Glacial Maximum and seafloor sediment thickness for the California State Waters Map Series, eastern Santa Barbara Channel, California: U.S. Geological Survey Open-File Report 2012-1161, 16 p., available at http://pubs.usgs.gov/of/2012/1161/.

Xu, J.P., and Noble, M.A., 2009, Variability of the southern California wave climate and implications for sediment transport, in Lee, H.J., and Normark, W.R., eds., Earth science in the urban ocean-The Southern California Continental Borderland: Geological Society of America Special Paper 454, p. 171-192. 